UNIVERSIDADE DE SÃO PAULO

FACULDADE DE ECONOMIA, ADMINISTRAÇÃO E CONTABILIDADE

DEPARTAMENTO DE CONTABILIDADE E ATUÁRIA

PROGRAMA DE PÓS-GRADUAÇÃO EM CONTROLADORIA E CONTABILIDADE

DENIS LIMA E ALVES

Estrutura de Capital de Multinacionais no Brasil após o Estabelecimento de Regras para Thin Capitalization: um experimento natural 
Prof. Dr. Marco Antonio Zago

Reitor da Universidade de São Paulo

Prof. Dr. Adalberto Américo Fischmann

Diretor da Faculdade de Economia, Administração e Contabilidade

Prof. Dr. Ariovaldo, dos Santos

Chefe do Departamento de Contabilidade e Atuária

Prof. Dr. Lucas Ayres Barreira de Campos Barros

Coordenador do Programa de Pós-Graduação em Controladoria e Contabilidade. 
DENIS LIMA E ALVES

\section{Estrutura de Capital de Multinacionais no Brasil após o Estabelecimento de Regras para Thin Capitalization: um experimento natural}

\section{Versão Corrigida}

(versão original encontra-se disponível na Faculdade de Economia, Administração e Contabilidade)

Tese apresentada ao Programa de Pós-Graduação em Controladoria e Contabilidade da Faculdade Economia, Administração e Contabilidade da Universidade de São Paulo, como requisito parcial para obtenção do título de Doutor em Ciências.

Orientador: Prof. Dr. Edson Luiz Riccio

SÃO PAULO

2018 
Autorizo a reprodução e divulgação total ou parcial deste trabalho, por qualquer meio convencional ou eletrônico, para fins de estudo e pesquisa, desde que citada a fonte.

Alves, Denis Lima e

Estrutura de capital de multinacionais no Brasil após o estabelecimento de regras para thin capitalization: um experimento natural / Denis Lima e Alves. - São Paulo, 2018.

$131 \mathrm{p}$.

Tese (Doutorado) - Universidade de São Paulo, 2018.

Orientador: Edson Luiz Riccio.

1. Imposto de renda 2. Subcapitalização 3. Experimento natural 4. Diferenças em diferenças I. Universidade de São Paulo. Faculdade de Economia, Administração e Contabilidade. II. Título.

CDD - 336.242 
Nome: Alves, Denis Lima e

Título: Estrutura de Capital de Multinacionais no Brasil após o Estabelecimento de Regras para Thin Capitalization: um experimento natural

Tese apresentada ao Programa de Pós-Graduação em Controladoria e Contabilidade da Faculdade Economia, Administração e Contabilidade da Universidade de São Paulo, como requisito parcial para obtenção do título de Doutor em Ciências.

Aprovado em:

Banca Examinadora

Prof. Dr.

Instituição:

Julgamento:

Prof. Dr.

Instituição:

Julgamento:

Prof. Dr.

Instituição:

Julgamento: 

Aos meus pais. À Mirjam. 



\section{AGRADECIMENTOS}

Agradeço à Fundação de Amparo à Pesquisa do Estado de São Paulo - FAPESP pela concessão da bolsa de doutorado que financiou parcialmente este projeto por meio do processo de número 2015/11547-6 e de mesmo título que esta tese. As opiniões, hipóteses e conclusões ou recomendações expressas neste material são de responsabilidade do autor e não necessariamente refletem a visão da FAPESP. Este trabalho também foi conduzido com o suporte financeiro da Coordenação de Aperfeiçoamento de Pessoal de Nível Superior - CAPES, por meio do processo de número 99999.000004/2016-02, em parceria com o Deutscher Akademischer Austauschdienst - DAAD, órgão de fomento alemão, que concedeu a bolsa "sanduíche" para financiamento de atividades no exterior. Ter sido agraciado com suporte financeiro das duas maiores instituições de fomento do país e uma alemã é uma honra, um privilégio, incentivo e reconhecimento profissional significativo.

Esta página de agradecimentos consiste de uma tímida tentativa de reconhecer o relevante papel que algumas pessoas desempenharam durante os últimos anos e, nem de longe, é completa. Começo, claro, por meus pais, por razões óbvias. Meu orientador, professor Dr. Edson Luiz Riccio, pela tranquilidade e experiência compartilhadas. Colegas de curso e amigos que encontrei durante o curso e que me proporcionaram momentos e experiências tanto agradáveis quanto úteis. Sou muito grato a Ludmila, Wender, Suave, Carol, os "Danieis", Suzana, Franciele, Fernanda Kreuzberg.

Agradeço ao professor Dr. Lucas Barros por seu amigável e constante suporte com análises de dados e teoria. Suporte sem o qual eu não estaria aqui hoje, literalmente. Agradeço ao professor Dr. Guerreiro por ter simplesmente possibilitado a maior experiência de vida, pessoal e profissional, que já tive. Agradeço ao Eduardo Flores, que me forneceu a inspiração inicial para o tema de minha tese e sempre debateu comigo, de forma livre e espontânea, novas ideias a respeito de qualquer coisa que lhe questionasse. À professora Dra Sílvia Casa Nova e ao professor Dr. Andson de Aguiar, por proverem suporte calcado de ética e comprometimento, por contribuírem generosamente para o curso e por serem tão amigáveis nos corredores da FEA.

An meinen Freunden in Deutschland: professor Professor Dr. Christoph Watrin, Falko Weiß, Stephan Burggraef, Alexander Brune, Dr. Adrian Kubata, Robert Leukefeld, Nils Linnemann, Fabian Schmal, Katharina Schulte, Veit Hölzel, Dr. Martin Thomsen und Fabian Riegler. Sie haben meine Tage in Deutschland so viel gemütlicher und glücklicher gemacht. Es ist sehr einfach zu sehen, dass mein Deutsch nur ein bisschen besser geworden ist, aber die Golffähigkeiten... dankeschön! Die Erfahrung in Deutschland hat zu meiner beruflichen Entwicklung als internationaler Forscher viel beigetragen.

Finalmente, agradeço a Deus por ter, exatamente neste momento de muito trabalho e pouquíssimo tempo disponível, colocado em minha vida a melhor pessoa que já tive o prazer de conhecer e, além disso, tê-la feito a companhia que terei para o resto da vida: minha esposa. 

"I was gratified to be able to answer promptly, and I did. I said I didn't know." Mark Twain

"Any fool can know. The point is to understand." Albert Einstein 



\section{RESUMO}

ALVES, D. L. (2018). Estrutura de Capital de Multinacionais no Brasil após o Estabelecimento de Regras para Thin Capitalization: um experimento natural (Tese de Doutorado). Faculdade de Economia, Administração e Contabilidade, Universidade de São Paulo, São Paulo.

Este trabalho emprega métodos quantitativos a dados de Demonstrações Financeiras para avaliar a existência de relação de causalidade entre a Lei 12.249 de 11 de junho de 2010, que institui normas de subcapitalização no Brasil, e a estrutura de capital de empresas brasileiras que possuem partes vinculadas no exterior. Esta lei estabeleceu limites ao endividamento oriundo de tais partes vinculadas para que os respectivos juros pagos sejam considerados dedutíveis para fins da apuração de tributos sobre o lucro e foi usada como intervenção exógena na análise proposta. Os dados são oriundos de empresas fechadas e de empresas públicas, coletados manualmente, em jornais publicamente disponíveis, e na base de dados Economatica $^{\circledR}$ e foi obtida uma amostra inicial de 2,070 observações. Após exclusão daquelas com Patrimônio Líquido negativo, restaram 1,816 observações em um painel não balanceado, subamostra usada para estimação com o método principal de investigação deste trabalho, que foi o de Diferenças-em-diferenças (DD). Neste, a variável dependente consistiu da razão entre dívida onerosa total e Ativo Total, observados anualmente no período compreendido entre o ano de 2006 e ano de 2014. Este método foi estimado por OLS seus resultados foram complementados com o pareamento de observações por meio de quatro procedimentos de propensity score matching (PSM), one-to-one, nearest neighbour, radius e kernel, em que a alavancagem consistiu da diferença, observada entre o ano de 2011 e o ano de 2009 , dos valores da variável resposta descrita anteriormente. Para estimação por meio de matching, foram excluídas observações de empresas que variaram a composição societária ao longo do período de forma a possuir partes vinculadas estrangeiras em determinado momento e não possuí-las mais tarde e também foram excluídas aquelas empresas que não possuem observações durante todo o período avaliado, obtendo-se um painel balanceado com 114 empresas e 1,026 observações. O propensity score obtido foi ainda empregado para ponderar as observações no modelo previamente estimado com o método DD. As variáveis de controle empregadas tanto no DD quanto na estimação do propensity score consistiram dos valores de Ativo Imobilizado, Vendas Líquidas, Lucro Bruto e Patrimônio Líquido, obsevados anualmente e dividido pelo Ativo Total. Os resultados obtidos não foram significantes aos níveis convencionais de confiança, apontando para possível redução da relação entre dívida total e Ativo Total das empresas do grupo tratamento em valores que variaram entre $4.17 \%$ e $0.5 \%$ em termos de Ativo Total, dependendo do método e modelo estimados. Observa-se que tanto a variável resposta quanto o endividamento oneroso total das empresas de ambos os grupos parecem ter aumentado durante o período investigado, mas a variável resposta, aparentemente, já apresentava crescimento menos acentuado nas empresas do grupo tratamento antes do advento da lei, não sendo possível concluir que esta seja a causa da tendência de decréscimo da relação entre dívida e Ativo Total no grupo de empresas que possuem partes vinculadas estrangeiras. Ressalvadas as limitações do estudo, conclui-se que a lei não teve efeito sobre o endividamento total e, portanto, sem efeitos sobre a arrecadação de tributos sobre o lucro destas empresas.

Palavras-chave: experimento natural, diferenças em diferenças, subcapitalização, partes vinculadas estrangeiras, propensity score matching, Lei 12249. 



\begin{abstract}
ALVES, D. L. (2018). Capital Structure of Multinationals in Brazil After the Establishment of Thin Capitalization Rules: a Natural Experiment (Tese de Doutorado). Faculdade de Economia, Administração e Contabilidade, Universidade de São Paulo, São Paulo.
\end{abstract}

This work applies quantitative methods to data from Financial Statements to assess the existence of a causal relationship between the Law 12,249 of June 11, 2010, which establishes thin capitalization rules in Brazil, and the capital structure of Brazilian companies that keep foreign related parties. This law established limits to the tax deductibility arising from interest payments to such related parties and was here employed as a source of exogenous variation to perform the proposed analysis. The data came from private and public companies, were manually collected, from publicly available newspapers, and obtained from the Economatica database. An initial sample of 2,070 observations was obtained. After the exclusion of those with negative Equity, there were 1,816 observations composing an unbalanced panel, subsample which was used for estimation with the main research method of this investigation, which was the Differences-in-differences (DD) method. A dependent variable consisted of the ratio between total costly debt and Total Asset, observed annually in the period between the years 2006 and 2014. This method has been estimated by OLS and its results were complemented with the pairing of companies by means of four matching methods: One-to-one, nearest neighbour, radius, and kernel, where the response variable consisted of the difference between the dependent variable's values observed in the years 2011 and 2009. To estimate the laws' effects by means of matching procedures, data from companies that showed variation at the societal composition in such a way that led them to have foreign related parties in less than the whole period and from those companies that do not have data throughout the whole period evaluated were excluded, and a balanced panel with 114 companies and 1,026 observations remained. Yet again, the obtained propensity score was applied as weight for another OLS DD estimation. Control variables consisted of the values of Fixed Assets, Net Sales, Gross Profits and Shareholders' Equity, reported annually and divided by Total Assets. The results obtained were not significant at any conventional confidence levels, nevertheless pointing to a reduction of the treatment group companies' ratio between debt and Total Assets which varied between $4.17 \%$ and $0.5 \%$ of Total Assets, depending on the estimated method and model. It appears that the companies' both response variable and total costly indebtedness increased during the period analysed, but the response variable seems to have already presented a less pronounced growth in the treatment group's companies before the existence of the law, therefore making it not possible to conclude that this legislation piece is the cause of the downward trend in the ratio between debt and Total Assets of companies that keep foreign related parties. Subject to this study's limitations, it is possible to conclude that the law had no effect on total indebtedness and, therefore, had no effect on profit taxes base erosion regarding this group of companies.

Keywords: natural experiment, differences-in-differences, thin capitalization, foreign related parties, propensity score matching, Law 12249. 



\section{LISTA DE TABELAS}

Tabela 1 - Evolução das contas financeiras do Balanço de Pagamentos ................................. 27

Tabela 2 - Variáveis de controle empregadas no estudo...................................................... 75

Tabela 3 - Valores médios e medianos das variáveis observadas em ambos os grupos e a cada ano.

Tabela 4. Coeficientes e erros-padrão da diferença dos valores médios entre os grupos do estudo

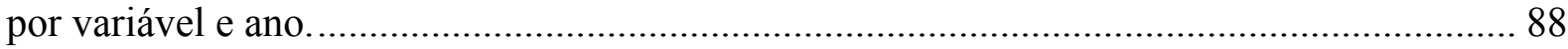

Tabela 5 - Variação temporal em função de grupo.............................................................. 91

Tabela 6 - Coeficientes e estatísticas estimadas por meio de OLS...................................... 92

Tabela 7 - Coeficientes e estatísticas estimadas por meio de OLS e Efeitos Fixos................. 93

Tabela 8 - Estimação após pareamento por propensity score, por método.............................. 94

Tabela 9 - Efeito estimado da lei sobre empresas que possuem partes vinculadas estrangeiras, por método de estimação.

Tabela 10 - Efeito estimado da lei sobre variável resposta obtida considerando o capital disponível.

Tabela 11 - Resultados do matching considerando dívida financeira onerosa por capital disponível. 



\section{LISTA DE EQUAÇÕES}

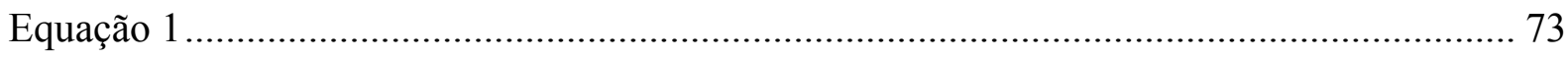

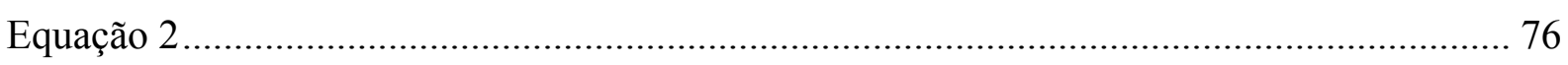

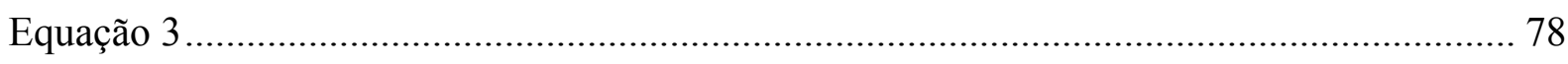

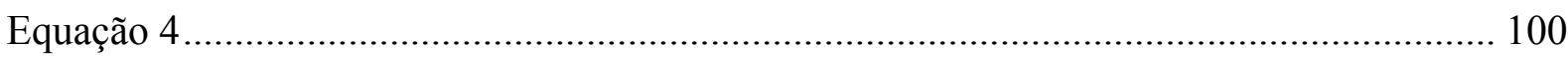

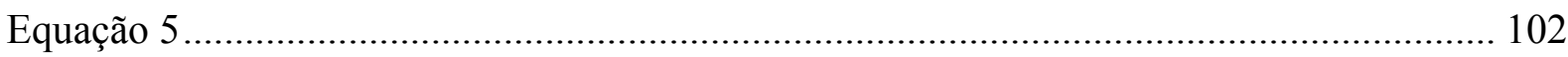





\section{LISTA DE QUADROS}

Quadro 1 - Quantis das variáveis analisadas em função de quantis da distribuição normal, grupo tratamento. 95

Quadro 2 - Quantis das variáveis analisadas em função de quantis da distribuição normal, grupo controle. 96

Quadro 3 - Boxplot da variável resposta das empresas analisadas. 97

Quadro 4 - Valores médios anuais por grupo de matching: verificação de tendências. 98

Quadro 5 - Teste placebo por método de matching. 99

Quadro 6 - Log natural dos valores médios anuais da dívida absoluta das empresas em comparação com a razão entre esta dívida e o capital total disponível. 

SEÇÃO I - INTRODUÇÃO ................................................................................................... 25

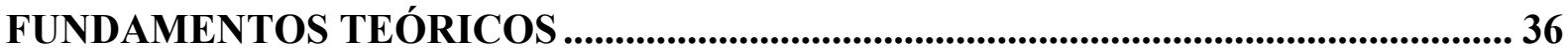

1. ESTRUTURA DE CAPITAL ...................................................................... 36

2. SUBCAPITALIZAÇÃO (THIN CAPITALIZATION) E A MOBILIDADE DE RECURSOS FINANCEIROS

3. IMPACTOS ESPERADOS COM A ENTRADA DE IED E EIC NA ECONOMIA DE UMA NAÇÃO......................................................................................... 47

SEÇÃO II - CONTEXTOS LEGAL, TRIBUTÁRIO E CONTÁBIL DAS REGRAS BRASILEIRAS DE SUBCAPITALIZAÇÃO E AS REGRAS EM OUTROS PAÍSES . 50

1. CONTEXTO LEGAL BRASILEIRO ........................................................ 50

2. AS NORMAS EM OUTROS PAÍSES .......................................................... 60

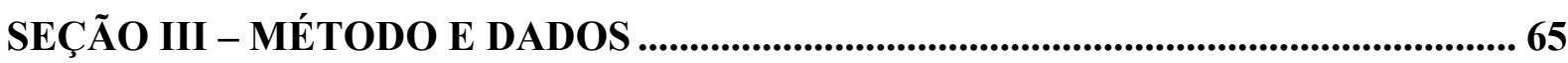

1. O PROBLEMA DE PESQUISA .................................................................... 65

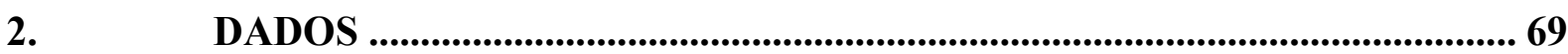

3. DESCRIÇÃO DAS VARIÁVEIS ........................................................... 70

4. ESTRATÉGIA DE IDENTIFICAÇÃO................................................... 71

SEÇÃO IV - ESTATÍSTICAS DESCRITIVAS.............................................................. 81

SEÇÃO V - RESULTADOS E ANÁLISE ................................................................... 89

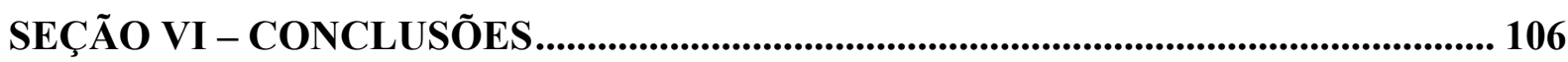

SEÇÃO VII - REFERÊNCIAS................................................................................... 113

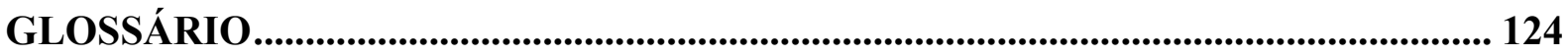

ANEXO A - NOTA DE AUDITORIA INDEPENDENTE................................................. 125

ANEXO B - LISTA DAS EMPRESAS USADAS NO ESTUDO. ....................................... 126

APÊNDICE I - ESTATÍSTICAS COMPARATIVAS: EMPRESAS COM

PATRIMÔNIO LÍQUIDO MENOR DO QUE ZERO .................................................. 128

APÊNDICE II - VALORES MÉDIOS E MEDIANOS DAS VARIÁVEIS

EXPLICATIVAS, ANTES E APÓS A LEI.............................................................. 130

APÊNDICE III - COEFICIENTES E ERROS-PADRÃO DA DIFERENÇA ENTRE OS GRUPOS POR VARIÁVEL E POR PERÍODO. ........................................................... 131

APÊNDICE IV - GRÁFICO COM VALORES MEDIANOS DA VARIÁVEL

DEPENDENTE POR ANO E GRUPO. 



\section{Estrutura de Capital de Multinacionais no Brasil após o Estabelecimento de Regras para Thin Capitalization: um experimento natural}

\section{Seção I - Introdução}

Para contribuir para a formação do conhecimento acerca da interação entre tributos sobre o lucro e o grau de endividamento de empresas, este estudo investiga o efeito da Lei 12.249 de 11 junho de 2010, que estabeleceu as regras brasileiras de subcapitalização (thin capitalization), sobre a estrutura de capital de empresas brasileiras que possuem partes vinculadas estrangeiras em relação àquelas que não possuem. Diz-se que uma companhia se encontra subcapitalizada quando é financiada por uma proporção alta de dívida em relação a seu Patrimônio Líquido. Por possuírem partes relacionadas domiciliadas fora do país em que se encontram, estas entidades podem contar, em relação a empresas que não as possuem, com a vantagem de obter empréstimos dentro de seu grupo econômico, auferindo, além dos benefícios tributários relativos à dedução dos juros pagos da base de cálculo dos tributos sobre renda, outras vantagens relacionadas às condições dos contratos, como taxas inferiores, prazos maiores e inexistência de garantias. Portanto, partindo de uma intervenção que elimina parcialmente a vantagem tributária de empréstimos desta natureza, buscam-se evidências de alterações na estrutura de capital de empresas sujeitas aos efeitos da política tributária em questão.

A comparação entre dois grupos de empresas, antes e após uma intervenção dessa natureza, pode contribuir para o entendimento acerca da sensibilidade que políticas de financiamento possuem em relação a tributos. Portanto, o fenômeno de interesse consiste de alterações relativas na estrutura de capital de empresas brasileiras como consequência da lei que regula a subcapitalização neste país. A estratégia de identificação constitui-se de um "quasi experimento" (Doidge \& Dyck, 2015) ou experimento natural (Wooldridge, 2002, p. 410), representado por uma intervenção potencialmente exógena por meio de uma norma tributária brasileira e que pode afetar políticas de financiamento das empresas. Ao confrontar as tendências do endividamento dos grupos antes e após o advento da lei, garantindo a comparabilidade dos grupos por meio de verificação objetiva dessas tendências antes da intervenção exógena, podem-se verificar as semelhanças e diferenças entre estas tendências, buscando descrever a relação de causalidade entre o advento da lei e o endividamento das empresas.

Para fins deste estudo, a principal diferença entre os grupos é o fato de que o grupo dito "tratamento" constitui-se de empresas que possuem partes vinculadas localizadas no exterior, enquanto o grupo "controle" não as possui. Esta situação, necessária, embora não suficiente 
para que a lei produza efeitos, cria condições que favorecem a entrada de recursos financeiros no formato de empréstimos intercompanhia. De fato, dados do Banco Central do Brasil (BCB) mostram que os valores de empréstimos intercompanhia (EIC) ${ }^{1}$ da conta Investimento Brasileiro Direto (IBD) do Balanço de Pagamentos apontam para um crescimento de $37 \%$ a.a. em créditos líquidos, atingindo a cifra de 23,1 bilhões de dólares no ano de 2014. Este valor foi transferido do exterior para unidades operacionais no Brasil por meio de operações de empréstimos dentro do mesmo grupo de empresas. No entanto, uma visão analítica desta conta evidencia que os ingressos de recursos intercompanhia, oriundos de filiais no exterior e com destino às suas matrizes no Brasil, cresceram, isoladamente, 188,44\% a.a., atingindo 27,8 bilhões de dólares no mesmo ano. Ainda, o ingresso de recursos oriundos de empresas situadas no exterior rumo a suas partes no Brasil, que se verifica na conta Investimento Estrangeiro Direto (IED), apresentou até o final do ano de 2014, crescimento de $18.3 \%$, como se verifica na Tabela 1. Este crescimento foi inferior à taxa referente aos recursos originários em filiais estrangeiras, mas atingiu a cifra de 36,08 bilhões de dólares em 2014, tendo, em função do valor transacionado, um efeito tributário potencial superior àquele observado na conta de IBD. Os valores incluídos na conta EIC são compostos de contratos de empréstimos realizados entre as matrizes no Brasil e suas filiais no exterior, no caso dos IBD, e por contratos realizados entre matrizes no exterior a suas filiais no Brasil, no caso dos IED. A Tabela 1 ilustra os valores ingressantes de EIC de ambas situações no período de 2006 a 2014. É possível visualizar, portanto, uma tendência de crescimento do total de recursos onerosos que adentram o país com destino às empresas situadas no Brasil, ao observar as duas entradas intituladas "Ingresso". Tais recursos são onerosos e geram despesas de juros, cujos pagamentos são dedutíveis da base de cálculo do Imposto de Renda (IR) e Contribuição Social sobre o Lucro Líquido (CSLL ou contribuição), erodindo, em tese, a base tributária e afetando o governo e a sociedade. Como resultado, o governo brasileiro, seguindo prática recorrente no âmbito internacional, emitiu norma para regulamentação de empréstimos intercompanhia. Pouco se sabe sobre os reais impactos sociais e econômicos do crescente ingresso de recursos desta natureza, embora a literatura corrente forneça exemplos de avaliação dos impactos da entrada de capital estrangeiro, IED, sobre o crescimento econômico sem, no entanto, apresentar uma análise em separado dos efeitos dos EIC em relação às outras formas de ingresso de recursos.

\footnotetext{
1 Operações de empréstimos em moeda contraídas por empresas do setor privado não financeiro, inclusive a Petrobras, junto a entidades privadas estrangeiras não financeiras (B. C. do Brasil, 2011).
} 
Tabela 1 - Evolução das contas financeiras do Balanço de Pagamentos*

\begin{tabular}{|c|c|c|c|c|c|c|c|c|c|c|}
\hline Conta & 2006 & 2007 & 2008 & 2009 & 2010 & 2011 & 2012 & 2013 & 2014 & Crescimento \\
\hline Investimento brasileiro direto & $-28,202.5$ & $-7,066.7$ & $-20,457.1$ & $10,084.2$ & $-11,587.6$ & $1,029.0$ & $2,821.4$ & $3,495.1$ & $3,540.1$ & $1.5 \%$ \\
\hline Empréstimo intercompanhia & $-4,789.0$ & $3,024.7$ & $-6,598.0$ & $14,629.5$ & $15,194.7$ & $20,562.5$ & $10,376.8$ & $18,255.6$ & $23,095.7$ & $24.6 \%$ \\
\hline Filial no exterior a matriz no Brasil & -16.0 & $8,847.7$ & $5,751.1$ & $4,510.3$ & $4,793.3$ & $6,106.5$ & $10,456.1$ & $16,976.1$ & $24,245.8$ & $149.8 \%$ \\
\hline Ingresso & 5.8 & $8,849.6$ & $6,314.8$ & $6,085.0$ & $8,419.6$ & $8,512.3$ & $14,090.1$ & $21,209.5$ & $27,771.9$ & $188.4 \%$ \\
\hline Investimento estrangeiro direto & $18,822.2$ & $34,584.9$ & $45,058.2$ & $25,948.6$ & $48,506.5$ & $66,660.1$ & $65,271.9$ & $63,995.9$ & $62,494.8$ & $11.1 \%$ \\
\hline Empréstimo intercompanhia & $3,449.6$ & $8,510.5$ & $14,994.1$ & $6,042.2$ & $8,389.8$ & $11,877.7$ & $12,434.1$ & $22,351.5$ & $15,192.0$ & $16.5 \%$ \\
\hline Matriz no exterior a filial no Brasil & $4,061.5$ & $9,657.3$ & $14,901.3$ & $7,064.3$ & $8,434.6$ & $10,649.7$ & $12,816.8$ & $22,222.6$ & $14,731.0$ & $12.8 \%$ \\
\hline Ingresso & $9,410.1$ & $15,202.7$ & $25,337.8$ & $20,449.0$ & $22,402.0$ & $28,804.0$ & $22,493.9$ & $35,481.3$ & $36,078.6$ & $13.9 \%$ \\
\hline
\end{tabular}

Notas: "Crescimento" é a Taxa Anual Composta de Crescimento.

Fonte: Banco Central do Brasil, 2015.

* Em milhões de dólares americanos. 
Estudos sobre medidas dessa natureza têm evidenciado a efetividade das normas, o que se visualiza principalmente na modificação das estruturas de financiamento de empresas a elas sujeitas.

Conforme teoria (Modigliani \& Miller, 1963), a presença de tributos sobre o lucro permite que se obtenham vantagens com dívidas em função da dedutibilidade de juros incorridos. Mais recentemente, Graham (2013) relata corpo de evidências empíricas ao sugerir que a dedutibilidade de juros para fins de imposto sobre a renda é um fator importante na determinação de políticas de financiamento, apesar de secundário. Portanto, é possível que o estabelecimento de regras que restringem a obtenção de benefícios oriundos da contratação de dívidas tenha efeitos observáveis na formação da estrutura de capital em determinadas situações, dado que extingue parcialmente o incentivo para manutenção de uma parte da dívida.

Neste texto, considera-se "excessiva" a parcela de EIC que excede os limites estabelecidos em lei para a dedutibilidade dos juros incorridos, sendo indedutíveis os juros referentes a essa parcela. A partir de uma perspectiva racional, a administração de uma empresa contrata dívidas se os custos destas, tanto os financeiros quanto os não financeiros, forem inferiores aos benefícios. Dentre as razões pelas quais uma companhia manteria em seu Passivo uma parcela de dívida que deixa de oferecer benefícios tributários, pode ser encontrada a obtenção de benefícios financeiros e não financeiros, geralmente relacionados a custos de fontes alternativas de endividamento, necessidade de garantias em empréstimos ou elevados custos para obtenção de recursos em bolsa. Tais condições pertencem ao conjunto de características inerentes a cada empresa e, em parte, não podem ser observados a partir de demonstrações financeiras.

Controladas outras causas externas que podem influenciar e alterar para baixo o endividamento total de uma empresa, a redução dos empréstimos intercompanhia após restrição à dedutibilidade dos juros pode ser entendida como elemento pertencente ao conjunto de condições que causam essa alteração. Em especial, observando-se uma redução do endividamento total das empresas do grupo "tratamento" após o advento da lei, é possível que tal redução seja efeito do fato de que os EIC não mais oferecem os mesmos benefícios tributários. Portanto, dado o contexto temporal da análise, em que a restrição ao benefício tributário da dívida desempenha papel relevante, este tipo de endividamento seria parcial ou totalmente eliminado do Passivo como efeito da lei. Por outro lado, a manutenção de endividamento interno, mesmo sem o benefício tributário pode se dar em função do menor montante que outros custos representam, como a necessidade de garantias reais. Embora não se 
conheça, ainda, a relevância de empréstimos intercompanhia para empresas instaladas no Brasil, a literatura apresenta evidências significantes de que algumas empresas estão dispostas a arcar com altos custos de mudanças em políticas como distribuição de resultados, liquidez e investimentos para obter tratamento tributário diferenciado (Doidge \& Dyck, 2015), o que evidencia a importância do tema. Verificar o grau de ajustamento das decisões concernentes à estrutura de capital em ambientes restritivos de dedutibilidade pode contribuir para um melhor entendimento dos determinantes da relação entre tributos e decisões de financiamento, ou seja, estrutura de capital. Este grau de ajustamento pode ser verificado também na condição de ausência de alteração do endividamento total, pelas razões acima mencionadas. No caso de haver substituição do EIC que não mais oferece beneficio tributário por empréstimo externo, o endividamento total permanece o mesmo, provendo o mesmo benefício. Poucos estudos, no entanto, esclarecem a possibilidade de se substituir EIC por empréstimo externo, mas há indícios na literatura de que essa relação não depende apenas de variáveis internas ao grupo empresarial, como também de características dos mercados de capitais e financeiro de cada país. Por outro lado, caso o benefício tributário seja a principal razão para a existência do EIC, o ajustamento das decisões relativas à estrutura de capital poderá ocorrer no sentido da redução do endividamento total das multinacionais, em decorrência da diminuição ou eliminação do EIC sem substituição. O fato é que, tanto na substituição dos EIC por empréstimos externos quanto na redução do endividamento geral, o legislador não terá obtido sucesso na elaboração da lei, pois não haverá aumento na arrecadação. Portanto, é possível que esta lei não produza os benefícios esperados, sendo inefetiva, embora as empresas sejam levadas a alterar suas políticas internacionais de planejamento tributário.

Em face da relação existente entre estrutura de capital e tributos sobre a renda, apregoada por Modigliani e Miller (1963), foi comparada a evolução diferencial da estrutura de capital de dois grupos de empresas: empresas que possuem partes relacionadas estrangeiro e empresas que não possuem. A existência de partes vinculadas estrangeiras confere, em relação a empresas que não as possuem, a prerrogativa de escolher o país em que alocam seus recursos financeiros, após ponderação de quaisquer critérios que julgarem relevantes, mas que são, em geral, distintos entre os países em que se instalam. Ainda, confere a possibilidade de transferir lucros, bem como transferir dívida com o intuito de obter benefício tributário e a liberdade de, a qualquer momento, alterar as políticas ora praticadas com relação a essas decisões. Por meio da comparação entre estes dois grupos, portanto, e a partir da verificação do diferencial na sensibilidade da estrutura de capital à restrição tributária avaliada, espera-se identificar os 
efeitos de uma intervenção que, ao restringir diretamente uma prática usual e endêmica do grupo de empresas que possuem tais prerrogativas, tem o potencial para provocar mudanças nas políticas de financiamento deste grupo. A mensuração da resposta diferencial em suas estruturas de capital possibilitará que se contribua para a formação do corpo de evidências empíricas que concernem os estudos teóricos existentes, bem como lançar luz adicional sobre os pressupostos teóricos que explicam a relação entre tributos e estrutura de capital.

Teses acerca dos determinantes da estrutura de capital e eficiência de mercado, em especial naquilo que tange à influência que possuem os tributos sobre a renda nestes fenômenos, fornecem a teoria à luz da qual se realiza esta pesquisa. Por exemplo, no contexto de mercados perfeitos, não existem razões para supor que as taxas praticadas nos contratos de dívida externa são as diferentes daquelas praticadas no mercado de dívida interna, embora parcialmente determinadas por lei no Brasil, ou que este mercado aloca eficientemente seus recursos disponíveis. De fato, existem diferenças na forma como empresas que possuem partes vinculadas estrangeiras lidam com políticas de financiamento, em relação àquelas que não as possuem (Aghion \& Bolton, 1992). Ainda, tributos influenciam também o ambiente dos contratos de crédito intercompanhia, proporcionando tax shields. É viável propor que os envolvidos nestes contratos possuem informações inacessíveis a indivíduos externos à transação, em maior ou menor grau que suas contrapartes pertencentes ao mesmo grupo, sugerindo a existência de custos de assimetria de informação nos mercados internos.

Além dos aspectos teóricos concernentes a custos de agência e assimetria informacional e a seus efeitos na determinação de estruturas de capital, outros custos de dívida são abordados nas pesquisas sobre estrutura de capital e ponderados contra o benefício tributário do endividamento. Por exemplo, verificou-se que endividamento elevado acarreta custos de falência (Kraus \& Litzenberger, 1973) e de sub-investimento (Myers, 1977), embora existam evidências que sugerem que a dívida intercompanhia tem sido empregada com o objetivo de, ao contrário, reduzir custos de sub-investimento e evitar custos de agência por meio do comprometimento do fluxo de caixa livre das subsidiárias. Embora a diferenciação definitiva entre como funcionam mercados internos e mercados externos de capitais ainda precise avançar na descrição de seu funcionamento, o fato de o capital ser provido por proprietários da parte que o recebe tem consequências institucionais para o grupo empresarial e pode determinar a eficiência das decisões de alocação de capital (Gertner, Scharfstein, \& Stein, 1994).

No que tange à contribuição ao corpo de evidências empíricas que suporta as teorias correlatas, este estudo investigou o ajuste do mecanismo de determinação da estrutura de capital 
das empresas avaliadas a determinados pressupostos teóricos, em especial, à teoria do tradeoff. Considerando a análise custo-benefício de dívidas, restrições geradas por regras tributárias têm potencial para dar origem a alterações nos padrões desses processos decisórios, posto que modificam incentivos para tomar decisões relacionadas a endividamento. As organizações que se beneficiam do fato de possuírem partes relacionadas domiciliadas em outros países poderão agir de forma distinta de seu próprio histórico de financiamento, produzindo evidência da intensidade da relação entre variação nos tributos e variação na estrutura de capital. A contribuição empírica deste estudo consiste da identificação desta evidência, que se constitui, essencialmente, da diferença na sensibilidade da estrutura de capital a regras tributárias, considerando empresas sujeitas a essas regras em relação àquelas que não são sujeitas. Buscouse descrever essas mudanças na estrutura de financiamento de empresas que possuem condições para o emprego de endividamento excessivo e que, em face de alterações nessas condições, passaram a tomar decisões distintas daquelas que vinham sendo tomadas antes da intervenção.

As vantagens decorrentes de empréstimos intercompanhia incluem, mas não se restringem a, economia tributária (Clausing, 2009; Egger, Eggert, Keuschnigg, \& Winner, 2010), redução do risco de falência de empresas do grupo (Gopalan, Nanda, \& Seru, 2007), viabilização de investimentos quando as condições do mercado são adversas ou o ambiente legal é arriscado (Desai, Foley, \& Hines Jr., 2004) e aproveitamento das diferenças entre taxas de juros dentre os países hospedeiros (Egger, Keuschnigg, Merlo, \& Wamser, 2014). Embora o espectro de possibilidades resultantes do uso desta forma de financiamento seja diverso, as investigações mais recentes sobre os determinantes da dívida intercompanhia tem o aspecto tributário como principal foco (Büettner, Overesch, Schreiber, \& Wamser, 2012; Büettner \& Wamser, 2013; Mintz \& Smart, 2004). Estudos sobre regras de subcapitalização têm sido realizados em diversos países e contextos tributários (Büettner \& Wamser, 2013; Cheung, 2012; Elliffe, 2013; Göritzer, 2012; Hauptman \& Tič, 2014; OECD, 2012; Wamser, 2014). Tem sido investigado, por exemplo, o uso de empréstimos intercompanhia para fins de planejamento tributário e a efetividade das contramedidas em relação à subcapitalização (Overesch \& Wamser, 2010a), o uso de empréstimos intercompanhia para realizar profit shifting ${ }^{2}$ (Büettner \& Wamser, 2013), a relação entre regras de subcapitalização e decisões de financiamento e investimento (Schreiber, Overesch, Büettner, \& Wamser, 2006) e o efeito de regras de

\footnotetext{
2 Prática que transfere lucros de um local de alta tributação para outro de menor tributação no intuito de economizar no pagamento de impostos sobre a renda.
} 
subcapitalização na estrutura de capital das empresas (Hauptman \& Tiě, 2014; Massbaum \& Sureth, 2009; Wamser, 2014). Pesquisas dessa natureza no ambiente regulatório brasileiro são inexistentes e poucos estudos sobre determinantes de estrutura de capital não consideram o aspecto tributário nesta relação, salvo poucas exceções (Pohlmann \& Iudícibus, 2010). Na investigação presente, foram empregados dados oriundos de informações contábeis, obtidas nas demonstrações financeiras divulgadas em jornais de grande circulação e produzidas pelas empresas pertencentes aos dois grupos comparados. Os estudos mais recentes a investigar efeitos de normas de subcapitalização empregam dados obtidos em bancos centrais, no caso de estudos alemães, ou obtidos em mercados financeiros, no caso de estudos americanos, por exemplo.

Esta investigação empírica se deu por meio do estimador de diferenças em diferenças. Para fins da análise econométrica, o grupo tratamento foi definido como o grupo das empresas que possuem atividade societária no Brasil e partes vinculadas estrangeiras, conforme definições legais. A unidade de análise consiste dos dados dessas unidades de negócios situadas no Brasil, obtidos por meio das demonstrações financeiras publicadas em jornais de grande circulação. O grupo controle consiste de empresas brasileiras que não possuem partes relacionadas domiciliadas ou residentes no exterior. $\mathrm{O}$ estimador de diferenças em diferenças compara as observações de dois grupos em dois momentos distintos: antes e após a intervenção. Neste caso, a intervenção consiste da vigência da lei que estabelece as regras para dedução de juros oriundos de empréstimos intercompanhia. Em face do processo legislativo brasileiro e das determinações para produção de efeitos de leis, foi considerado o ano de 2011 como início do período sujeito à existência de efeitos.

Uma condição para que se descreva de forma adequada uma relação causal é o fato de que o tratamento seja administrado às unidades experimentais, inclusive ao grupo controle, aleatoriamente, entendendo-se por "unidade experimental" o nível informacional de coleta de dados, como indivíduo, empresa ou estado, por exemplo. Portanto, a probabilidade de ocorrência de intervenção, e mesmo de não intervenção, deve ser a mesma para todos os sujeitos envolvidos no estudo. Isso implica no fato de que os dois grupos, tratamento e controle, devem ser tão semelhantes quanto possível no que tange às suas características observáveis e nãoobserváveis, não existindo correlação entre o fato de determinada unidade experimental receber o tratamento e alguma característica previamente existente dessa unidade. Dessa forma, quaisquer diferenças observadas entre os dois grupos ao final do estudo dificilmente serão 
resultantes de diferenças previamente existentes entre eles (Shadish, W.R., Cook, T.D., \& Campbell, 2002), tornando possível atribuir o efeito observado à intervenção.

Esta característica dos chamados experimentos verdadeiros ou experimentos do padrão ouro é denominada, em inglês, random assignment e está ligada ao fato de ser possível manipular as condições em que ocorre a intervenção cujos efeitos são investigados. No entanto, em algumas situações, isso não é possível. Ainda, conforme Shadish, Cook e Campbell (2002), quando o tratamento é atribuído às unidades experimentais de forma não aleatória, mas a intervenção ainda é manipulável, tem-se a condição definida como quasi-experimento, enquanto que, não havendo possibilidade de se manipular a intervenção, como em desastres naturais, tem-se um exemplo de experimentos naturais. Estudos de natureza quasiexperimentais envolvem tratamentos aplicados a voluntários, a exemplo de participantes de testes em medicamentos ou voluntários do serviço militar, ou, como no caso deste estudo, a grupos escolhidos previamente, como o desenvolvimento de políticas governamentais cujos focos são grupos específicos de empresas. Nesta situação, os grupos diferem entre si e torna-se necessário identificar e controlar possíveis e plausíveis causas alternativas para o efeito observado. Em geral, tal se dá por meio de comparações entre os grupos antes da intervenção. Este método torna-se complexo e caro, podendo criar fragilidades internas ao estudo ou mesmo inviabilizá-lo operacionalmente.

O emprego do estimador de diferenças em diferenças demanda, dos dados, o atendimento a determinadas condições para que possa apresentar resultados adequados à descrição da relação causal. Tais condições são explicadas na seção Estratégia de Identificação deste texto. Atendidos os requisitos do método, a análise se dá de forma direta, com baixos riscos de que causas que não sejam a intervenção produzam efeitos que possam ser confundidos com os que se deseja medir. Portanto, este estudo pode ser classificado como um quasi-experimento em que determinado grupo de organizações foi escolhido, por legisladores, para sujeitar-se aos efeitos de determinada lei. As condições para que a lei produza efeitos na estrutura de capital destas organizações depende de elementos que, espera-se, são semelhantes aos existentes no grupo de empresas que não possuem partes relacionadas residentes ou domiciliadas no exterior. Consequentemente, a acurácia da descrição da relação causal que se propoe depende de comprovar a comparabilidade entre os grupos e de controlar as causas alternativas para o efeito observado. Embora seja possível verificar a comparabilidade entre os grupos antes da intervenção, empregou-se, em análise complementar, a metodologia do Propensity Score Matching (PSM) no intuito de identificar indivíduos semelhantes entre si, mas pertencentes a 
grupos diferentes. Em síntese, a diferença observada na mudança da variável de interesse entre estes indivíduos denota o efeito do tratamento.

Os termos da lei definem a existência de partes relacionadas estrangeiras como condição necessária para que a lei exerça efeitos. Também estabelecem que o efeito da lei depende da composição do endividamento total das empresas. No entanto, apesar das possíveis diferenças existentes quanto ao grau de endividamento intercompanhia das entidades avalidas, este estudo partiu da premissa de que as empresas constantes na amostra analisada, possuindo partes vinculadas estrangeiras ou não, estão sujeitas às mesmas condições institucionais existentes no país, diferindo apenas quanto à existência de associados no exterior. Potém, esta condição pode guardar correlação com atributos das empresas, fato com que se buscou lidar por meio da escolha do método empírico empregado. O emprego do PSM contribui para a identificação do efeito da lei ao possibilitar a comparação do efeito observado entre unidades dos dois grupos. O objetivo do método é que, embora pertençam a grupos diferentes, as empresas pareadas possuem similaridades, no que tange a características observáveis. Portanto, ao comparar unidades tão semelhantes quanto possível, pretendeu-se acrescentar robustez aos resultados verificados por meio de regressão. Apresentam-se, na seção apropriada, tanto os dados com o uso do PSM quanto sem o uso deste método.

De fato, qualquer lei brasileira é vigente para toda pessoa física ou jurídica que habite o país. Porém, a observação de efeitos da lei que interessa a este estudo é possível apenas naquelas entidades que excedem os valores especificados pela lei e que, portanto, a fim de seguirem suas estratégias organizacionais ou mesmo para não perderem valor, deverão modificar suas políticas. Empresas cujos EICs encontram-se acima dos limites poderão, por exemplo, reduzir esses valores para evitar o aumento do pagamento de tributos sobre a renda. Caso contrário, sofrerão com a redução da rentabilidade de sua operação, dado que a carga tributária final será maior, mantidas constantes as outras condições. Poderão também substituir os EICs por empréstimos bancários, mantendo o endividamento total e a carga tributária final, com efeitos sobre a eficácia esperada da lei. Subsidiárias cujos EICs encontram-se abaixo dos limites poderão decidir por se ajustar até o limite permitido ou não fazer nada. Este comportamento dificilmente teria suas razões observadas em demonstrações financeiras e, além disso, não é objeto deste estudo. As empresas domésticas, por sua vez, poderão decidir mudar suas estruturas de financiamento aleatoriamente, em função de variáveis observáveis ou nãoobserváveis que, em tese, também afetam o grupo de multinacionais na mesma intensidade. 
Embora os grupos possam apresentar reações médias distintas frente à intervenção, bem como ser diferentes em termos de atributos observáveis, a premissa do estimador empregado é a de que a tendência da variável de interesse, em relação a características observáveis e ao tempo, seja a mesma para os dois grupos antes da intervenção. Observada essa premissa, grupos diferentes podem, teoricamente, ser comparados como se a intervenção fosse um evento aleatório típico de experimentos do tipo ideal e, sob tais condições, as diferenças observadas entre os dois grupos podem ter interpretação causal.

Os resultados obtidos neste estudo indicam a inexistência de efeitos significantes da lei em questão sobre a estrutura de financiamento dos recursos empregados na atividade das organizações que compõem a amostra analisada. O efeito estimado se mostrou negativo e não diferente de zero, mesmo na presença de controles adicionais observáveis em nível individual ou ao permitir que os grupos tenham tendências seculares distintas no que tange à evolução da variável dependente, embora a tendência seja de aumento do endividamento em ambos os grupos. Ainda, se considerados em relação ao Patrimônio Líquido, estas tendências mantêm trajetória de elevação, embora menos acentuada no grupo de empresas que possuem partes vinculadas estrangeiras.

Este trabalho está dividido como se segue. A Seção I apresenta uma síntese do contexto, teoria, método e resultados mais detalhes, bem como os fundamentos teóricos da investigação. A Seção II fornece informações acerca da legislação tributária brasileira no que tange a tributos federais sobre a renda de empresas e como essa tributação se relaciona com e interfere nas normas contábeis aplicadas no Brasil, bem como descreve como se deu a criação de normas de subcapitalização no Brasil, suas semelhanças ou diferenças com outras normas em outros países e quais são as principais implicações para as empresas em um contexto mundial. A Seção III descreve os dados e sua metodologia de coleta, explica o uso dos métodos empregados e analisa a estratégia de identificação dos efeitos da lei. A Seção IV introduz os dados por meio de estatísticas descritivas, a Seção V analisa os resultados. A Seção VI apresenta as considerações finais ao trabalho, suas implicações teóricas, fragilidades, delimitações e apontamento de novos desafios empíricos e, na Seção VII, podem ser encontradas as referências consultadas. 


\section{Fundamentos Teóricos}

\section{Estrutura de capital}

Provavelmente, o trabalho mais influente no campo de estudos sobre estrutura de capital é o de Franco Modigliani e Merton Miller (MM), publicado em 1958. Em seu estudo, o principal objetivo era desenvolver uma teoria adequada para explicar a influência da estrutura de financiamento das firmas sobre seu custo de capital e, consequentemente, seus valores de mercado. MM iniciam seus questionamentos ao observar que, além de que os retornos dos ativos de uma firma sejam incertos, o capital usado para adquirir tais ativos pode vir de fontes diversas que agregam medidas variadas de incerteza, como títulos de dívidas que geram obrigações previamente estabelecidas ou capital próprio, que conferem a seus proprietários direitos a uma parcela dos resultados apresentados pela firma, quando existentes. Ao apresentarem, as fontes de recursos, risco, a usual avaliação de investimentos com base em previsibilidade de fluxos de caixa, tão comum nos trabalhos da época, pode não representar a realidade, sendo necessário incluir medidas de risco.

Por outro lado, MM defendem que, embora alguns avanços tenham sido feitos para permitir a existência da incerteza ao adotar o conceito de "prêmio por risco" ou "desconto por risco", não se pode evitar a crítica pragmática que surge neste contexto. Segundo os autores, ao serem extrapoladas as decisões de investimento para um contexto onde há incerteza, a equivalência entre os critérios de decisão "maximização de lucro" e "maximização de valor de mercado" deixaria de existir. A inclusão da incerteza quanto aos fluxos de caixa de ativos faz com que as variáveis de interesse, lucro e valor de mercado, não possam mais ser vistas como determinísticas, mas passem a ser observadas como variáveis aleatórias e, portanto, sujeitas apresentar variações tanto em sua dispersão quanto em seu valor esperado em decorrência, inclusive, das decisões de financiamento (Modigliani \& Miller, 1958).

Neste contexto de inserção da incerteza na análise de investimentos alternativos, em que valores esperados e suas respectivas dispersões criam uma miríade de opções possíveis, funções individuais subjetivas de utilidade passam a ter relevância no processo decisório de investimentos dos recursos de credores e acionistas. No entanto, MM argumentam que não se poderia garantir que as decisões de investimento em uma dada firma seguem as funções de utilidade de todos os investidores. A abordagem sob a perspectiva do valor de mercado, segundo MM, vem a sanar essa discrepância, dirigindo as decisões de investimento àquelas que elevariam o valor das ações de uma empresa, ou seja, atendendo, em tese, as preferências de 
todos as classes de investidores. No entanto, MM atestam que, à época de seu estudo, os resultados da aplicação dessa abordagem pouco haviam contribuído para o esclarecimento da relação entre investimentos, financiamento e valor de mercado. Segundo os autores, a causa da pequena importância das pesquisas se constituía da inexistência de uma teoria que explicasse, efetivamente, o efeito da estrutura financeira sobre o valor de mercado das firmas, bem como apresentasse formas para interpretar estes efeitos e suas causas a partir de dados empíricos do mercado.

Além de suas já amplamente referenciadas Proposições I e II, que atestam que o valor da firma é independente de sua estrutura de capital e que o retorno esperado da ação ordinária de empresas alavancadas deve ser ajustado por um "prêmio por risco financeiro", outra tese que MM defendem é o fato de que, em um ambiente onde o pagamento de juros é dedutível no processo de apuração de tributos sobre o lucro, o valor da firma, em equilíbrio, deve ser proporcional ao retorno esperado deduzido desses tributos, ao invés de ser proporcional aos benefícios esperados advindos de seus ativos fixos. Sendo dedutíveis os juros para fins de cálculo de tributos sobre a renda, o aumento da proporção de dívida na estrutura de capital, por sua vez, resulta em ganhos para os acionistas ordinários, mantidas outras condições constantes. É importante observar que essa constatação não necessariamente implica, segundo $\mathrm{MM}$, em aceitar a existência de uma estrutura de capital ótima para cada firma individualmente.

Exagerar a relevância teórica das considerações de MM constitui tarefa difícil. As possibilidades de pesquisa originadas deste estudo ainda não foram totalmente exploradas, constituindo, as dificuldades empíricas, uma das razões. Não obstante, os autores acrescentaram correções em suas constatações feitas em 1958. Em seu trabalho de 1963, Modigliani e Miller (MM') preveem, por meio de aprimoramento de suas conclusões realizadas no trabalho de 1958, que a diferença entre a estrutura de capital de duas firmas determina, em sinergia com a alíquota de tributos sobre o lucro, o valor de mercado das mesmas. Os autores afirmam que diferentes estruturas de capital, quando comparadas firmas em uma mesma classe de risco, eliminam a proporcionalidade esperada entre o valor de mercado da firma e o lucro após a dedução de tributos, ou seja, o mercado pagará uma quantidade diferente de valor para cada unidade monetária de lucro de empresas com diferentes estruturas de capital, mesmo que elas estejam sujeitas às mesmas condições de risco no que tange à realização de seus lucros operacionais esperados.

De fato, a diferença entre os dois estudos reside principalmente na constatação, no estudo de 1963, de que o benefício tributário da dívida, além de real, não contém risco, dado o retorno 
ordinário antes dos tributos, enquanto que o próprio retorno antes dos tributos é incerto. Nas palavras dos autores, traduzidas livremente:

\begin{abstract}
"Em nossa formulação original, os valores (das firmas) dentro de uma classe (de risco) são exclusivamente proporcionais aos retornos esperados após os tributos (sobre o lucro). Dessa forma, o benefício tributário da dívida se daria somente como função do fato de que a dedutibilidade do pagamento de juros implica em um valor maior de lucros após os tributos para qualquer dado valor de lucro antes dos tributos. Após correções, no entanto, existe um ganho adicional devido ao fato de que o ganho extra após os tributos (benefício tributário da dívida dado pelo produto entre o pagamento dos juros e a alíquota de tributos) representa um ganho certo, enquanto que o (valor esperado do) retorno antes dos tributos contém risco. Portanto, este ganho deve ser capitalizado a uma taxa mais favorável (a taxa média da dívida), ao invés de ser capitalizado pela taxa maior (exigida por acionistas) aplicada a fluxos incertos" (Modigliani \& Miller, 1963, p. 438, texto entre parênteses adicionado).
\end{abstract}

MM assertam que, após considerado o efeito da emissão de dívida sobre os preços das ações ordinárias de uma firma, a diferença entre o custo de dívida e o custo de emitir novas ações advém exclusivamente do efeito tributário da dívida. Assim sendo, segundo os autores, quanto menor a taxa de juros comprometida em emissão de dívida, menor será o benefício desta emissão para os acionistas e, portanto, menor será o incentivo a tal política, argumento que defende a relevância da taxa de juros praticada no mercado no processo decisório de financiamento das operações.

Sendo as altas taxas de juros condição necessária para a existência de benefícios tributários cada vez maiores, por que então as empresas não se endividam até o máximo de suas necessidades de recursos financeiros? Este e outros dos principais aspectos teóricos pesquisados na relação entre dívida e tributos e estrutura de capital encontram-se elencados em outro trabalho seminal de Miller (1977), e, especificamente, a relação entre altas taxas de juros e benefícios tributários constitui uma das principais motivações para a existência deste texto, mesmo décadas após se iniciarem os questionamentos sobre a matéria. O antagonismo entre benefícios tributários de dívidas e custos de falência, especialmente para empresas pouco alavancadas, o descolamento entre a elevação de tributos sobre a renda nos Estados Unidos da América no início do século passado e os índices médios de estrutura de capital ou, ainda, a variação cross sectional desses índices são alguns dos aspectos apontados por Miller (Op. cit.) em suas propostas acerca dos aspectos teóricos das estruturas de capital. Alguns dos quais têm sido extensivamente testados (DeAngelo \& Masulis, 1980; Flath \& Knoeber, 1980; Schneller, 1980; Taggart, 1980).

De acordo com Miller (1977), se, por um lado, dívida provê a vantagem da dedutibilidade do pagamento de juros, por outro, o custo da dívida contratada já inclui os efeitos dos diferenciais de tributos sobre a renda que investidores pagam ao emprestar para as firmas ao 
invés de adquirir títulos patrimoniais. Esta relação é determinada pelo equilíbrio existente entre a alíquota padrão de tributos sobre o lucro empresarial e as alíquotas individuais de tributos incidentes sobre os lucros auferidos com títulos de dívida e sobre os ganhos advindos de ações. Alterações nessas taxas causariam oportunidades para "arbitragem" que rapidamente seriam absorvidas pelo mercado em um contexto de progressividade de tributos ao nível individual, eliminando o incentivo para emitir mais dívida ou ações e restaurando novamente um equilíbrio em que não haveria diferença, para o emissor dos títulos de dívida ou ações, entre a emissão de um ou de outro. Portanto, neste contexto em que o mercado para títulos de dívida e ações precifica tributos a nível do investidor, exigindo do credor tributos que o incentivam a demandar maiores taxas da empresa emissora, o valor da empresa, em equilíbrio, seria independente da estrutura de capital adotada, mesmo considerando a dedutibilidade, para fins tributários, do pagamento de juros sobre os empréstimos (Miller, 1977, p. 269).

No que tange à influência que o mercado de títulos de dívida possui sobre esta relação, a taxa de juros de equilíbrio entre a oferta e a demanda por tais títulos seria dada, conforme Miller (1977), pelo produto da taxa de juros isenta de tributação e um coeficiente gerado (grossed up $)^{3}$ a partir da alíquota legal de tributos sobre a renda das empresas. Com a taxa de juros de mercado abaixo deste produto, investidores que se enquadram nas categorias mais baixas de tributação criarão demanda por títulos, enquanto que não haverá interesse por parte dos investidores sujeitos a tributação mais elevada, dado que a taxa de juros oferecida nestes casos não lhes é suficiente para compensar o custo tributário. Neste caso, se houver pressão por parte do lado da oferta de títulos, a taxa de juros deverá subir para compensar a tributação "pessoal" do investidor marginal, atraindo-o para o mercado. Investidores cujas alíquotas de tributos sobre a renda de juros encontram-se nos níveis superiores apenas adquirirão títulos de dívida cujas taxas de juros possibilitem uma obtenção de retorno após tributos ao menos equivalente ao que seria obtido com o investimento em ações da mesma companhia, ou seja, estes investidores buscarão ter tributação sobre suas rendas equivalente àquela dos stockholders, descontados os tributos sobre receitas de juros.

As constatações teóricas de Miller (1977) conduzem à seguinte relação de equilíbrio deste mercado de títulos (p. 267):

${ }^{3}$ Taxa de juros de equilíbrio $=\frac{r_{0}}{1-\tau_{C}}$, em que $r_{0}$ é a taxa de juros de títulos isentos de tributação. 


$$
G_{L}=\left[1-\frac{\left(1-\tau_{C}\right) *\left(1-\tau_{P S}\right)}{\left(1-\tau_{B}\right)}\right] * B_{L}
$$

Nesta relação, $G_{L}$ representa o Ganho advindo da alavancagem, $B_{L}$ consiste do valor de mercado da dívida, $\tau_{\mathrm{C}}$ é a alíquota de tributos sobre a renda das firmas, $\tau_{\mathrm{PS}}$ é a alíquota pessoal de tributos sobre ganhos com ações ordinárias e $\tau_{\mathrm{B}}$ é a alíquota pessoal de tributos sobre ganhos com receitas de juros. À página 267, Miller asserta que:

\begin{abstract}
“... quando todos os tributos são iguais a zero, a expressão se reduz ao já conhecido ganho zero de alavancagem, visto em MM. Quando a alíquota pessoal de tributos sobre ganhos com juros é igual àquela que incide sobre os ganhos com ações ordinárias (...), o ganho com alavancagem é o tradicional $\tau_{\mathrm{C}}{ }^{*} \mathrm{~B}_{\mathrm{L}}$. No entanto, quando a alíquota pessoal que incide sobre ganhos com ações for menor do que aquela que incide sobre ganhos com juros, o ganho com alavancagem se torna inferior a $\tau_{\mathrm{C}}{ }^{*} \mathrm{~B}_{\mathrm{L}}$. De fato, para uma ampla gama de valores de $\tau_{C}, \tau_{\text {PS }}$ e $\tau_{B}$, o ganho com alavancagem desaparece completamente ou pode até mesmo se tornar negativo!" (Miller, 1977, p. 267, tradução livre).
\end{abstract}

Portanto, sendo a alíquota pessoal incidente sobre ganhos com ações ordinárias inferior àquela que incide sobre receitas de juros, Miller (1977) advoga em favor de que, nesta condição, os ganhos auferidos pelas empresas com alavancagem podem não ser tão significativos a ponto de interferir na relação entre valor da empresa e sua estrutura de capital, posto que o multiplicador gerado pela relação entre estas duas taxas no modelo teórico será menor do que 1 (um). No entanto, embora argumente que mesmo em cenários "reais" a alíquota pessoal marginal de tributos sobre rendimentos de ações ordinárias possa ser próxima de zero, o autor relega a discussão microeconômica da existência ou não de uma estrutura de capital "ótima" a estudos posteriores (p. 269, nota de rodapé número 20). Ainda, o modelo de equilíbrio de Miller (1977) assume que todas as firmas estão sujeitas a uma mesma alíquota marginal de tributos, o que pode ser prontamente rejeitado (Myers, 1984).

Pesquisas subsequentes demonstraram que o modelo de Miller (1977) é sensível a modificações simples e realistas nas leis tributárias. Por exemplo, o fato de que a existência de benefícios tributários não relacionados a dívida, tais como depreciação ou créditos por investimentos, pode tornar inválidas algumas constatações do modelo, permitindo tanto a existência de uma estrutura ótima de capital para cada firma individualmente quanto a inclusão de custos de falência na precificação dos benefícios tributários (DeAngelo \& Masulis, 1980). Além da existência de uma estrutura ótima de capital a ser buscada pelas firmas, defende-se que este grau de endividamento deverá estar negativamente correlacionado aos benefícios tributários ditos "substitutos" daqueles oriundos de dívida, conforme modelo de DeAngelo e Masulis (1980) que, conforme sugestão de pesquisa constante em Miller (1977), testaram 
hipóteses em dados cross sectional e de time series da estrutura de capital, cujas variações já eram questionadas em MM.

Desde 1977, parte dos papers produzidos lida com testes empíricos que buscam corroborar ou contradizer as proposições de MM, MM' e Miller (1977). Ao se analisar o modelo de equilíbrio proposto por Miller (1977) em condições de mercados imperfeitos, constata-se que o equilíbrio descrito pode receber interferência de fatores como diferenciais de custo, entre as empresas, para emissão de dívidas. De acordo com Taggart (1980), firmas com menores custos emitirão mais dívida e, nestas condições, a demanda dos investidores por títulos de dívida encontrará resistência no aumento da taxa de tributos sobre receita de juros em relação aos títulos cujos rendimentos são isentos de tributação, corroborando a ideia da influência dos tributos pessoais sobre o processo de contratação de dívida. Flath e Knoeber (1980) constatam que tributos e custos de falência implicam na existência de uma estrutura ótima de capital, embora, em estudo posterior, Myers (1984, p. 588) relate desconhecer qualquer investigação que tenha apontado claramente efeitos significantes de tributos sobre a política de financiamento das empresas.

Por outro lado, a dicotomia entre propriedade e controle contribui para a existência de uma das mais influentes teorias sobre a determinação da estrutura de capital: sua função em mitigar problemas relacionados aos interesses dos administradores das empresas (Aghion \& Bolton, 1989). Previamente, Jensen e Meckling (1976) defendem que as razões e processos que resultam na existência dos custos de agência delineiam uma teoria da estrutura de capital ou de propriedade das empresas. Segundos os autores, custos de agência resultam da divergência de interesses entre principal e agente e podem tomar as formas de custos de controle, de custos de ajustamento ou de custos residuais. Em seu trabalho, Jensen e Meckling usam o termo contrato, implícito ou explícito, para descrever a instância em que se definem os direitos de propriedade das partes e introduzem formas por meio de que atividades de monitoramento e controle são empregadas para reduzir custos de agência. Dentre estas atividades, a contratação de dívida, e simultâneo comprometimento de fluxos de caixa livres, reduzem custos de agência ao restringirem a quantidade de recursos disponíveis à administração, limitando o escopo de possíveis ações gerenciais contrárias ao entendimento dos acionistas. Neste sentido, a contratação de dívida, especialmente dívida emitida em troca de ações em circulação, entregam, aos acionistas, o direito de levar a companhia ao tribunal de falências, caso não recebam os pagamentos de juros e principal, que seriam, antes da contratação da dívida, dividendos (Jensen, 1986). 
Posteriormente, verificou-se que um efeito substancial sobre a sensibilidade da estrutura de capital das firmas a tributos pode ser exercido por regras de subcapitalização (Büettner et al., 2012). Uma das possíveis justificativas para tal, conforme Büettner e Wamser (2013), é o fato de que empréstimos intercompanhia são usados para transferência de lucros a outros países por meio de endividamento intercompanhia e o principal determinante dessas operações é o diferencial das alíquotas de tributos entre os países onde o grupo empresarial atua. Enquanto a combinação entre alta alíquota de tributos sobre o lucro e elevados custos de obtenção de empréstimos externos em países hospedeiros é tida como um dos principais determinantes do uso de empréstimos internos, Egger, Keuschnigg, Merlo, \& Wamser (2014) descrevem em maiores detalhes como outras variáveis, além do diferencial de alíquota, influenciam essas operações, em sinergia com o aspecto tributário.

Adicionalmente, Wamser (2014) encontrou que normas de subcapitalização restringem o uso de dívida interna, fazendo com que as firmas substituam este tipo de dívida por dívida externa. Neste sentido, Hammer e Kvarberg (2015) apresentam evidências de redução do endividamento interno de empresas norueguesas pertencentes ao quintil de maior endividamento de sua amostra, enquanto que a substituição do endividamento interno por externo possa também ter ocorrido nesta sub-amostra, dado que os autores não encontraram evidência significante de elevação do endividamento total. No entanto, a pesquisa sobre a substituibilidade entre os dois tipos de capital, embora possa ser uma contribuição empírica significativa ao entendimento das relações entre tributos e estrutura de capital, não tem tido continuidade. Similarmente, as ideias tradicionais acerca da relação entre dívida e estrutura de capital, bem como tributos, ainda carecem de ter, adicionadas a seus âmbitos, o aspecto intercompanhia de algumas dessas operações.

É possível que a cessão de recursos onerosos para partes vinculadas estrangeiras consista de apenas investimento ordinário de capital, avaliado com uma análise do tradeoff entre incremento de fluxo de caixa e variações de tributos sobre a renda. Por outro lado, a companhia que toma recursos se depara, além dessa, com as alternativas regulares de obtenção de crédito descritos nas teorias correlatas: dívida externa, recursos próprios e emissão de ações, quando este caso se aplica. $\mathrm{O}$ endividamento intercompanhia cria espaço para a abordagem destes recursos em comparação com as alternativas anteriores. Teoricamente, o uso de dívida interna poderia permitir o endividamento total, mas também pode resultar tanto de dificuldades de obtenção de crédito em diferentes países quanto da prática de atos de planejamento tributário. 


\section{Subcapitalização (thin capitalization) e a mobilidade de recursos financeiros}

Estudos empíricos têm contribuído para: (i) esclarecer a importância da dívida interna para decisões de planejamento tributário (Chowdhry \& Coval, 1998; Schindler \& Schjelderup, 2012), (ii) descrever as condições externas a que subsidiárias estão expostas e, por isso, buscam endividamento interno (Desai et al., 2004; Gopalan et al., 2007) e (iii) explicar a influência do endividamento interno na formação da estrutura de capital (Büettner et al., 2012; Buettner, Overesch, \& Wamser, 2015). Outras evidências empíricas apontam para a importância de operações como alocação de dívida entre subsidiárias e transferência de lucros determinada pela intensidade dos investimentos em pesquisa e desenvolvimento. Tais investimentos podem influenciar a diferença entre as lucratividades de companhias domiciliadas em países com altas ou baixas alíquotas de tributos sobre a renda (Grubert, 2003). No entanto, a investigação acerca do uso dos empréstimos intercompanhia para fins de transferência de lucros ainda segue sem conclusões empíricas definitivas (Büettner \& Wamser, 2013).

Se, sem uma restrição ao uso de recursos intercompanhia, obter financiamento desse tipo coloca as empresas em situação melhor do que estariam se obtivessem financiamento externo, então é possível que decisões de financiamento das atividades empresariais sejam afetadas por regras que restrinjam essa fonte de recursos. Além do benefício tributário da dívida, custos como os de agência e de falência podem se comportar de maneira distinta quando relacionados a EIC, dada a possível assimetria informacional envolvida, se comparados àqueles oriundos de empréstimos externos. Na presença de restrições que modificam o valor do benefício auferido ao se obter financiamento de uma fonte específica, é possível, portanto, que a administração das companhias pondere se é viável manter os empréstimos intercompanhia ou se estes devem ser substituídos por recursos advindos de outras fontes. No entanto, pouco se sabe sobre a possibilidade e condições nas quais essa substituição ocorre (Hammer \& Kvarberg, 2015; Schreiber et al., 2006).

Empréstimos oriundos de partes relacionadas apresentam, na prática, as mesmas características de um empréstimo oriundo de entidades especializadas em financiar empresas: envolvem contratos, partes, taxas, prazos e recursos financeiro. No entanto, alguns aspectos relacionados à aplicação e monitoramento do uso dos recursos emprestados diferem entre as duas modalidades. Gertner, Scharfstein, e Stein (1994) defendem que a alocação de recursos intercompanhia leva a um maior monitoramento do que a obtenção de dívida externa, além de reduzir a propensão dos gestores ao empreendedorismo e facilitar a realocação de ativos quando 
o desempenho econômico destes o justificar. Segundo os autores, a principal diferença consiste no fato de que, no caso dos empréstimos intercompanhia, a parte cedente dos recursos é, ao menos parcialmente, proprietária da unidade de negócios para quem cede os recursos, permitindo o acompanhamento de seu uso. A priori, se poderia lidar com a questão desse monitoramento por meio da centralização da origem dos financiamentos em uma única fonte, mesmo no caso de recursos externos. No entanto, a visão de Gertner, Scharfstein, e Stein (1994) é a de que o empréstimo externo coloca os direitos de controle sobre o uso dos ativos da empresa sob a égide da administração, enquanto o empréstimo interno mantém este controle sob a tutela do fornecedor do recurso, ou seja, o próprio grupo econômico.

Ainda, o acesso limitado à informação, em que pesem os conceitos de risco moral e assimetria de informação, desempenha papel relevante na distinção entre os ambientes transacionais que envolvem recursos internos e externos. Partes relacionadas cessoras de recursos podem contar com informações indisponíveis a, por exemplo, bancos e, por isso, podem selecionar, dentre as unidades de negócios a que estão vinculadas, aquelas que apresentam melhor expectativa de rentabilidade (Stein, 1997). Esta é uma das razões pelas quais o mercado interno de capitais pode apresentar eficiência distinta da que apresenta o mercado externo. De fato, existe divergência entre posicionamentos teóricos e evidências empíricas em favor da maior ou menor eficiência dos mercados internos de capital em relação aos mercados externos. Se, por um lado, mercados internos de capitais podem funcionar mais eficientemente que os externos, alocando recursos de forma mais adequada, por outro, nestes mercados há também evidência de assimetrias informacionais, distorcendo decisões de alocação (Zhang, Hom, \& Kong, 2014).

As condições relacionadas à existência dos EIC no Balanço Patrimonial das companhias têm sido investigadas com maior frequência do que têm sido seus efeitos sobre a economia do país em que se instalam. Trabalhos seminais como Desai, Foley e Hines Jr. (2004) estudam a relação entre condições institucionais no país hospedeiro, como taxas de juros, desenvolvimento do mercado de capitais e direitos de credores, e o uso de EIC por subsidiárias americanas. Estes autores encontram que a elevação das taxas de juros para empréstimos externos causa a redução do uso destes recursos, com subsequente elevação, embora em proporção menor em relação ao Ativo Total, dos EIC. Além do custo financeiro, um dos principais aspectos citados na literatura correlata é a alíquota dos tributos dos países em que a multinacional atua, em especial, o diferencial de alíquotas observado entre esses países. Egger, Eggert, Keuschnigg e Winner (2010) apresentam evidências de que empresas pertencentes a 
companhias estrangeiras geram índices de alavancagem significantes e superiores aos de suas contrapartes localizadas em seus países de origem e que essa diferença aumenta com a elevação da alíquota de tributos sobre o lucro no país hospedeiro. Overesch e Wamser (2010b) também apresentam evidência empírica da influência dos diferenciais de alíquotas entre os países em que o grupo empresarial atua na determinação do endividamento interno de subsidiárias alemãs.

O aspecto tributário do endividamento intercompanhia tem sido investigado empiricamente por meio da análise do efeito de intervenções exógenas na figura de leis que afetam benefícios tributários já desde a década de 1990 (Gordon \& MacKie-Mason, 1990). Se, por um lado, o aspecto do diferencial de alíquota é atraente para ter a si atribuída a principal responsabilidade na determinação da dívida intercompanhia (Blouin \& Huizinga, 2014; Desai et al., 2004; Overesch, 2009), outros estudos apontam que, além de explorar a oportunidade do planejamento tributário, a superação de problemas institucionais específicos do país hospedeiro e de dificuldades na obtenção de financiamentos externos são talvez mais importantes do que a primeira justificativa (Egger et al., 2014).

Em se tratando de grupos empresariais com atuação nacional, Stein (1997) descreve o critério para distribuição de recursos financeiros como uma prática discricionária de "escolha do vencedor", ou seja, por meio do exercício dos direitos de controle sobre o capital, a matriz do grupo empresarial direciona recursos à divisão que apresenta melhor desempenho. Segundo o autor, fornecedores externos de capital, como os bancos, não possuem esta prerrogativa, o que consiste em um dos elementos que distinguem as fontes de recursos internas das externas e tendo influências na relação de agência criada pela dívida. Não há razões para se crer que tal não ocorra também no caso de grupos multinacionais, embora outras variáveis possam ter maior ou menor peso nas decisões nesses casos. Um exemplo empírico desta constatação pode ser encontrado em Lamont (1997). Neste estudo, é descrita a redução de investimentos ocorrida em 1986, ano de crise nos preços do petróleo. O autor encontrou, ao analisar dados de empresas que tinham operações relacionadas a petróleo e em outras indústrias, evidências desta redução em unidades de negócios não relacionados ao petróleo como decorrência da queda dos resultados nos negócios naquele setor em crise. Constatações desta natureza corroboram o arcabouço (framework) proposto por (Gertner et al., 1994), em que os autores propõem que a alocação interna de capital facilita a redistribuição de recursos, embora os incentivos à postura empreendedora dos gestores seja penalizada, dado que a disponibilidade de recursos para investimentos depende ainda mais da discricionariedade da entidade controladora. 
A pesquisa sobre as condições e interesses que determinam a mobilidade de capitais dentro de um grupo empresarial, como exposta nos parágrafos anteriores, apresenta enfoque nos benefícios econômicos que este fenômeno proporciona ao grupo. Egger et al. (2014) propõem um modelo teórico para empresas multinacionais que operam com mercados internos de capitais. Os autores partem das premissas de que a produtividade individual e tributos locais determinam a rentabilidade das filiais, de que a qualidade institucional (ambiente legal, governança e contabilidade) determina de forma heterogênea o acesso aos mercados de capitais e de que a maturidade do sistema financeiro em cada país determina as taxas de juros praticadas e, por conseguinte, o custo de capital das subsidiárias. Neste modelo teórico proposto,

“(...) as diferenças observadas entre as unidades de negócios no que tange a produtividade, qualidade das instituições do país hospedeiro e desenvolvimento do mercado financeiro podem ampliar ou compensar as diferenças observadas nas alíquotas de tributos sobre a renda, de forma que o capital interno pode fluir em qualquer direção (Egger et al., 2014, p. 2).

Como resultado da análise deste modelo, Egger et al. (2014) demonstram que as multinacionais tendem a alocar recursos de unidades menos lucrativas em unidades com retornos acima da média do grupo, mas que atuam em localidades com acesso limitado a financiamento externo. Dentre as observações empíricas de seu estudo, se destacam as que descrevem o que diferencia grandes conglomerados domésticos das empresas multinacionais: a exposição a diferentes ambientes institucionais, o que inclui diferentes alíquotas de tributos. Defendem, ainda, que o aspecto tributário é apenas um dentre vários que determinam o fluxo dos recursos dentro de um grupo empresarial. Por exemplo, o subdesenvolvimento do mercado financeiro do país hospedeiro correlaciona-se positivamente com o índice de dívida interna da parte tomadora de empréstimos internos, enquanto que o subdesenvolvimento do mercado financeiro dos outros países em que o grupo atua apresenta correlação negativa com o mesmo índice da parte tomadora dos empréstimos internos. Em paralelo, produtividade superior da parte tomadora de empréstimos correlaciona-se positivamente com seu índice de endividamento interno, enquanto que produtividade superior das outras partes tem correlação negativa com a mesma variável, desempenhando, as alíquotas de tributos sobre o lucro, uma função sinérgica, de suporte na determinação da direção em que o endividamento interno ocorre (Egger et al., 2014, p. 4). 
Além dos determinantes institucionais e tributários ora mencionados, os mecanismos que regem os empréstimos intercompanhia funcionam também em função do mercado de capitais interno dos grupos empresariais. Prezas (2009) apresenta um amplo histórico teóricoargumentativo acerca das regras que regem o funcionamento deste mercado. Segundo o autor, se, por um lado, os mercados de capitais internos são comprovadamente relevantes no financiamento das atividades empresariais (E. F. Fama \& French, 1999; Lamont, 1997), por outro, em qualquer situação de separação entre propriedade e controle, há incentivos para a expropriação de valor por parte dos gestores da empresa (Jensen, 1986), não importando se os acionistas são matrizes localizadas fora do país. O termo empire building, portanto, consiste no termo empregado para descrever as práticas que a administração desempenha para manter seus privilégios, mesmo que envolvam políticas sub-ótimas de investimento, tomando decisões que podem não ser ótimas do ponto de vista dos proprietários. Uma das maneiras de coibir tal comportamento é o uso de dívida, que impede que gestores comprometam os lucros da empresa com projetos de baixo Valor Presente Líquido (Jensen, 1986). Conforme já mencionado, Stein (1997) coloca que o critério da "escolha do vencedor" dentro dos grupos empresariais remete à eficiência do mercado interno de capitais na alocação dos recursos disponíveis. No entanto, estudos que apresentem evidências da eficiência de mercados internos de capitais ainda são escassos (Gatzer, Hoang, \& Ruckes, 2014).

\section{Impactos esperados com a entrada de IED e EIC na economia de uma nação}

Conforme mencionado na seção introdutória deste texto, o investimento direto é composto por participação em capital e empréstimos intercompanhia, além de poder ser "brasileiro", quando o recurso tem destino fora do Brasil, ou "estrangeiro", quando investimento entra no país. A definição acadêmica corrente para IED é diversa, mas envolve, de maneira geral, a expectativa de que capital e tecnologia são introduzidos por meio de participação em uma entidade do país que recebe os recursos (Almfraji \& Almsafir, 2014).

Em 2005, o IED ainda representava mais de $60 \%$ do total de recursos privados destinados a países em desenvolvimento. Este fluxo atingiu, em anos anteriores, cifras quatro vezes maiores do que aquelas observadas nos empréstimos bancários comerciais ao final dos anos 1970 e início dos anos 1980, chegando a 320 bilhões de dólares em 1996 e pouco menos que 200 bilhões de dólares em 2000. Em 2009, o investimento total das matrizes norte-americanas 
totalizava 3,5 trilhões de dólares, sendo 207 bilhões na forma de empréstimos intercompanhia (Desai \& Dharmapala, 2015). No entanto, os efeitos deste fluxo de capitais sobre o crescimento da economia nos países que os recebem, especialmente aqueles em desenvolvimento, permanecem desconhecidos (Carkovic, 2005), embora diversos estudos tenham sido realizados com o intuito de averiguar a existência e natureza destes efeitos.

Em momentos de instabilidade econômica, depender de capital estrangeiro pode deixar o país vulnerável às intempéries da economia mundial e restringir o crescimento econômico, como foi o caso do Brasil nos anos 1990 (Carcanholo, 2002). Ainda, quanto maior for essa dependência, maior é a influência que mercados globalizados exercem sobre as taxas de juros de economias periféricas (Farhi \& Prates, 2006). Aspectos institucionais que causam distorções em preços e nos mercados financeiros e de capitais poderiam influenciar negativamente a alocação de recursos externos ou mesmo inibir sua entrada, prejudicando o crescimento econômico (Boyd \& Smith, 1992).

Em defesa da entrada de capitais estrangeiros, encontram-se argumentos como o do preenchimento de "lacunas de ideias", que representam a defasagem que países em desenvolvimento possuem em relação a países desenvolvidos no que tange a processos organizacionais e tecnologias que promovem eficiência (Romer, 1993). Neste contexto, a transferência de tecnologia, não somente para melhoria de processos, mas também para a inserção de maquinário, acompanharia, em tese, o fluxo de capitais e difundiria inovação e uso eficiente de recursos. No entanto, relatam-se evidências empíricas de correlação entre contribuição positiva da entrada do IED e condições específicas dos países, como força de trabalho altamente educada (Borensztein, Gregorio, \& Lee, 1998), riqueza (Blomstrom, Lipsey, \& Zejan, 1992), desenvolvimento do mercado de capitais (Alfaro, Chanda, Kalemli-Ozcan, \& Sayek, 2004) e abertura comercial (Balasubramanyam, Salisu, \& Sapsford, 1996), erigindo o questionamento da natureza causal destes benefícios, embora tais evidências tenham sido observadas sem a observância metodológica adequada a investigações com dados agregados macroeconômicos (Carkovic, 2005). Igualmente, Almfraji e Almsafir (2014) listam uma série de evidências disponíveis acerca da relação positiva entre IED e crescimento econômico, embora teçam críticas a respeito dos métodos empregados.

De acordo com Dritsaki e Stiakakis (2014) evidências empíricas da relação causal entre IED e crescimento econômico são inexistentes, exceto em situações específicas, como nos casos em que a economia do país hospedeiro é desenvolvida. Em sua investigação, os autores apresentam evidências de que IED não contribuiu para o crescimento econômico da economia 
da Croácia, tanto a longo quanto a curto prazo (Dritsaki \& Stiakakis, 2014). Dentre os efeitos econômicos das regras de subcapitalização, podem ser citadas as constatações de Chu (2012). Neste estudo, o autor aponta evidências de que regras rígidas de subcapitalização reduzem o incentivo para investir e são, portanto, prejudiciais ao crescimento econômico do país. Por sua vez, Buettner et al (2012) destaca-se como um dos estudos mais abrangentes em termos de amostra e resultados na avaliação dos efeitos de normas de subcapitalização. Os autores investigaram os efeitos de normas sobre a estrutura de capital de subsidiárias alemãs nos países da OCDE e outros países europeus no período de 1996 a 2004. Seus resultados não apontam para diferenças verificadas antes e após a existência de regras em um determinado país, embora termos de interação nos modelos evidenciem que, em países em que regras para subcapitalização estão presentes, há menos incentivos para a existência de empréstimos intercompanhia (Büettner et al., 2012, p. 6).

Capital humano também tem sido apontado como variável relevante na determinação dos efeitos do IED sobre o crescimento econômico nos países das ilhas do pacífico. Neste caso, observa-se relevante o fato de que existe um limite até o qual a entrada de capital externo é benéfica. Após certos limites teóricos, seu efeito sobre o crescimento pode ter sua taxa reduzida. Medidas que mitiguem os efeitos dessa limitação incluiriam uma espécie de seguro para risco político, bem como acordos que eliminem a bitributação e o combate à corrupção, que desvia receitas públicas para o setor privado, em conjunto com medidas que aumentem o desempenho do capital humano e reduzam os efeitos negativos da baixa produtividade dos negócios locais (Feeny, Iamsiraroj, \& McGillivray, 2014). Em contribuição, evidência empírica aponta para o fato de que crescimento econômico causa entrada de IED no Qatar. Neste país, o IED, parece ser mais sensível a seu próprio desempenho do que com o crescimento econômico, corroborando a tese de que, para usufruir os benefícios do IED, os países precisam, primeiro, melhorar seu desempenho econômico (Amin, Khalid, \& Yao, 2014). A investigação empírica acerca dos efeitos exercidos por investimento estrangeiro direto no Brasil ainda tem muito a avançar e apresenta, portanto, potencial elevado para o desenvolvimento de pesquisas, posto que a relação entre essas operações e o desenvolvimento de um país parece ter caráter cada vez mais endógeno (X. Li \& Liu, 2005). 


\section{Seção II - Contextos legal, tributário e contábil das regras brasileiras de subcapitalização e as regras em outros países}

\section{Contexto legal brasileiro}

A principal peça legal para referência a tributos sobre o lucro de pessoas jurídicas no Brasil é a Lei 9.430, de 27 de dezembro de 1996. Em seu artigo primeiro, essa lei determina a base (base de cálculo) sobre a qual serão calculados os valores a recolher a título de Imposto de Renda da Pessoa Jurídica (IRPJ) e de Contribuição Social sobre o Lucro Líquido (CSLL), bem como os porcentuais a serem considerados para cálculo do valor dos tributos, os quais são quinze por cento (15\%), calculados em relação ao lucro realizado no período, mais um adicional de dez por cento (10\%) em relação à parcela do lucro que exceder R $\$ 20.000,00$ (vinte mil reais) mensais para fins de IRPJ, e nove por cento (9\%) para fins de CSLL (Brasil, 1988). Este instrumento define o conceito de pessoa vinculada, o qual essencialmente, em sinergia com a lei objeto de estudo deste texto, determina os efeitos da norma brasileira de subcapitalização. Neste sentido, é considerada, quando domiciliada ou residente no exterior, pessoa vinculada à pessoa jurídica domiciliada no Brasil sua matriz, filial, sucursal, controlada, coligada, entidade sob controle conjunto, joint venture, pessoa física que mantenha, com diretores ou acionistas controladores, laços familiares de até terceiro grau e entidades que gozem de exclusividade em relacionamento comercial. Para fins deste estudo, estes aspectos foram considerados na análise dos dados e distinção entre os dois grupos de empresas, exceto a existência de parentesco até terceiro grau com diretores ou acionistas.

A apuração da base de cálculo dos tributos sobre a renda, que, dependendo da opção feita pela administração da companhia, pode ser realizada a cada trimestre ou anualmente, permite a dedução de juros como despesa necessária ao exercício do objeto social da empresa (Brasil, 1977). No entanto, com efeitos a partir do ano de 1996, a Lei 9.249 de 26 de dezembro de 1995 faculta a dedução de juros pagos também a acionistas na forma de remuneração por uso de seu capital, denominados juros sobre capital próprio (JSCP). Acionistas beneficiários são tributados, no ato do recebimento, à taxa de quinze por cento (15\%) e a taxa aplicada para cálculo dos juros deve ser inferior ou igual à Taxa de Juros de Longo Prazo (TJLP), calculada com base na rentabilidade nominal de títulos da Dívida Pública. Esta taxa era de nove por cento 
(9\%) ao ano no primeiro trimestre do ano de 2006 e cinco por cento (5\%) ao ano no último trimestre do ano de 2014.

A possibilidade de obter benefícios tributários relativos a pagamento de juros também sobre capital pode se apresentar como uma opção a mais dentre as alternativas de estrutura tributária das companhias. Tanto o pagamento dos JSCP quanto o pagamento de juros a credores vinculados no exterior estão sujeitos ao recolhimento de quinze por cento (15\%) quando do pagamento, a título de IRPJ. Na perspectiva da companhia, ambos são dedutíveis do cálculo do IRPJ e da CSLL e criam, portanto, um benefício tributário. No entanto, é possível que a TJLP seja inferior às taxas praticadas usualmente nos contratos de empréstimos intercompanhia, o que tornaria o pagamento de JSCP um benefício tributário de menor valor presente do que o do empréstimo intercompanhia. Ainda, o pagamento de JSCP condiciona-se à existência de lucros correntes ou de lucros acumulados e reserva de lucros de valor mínimo igual ao dobro dos juros a serem pagos, estabelecendo um limite à distribuição de lucros, limite este, por sua vez, vinculado à própria lucratividade da companhia. Por outro lado, em um cenário de elevação das taxas de juros, inclusive da TJLP, os JSCP podem configurar alternativa viável de distribuição de lucros, embora o pagamento de juros relativos a operações de empréstimos intercompanhia possa ocorrer mesmo com a ausência de lucros, tornando mais estáveis, sob o ponto de vista dos fluxos de caixa direcionados às partes vinculadas no exterior, as estruturas empresariais fundamentadas nas transferências por meio de empréstimos intercompanhia. Neste contexto, a distribuição de resultados por meio do pagamento de JSCP a partes vinculadas estrangeiras, as quais tendem a desempenhar papel relevante na administração de sua vinculada no Brasil, tenderia a ocorrer com maior intensidade no caso de empresas com maior lucratividade e maior concentração de propriedade, dado que o limite para o pagamento seria superior, dada a lucratividade, e a operação não estaria restrita aos limites impostos pela norma de subcapitalização brasileira, que se estabelecem a partir dos valores do endividamento com partes relacionadas. De fato, Ramb e Weichenrieder (2005) apresentam evidências de diferenças no endividamento intercompanhia entre grupos constituídos por companhias integralmente controladas por empresas estrangeiras e grupos cujas companhias são parcialmente controladas desta forma. No entanto, inexistem, no Brasil, investigações empíricas desta tendência.

Os JSCP constituem um exemplo de mecanismos que, sendo característicos do ambiente societário brasileiro, surgem em resposta a demandas reais relacionadas ao patrimônio das companhias. Ambientes inflacionários em que a figura da correção monetária integral inexiste 
requerem a possibilidade de se corrigir o capital investido a uma taxa que compense a perda inflacionária, tal qual permite a legislação que regula os JSCP, embora com algum custo tributário. Na perspectiva da parte que cede os recursos, pessoas físicas podem perceber um benefício maior do que aquele percebido por empresas, quando do recebimento de JSCP. Enquanto estas enquadrariam os proventos como receita financeira, sujeita a tributação ainda mais elevada do que os tributos sobre o lucro, aquelas teriam uma dedução de tributos sobre a renda menor do que a esperada para pessoas físicas no Brasil.

Poucos estudos investigam os efeitos dos JSCP sobre fenômenos relacionados a tributação e estrutura de propriedade. Em uma abordagem de estudo de caso, Veiga, Imbrosio e Ferreira (2007) verificam que, embora o pagamento de JSCP reduza a carga tributária da companhia, os acionistas não ficam em melhor situação, dado que estes repasses podem, em conformidade com a lei, ser imputados ao cálculo de dividendos, reduzindo o montante destes e, portanto, onerando a distribuição de resultados. Ainda, a dedução dos JSCP, ao reduzir a base de cálculo dos dividendos obrigatório, torna o valor destes ainda menor, reduzindo a renda do acionista, podendo ter impactos sobre o valor da empresa. A existência de diferentes naturezas jurídicas no grupo de acionistas determina propensões de distribuição direta de lucros. Colombo e Terra (2012) apresentam evidências de que a existência de investidores institucionais na estrutura de controle faz com que os padrões de distribuição de lucro tendam para o formato de JSCP, em detrimento dos dividendos. Embora pareça contraditório, dado que a receita de juros deve ser tributada, esta influência dos investidores institucionais parece, na visão dos autores, ser função do fato de que, frequentemente, estes investidores são entidades fechadas de previdência complementar, que, mesmo sem exercer controle, contam com significativa influência sobre a administração.

Futema et al. (2009) relatam correlação observada entre distribuição de lucros, variação no grau de investimentos e alavancagem em empresas brasileiras, tendo incluído os valores de JSCP na variável que denota a distribuição de lucros. No entanto, os autores não extendem suas conclusões à avaliação do efeito diferencial que a distribuição de lucros por meio do pagamento de JSCP apresenta sobre a estrutura de capital em relação a situações em que esta distribuição não é possível, como, por exemplo, o caso de empresas estabelecidas nos Estados Unidos da América (EUA). Segundo Brito, Lima e Silva (2009), a distribuição direta de resultados, que não é comum na América do Norte, aumentou, no Brasil, 50\% no período entre 1997 e 2003, embora, em comparação com os EUA, a distribuição brasileira de lucros seja reduzida. Os autores atribuem essa diferença ao pagamento de JSCP. Em seu estudo, encontram evidências 
de que as diferenças entre empresas dos dois países, no que tange à distribuição de resultados, são determinadas principalmente por incentivos tributários que empresas brasileiras percebem para tal prática, ao contrário de que, no país estrangeiro, as empresas passaram por alterações em suas características fundamentais, levando a mudanças nos padrões de distribuição de lucros. No entanto, não existem estudos que investiguem, no Brasil, o papel que a distribuição direta de lucros desempenha nas relações intercompanhia, em especial a sinergia ou antagonismo que ela representa em relação a empréstimos intercompanhia.

A divulgação das condições das operações intercompanhia tem sido objeto de regras de evidenciação contábil no Brasil. Preços de transferência, montantes contratados na forma de empréstimos, seus prazos e taxas de juros constituem informações relevantes, dado que afetam os resultados da empresa, seja em função dos benefícios que geram, seja em função dos custos e riscos que representam, tais quais custos financeiros, de agência ou de falência.

O Comitê de Pronunciamentos Contábeis (CPC), em seu Pronunciamento Técnico CPC 05 (CPC 05), busca assegurar que

... as demonstrações contábeis da entidade contenham as divulgações necessárias para chamar a atenção dos usuários para a possibilidade de o balanço patrimonial e a demonstração do resultado da entidade estarem afetados pela existência de partes relacionadas e por transações e saldos, incluindo compromissos, com referidas partes relacionadas (CPC, 2010).

Este pronunciamento visa ao provimento de padrões para a evidenciação da existência de operações com partes relacionadas, seus valores e suas circunstâncias, enfatizando que partes relacionadas podem obter benefícios em transações que, por outras vias, não obteriam, tais como custos e valores de operações comerciais. O CPC divulgou o CPC 05 em 07 de outubro de 2010, quatro meses após a conversão da Medida Provisória 472/2009 na Lei 12.249/2010, que define as normas de subcapitalização no país. No entanto, este pronunciamento contábil não determina o fornecimento de informações referentes aos critérios de dedutibilidade de despesas de juros estabelecidos pelas normas brasileiras de subcapitalização ou à evidenciação contábil do efetivo benefício fiscal ou financeiro de cada operação. Dessa forma, as informações que constam nas Demonstrações Financeiras são os valores dos empréstimos obtidos com partes relacionadas e os valores devidos resultantes de transações comerciais, ambos registrados no Passivo Circulante e no Passivo não Circulante do Balanço Patrimonial, respectivamente. As Notas Explicativas, por sua vez, podem conter informações acerca dos mutuantes, se são partes vinculadas, bem como taxas e prazos dos contratos e suas respectivas participações societárias no mutuário, mas tal evidenciação não é compulsória. 
Por outro lado, operações intercompanhia já são objeto de regulação há várias décadas. O registro do capital estrangeiro que ingressa no Brasil está previsto na Lei 4.131, de 3 de setembro de 1962, Parágrafo $3^{\circ}$, alínea $a$, bem como na Lei 11.371 de 28 de novembro de 2006. A Lei 4.131 foi regulamentada pelo Decreto 55.762, de 17 de fevereiro de 1965. Esta lei determina, em seu artigo 21, a obrigatoriedade de evidenciação da participação em capital ou dívida para com entidades estrangeiras:

Art. 21. É obrigatória, nos balanços das empresas, inclusive sociedades anônimas, a discriminação da parcela de capital e dos créditos pertencentes a pessoas físicas ou jurídicas, residentes, domiciliadas ou com sede no exterior, registrados na Superintendência da Moeda e do Crédito.

Art. 22. Igual discriminação será feita na conta de lucros e perdas, para evidenciar a parcela de lucros, dividendos, juros e outros quaisquer proventos atribuídos a pessoas físicas ou jurídicas, residentes, domiciliadas ou com sede no estrangeiro cujos capitais estejam registrados na Superintendência da Moeda e do Crédito (Brasil, 1962).

Estes dispositivos legais estabelecem, dentre outras coisas, também o registro das remessas de juros e amortizações ao exterior e "da prova de pagamento do impôsto (sic) de renda que for devido" (Brasil, 1965, Art. $3^{\circ}$, alínea $e$, par. $3^{\circ}$ ). Além da evidente preocupação do legislador quanto ao pagamento de tributos sobre a renda em operações de transferência de juros, verifica-se também a atenção dada ao equilíbrio das contas do Balanço de Pagamentos, conforme Artigo 28 da Lei 4.131:

Art. 28. Sempre que ocorrer grave desequilíbrio no balanço de pagamento ou houver sérias razões para prever a iminência de tal situação, poderá o Conselho da Superintendência da Moeda e do Crédito impor restrições, por prazo limitado à importação e às remessas de rendimentos dos capitais estrangeiros e para êste fim outorgar ao Banco do Brasil monopólio total ou parcial das operações de câmbio.

$\S 1^{\circ}$ No caso previsto neste artigo, ficam vedadas as remessas a título de retôrno de capitais e limitada a remessa de seus lucros, até $10 \%$ (dez por cento) ao ano, sôbre o capital e reinvestimentos registrados na moeda do país de origem nos têrmos dos $\operatorname{artigos} 3^{\circ}$ e $4^{\circ}$ desta lei.

$\S 5^{\circ}$ Não haverá, porém, restrições para as remessas de juros e quotas de amortização, constantes de contrato de empréstimo, devidamente registrados (Brasil, 1962).

Antes do Banco Central do Brasil entrar em atividade, o registro do ingresso de capitais estrangeiros era realizado pela SUMOC - Superintendência da Moeda e do Crédito, onde todas as "remessas feitas para o exterior com o retorno de capitais ou como rendimento desses capitais, lucros, dividendos, juros, amortizações, bem como as de 'royalties', ou por qualquer 
outro título que implique transferência de rendimentos para fora do país" (Brasil, 1962) seriam realizadas. A Lei 11.371/06, em seu Art. 5º, estabelece que o registro de participações em capital se dá com o Banco Central do Brasil, enquanto que se encontra previsto o registro dos empréstimos intercompanhia no Artigo $1^{\circ}$, primeiro parágrafo, inciso II da Resolução N. 3.844 do Banco Central do Brasil (B. C. do Brasil, 2010), e é regulamentada no âmbito do Banco Central do Brasil pela Circular N. 3.689 de 13 de dezembro de 2013 (B. C. do Brasil, 2013). Conforme Anexo II da Resolução N. 3.844, todo crédito externo concedido, em moeda ou bens, a pessoa jurídica residente, domiciliada ou com sede no país, por pessoa física ou jurídica, residente, domiciliada ou com sede no exterior, deve ser registrado no Sistema de Informações do Banco Central (Sisbacen) - Registro Declaratório Eletrônico (RDE) em até 30 dias da data do evento que lhe deu origem. Operações sujeitas a este procedimento incluem, dentre outras, os empréstimos externos, com ou sem emissão de títulos e financiamento e arrendamento financeiro mercantil externos, desde que tenham prazo superior a 360 dias. De acordo com informações do site do Banco Central do Brasil, os dados da...

(...) conta capital e financeira são compilados com base nas operações de câmbio realizadas nas instituições autorizadas a operar no mercado de câmbio, considerando, também, as transações em moeda nacional realizadas entre residentes e não residentes. Essas operações são compulsoriamente registradas no Sistema de Informações Banco Central (Sisbacen-Câmbio). Adicionalmente, são consideradas informações provenientes de pesquisas em empresas privadas, relatórios de órgãos governamentais e dos balancetes de instituições financeiras (BCB, 2016 https://www.bcb.gov.br/pec/sdds/port/balpagam_p.htm).

Por meio destes procedimentos, o governo brasileiro obtém os dados que compõem a conta financeira do Balanço de Pagamentos, segregando os valores em Investimentos de Capital e Empréstimos Intercompanhia. A variação temporal destas contas constituem a principal motivação deste estudo.

Antes da Lei 12.249 de 2011, as regras brasileiras de apuração do imposto de renda já restringiam a dedutibilidade do pagamento de juros realizado a partes vinculadas domiciliadas no exterior. Mesmo antes do advento da mencionada norma de subcapitalização, já se condicionava o pagamento de juros a partes relacionadas, onde quer que fossem residentes ou domiciliadas, à inexistência de lucros não disponibilizados nos balanços de partes relacionadas no exterior. Conforme o parágrafo terceiro da lei 9.532 de 10 de dezembro de 1997, 
ou creditados a empresa controlada ou coligada, independente do local de seu domicílio, incidentes sobre valor equivalente aos lucros não disponibilizados por empresas controladas, domiciliadas no exterior (Brasil, 1997).

Ainda, segundo a Lei 9.430 de 27 de dezembro de 1996,

Art. 22. Os juros pagos ou creditados a pessoa vinculada somente serão dedutíveis para fins de determinação do lucro real até o montante que não exceda ao valor calculado com base em taxa determinada conforme este artigo acrescida de margem percentual a título de spread, a ser definida por ato do Ministro de Estado da Fazenda com base na média de mercado, proporcionalizados em função do período a que se referirem os juros (Brasil, 1996).

No entanto, o teor destes textos legais não observa a estrutura de capital da empresa mutuária residente no Brasil, atendo-se ao valor dos juros pagos à parte relacionada domiciliada no exterior. Nestas condições, a norma em análise, que condiciona a existência de benefício tributário à estrutura de capital das companhias, pode exercer efeito empiricamente identificável por meio da observação das tendências de endividamento de empresas multinacionais. Ainda, Vicentini (Vicentini, 2014) reporta a inexistência de tais critérios, relacionados à estrutura de capital, antes do ano de 2009. Adicionalmente, a lei 9.430/96 fixou, em sua redação original, uma taxa de juros a ser usada como referência no cálculo dos valores considerados excedentes e indedutíveis da base de cálculo do IRPJ e CSLL, além de estabelecer a obrigatoriedade do uso desta referência somente para os contratos de empréstimo não registrados no Banco Central. No caso dos contratos registrados, seria admitida a taxa informada no contrato, criando uma distorção no tratamento de diferentes contratos. Estes dois aspectos foram corrigidos pela Medida Provisória 563 de 3 de abril de 2012, convertida na Lei 12.715 de 17 de setembro de 2012 (Brasil, 2012a, 2012b), ao estabelecer critérios mais flexíveis para o cálculo da taxa de referência e ao eliminar a exceção a que estavam sujeitos os contratos registrados no Banco Central.

As normas de subcapitalização propriamente ditas, que introduzem critério diferente para classificar como indedutíveis juros pagos a partes relacionadas domiciliadas no exterior, foram emitidas sem prejuízo das leis anteriores. Portanto, além da restrição estabelecida a partir da relação entre dívida e Patrimônio Líquido, mantêm-se as restrições existentes com relação ao valor dos juros pagos e a obrigação de observar a existência de lucros retidos com partes relacionadas no exterior. Ainda, mesmo que o endividamento esteja dentro dos limites 
permitidos pela norma de subcapitalização, a taxa limite para se considerarem dedutíveis os pagamentos de juros devem ser observada. Esta taxa é a taxa:

I - de mercado dos títulos soberanos da República Federativa do Brasil emitidos no
mercado externo em dólares dos Estados Unidos da América, na hipótese de
operações em dólares dos Estados Unidos da América com taxa prefixada;
II - de mercado dos títulos soberanos da República Federativa do Brasil emitidos no
mercado externo em reais, na hipótese de operações em reais no exterior com taxa
prefixada; e
III - London Interbank Offered Rate - LIBOR pelo prazo de 6 (seis) meses, nos
demais casos (Brasil, 1996, Art. 22, Parágrafo $6^{\circ}$ ).

Entretanto, existem outras interpretações legais concernentes à taxa máxima de contratos de empréstimo no Brasil. Vicentini (Vicentini, 2014), por exemplo, cita que a taxa pode ser igual à taxa básica de juros, ao dobro desta taxa ou, ainda, 12\% ao ano. Não é objetivo deste estudo avaliar jurisprudência nesta área e a divergência doutrinária existente sobre o tema.

Em 11 de dezembro de 2009, foi submetido à apreciação do então Presidente da República do Brasil o Projeto de Medida Provisória que, dentre outras coisas, "aprimora a legislação tributária vigente eliminando algumas formas abusivas de planejamento fiscal" (Brasil, 2011). O item 29 da Exposição de Motivos Interministerial (EMI) descreve a preocupação em evitar a erosão da base de cálculo do Imposto de Renda Pessoa Jurídica (IRPJ) e da Contribuição Social sobre o Lucro Líquido (CSLL), especialmente por meio do estabelecimento, no Brasil, de subsidiárias subcapitalizadas e altamente endividadas para fins de obtenção de benefício com a dedução dos juros pagos a partes relacionadas no exterior. Tais dispositivos legais visam a reduzir ou eliminar a distribuição disfarçada de lucros (DDL), caracterizada nos termos do Artigo 464 do RIR/1999, cuja redação foi dada pelo Artigo 60 do Decreto-Lei n ${ }^{\circ} 1.598$, de 1977, e pelo Artigo 20, inciso II do Decreto-Lei n ${ }^{\circ} 2.065$, de 1983. De forma geral, a DDL é caracterizada quando, ao transacionar com partes relacionadas, uma companhia obtém alguma vantagem que não seria obtida se realizasse a mesma operação com terceiros. Tais vantagens são obtidas por meio do estabelecimento de condições diferenciadas, como menor preço, maior prazo, perdão de dívida, extinção de garantia, etc... (Vicentini, 2014). Inexistem determinações legais para a evidenciação objetiva de tais vantagens nas demonstrações financeiras. No entanto, referências a sua existência podem ser observadas e exemplificam-se com o Anexo A.

Empréstimos intercompanhia proporcionariam uma economia em impostos de, no mínimo, 19\% do valor dos juros pagos. O benefício tributário apresenta esta monta no caso de retenção dos tributos na fonte, quando $15 \%$ das remessas para pagamento de juros no exterior 
devem ser retidos, considerando-se $34 \%$ do valor total dos juros deduzidos o benefício potencial máximo (Pedrosa Junior, 2014; Vicentini, 2014), obtido com a existência de qualquer tipo de endividamento.

A título de ilustração, uma companhia que possui, em determinado ano, Lucro antes dos Juros, Imposto de Renda e Contribuição Social Sobre o Lucro Líquido no valor de $\$ 800.000,00$, despesa de juros de dívida bancária no valor de $\$ 90.000,00$ reais e despesa juros de dívida com sua matriz no exterior no valor de $\$ 50.000,00$ reais deduzirá um total de $\$ 140.000,00$ reais da base de cálculo dos tributos. Dos $\$ 660.000,00$ reais remanescentes, a companhia deverá recolher 34\%, equivalentes à soma do Imposto de Renda, Contribuição Social Sobre o Lucro Líquido e do adicional de $10 \%$ sobre a parcela do lucro que exceder o valor de $\$ 240.000,00$ reais. O valor total dos tributos é de $\$ 266.400,00$ reais, remanescendo $\$ 393.600,00$ reais de lucro após tributos.

Se a companhia optasse por substituir o financiamento intercompanhia por recursos próprios, incorreria no pagamento de $\$ 17.000,00$ reais a mais de impostos, pois não deduziria o pagamento de juros. Alternativamente, caso optasse por substituir com financiamento externo no país, teria o mesmo benefício tributário da dívida intercompanhia, mas incorreria em outros custos, como de agência e falência e não recolheria tributos no ato do envio dos juros para o exterior. Neste caso, mantendo o endividamento intercompanhia estrangeiro, ao enviar os recursos para sua matriz no intuito de realizar o pagamento dos juros, a tributação ocorre "na fonte", à alíquota de 15\%, reduzindo o benefício tributário. Dessa forma, evitou-se o pagamento de $\$ 17.000,00$ reais de tributos em comparação com o financiamento com capital próprio, mas, ao enviar o pagamento dos juros à parte relacionada no exterior, são recolhidos $\$ 7.500,00$ (15\% de \$50.000,00), não havendo o pagamento da CSLL e resultando em benefício líquido de $\$ 9.500,00$, ainda em comparação com o financiamento com capital próprio. Em termos relativos, o benefício máximo seria uma economia tributária de $34 \%$ do valor dos juros pagos $(\$ 17.000,00)$ e, o benefício mínimo, uma economia tributária de $19 \%$ dos juros pagos $(\$ 9.500,00)$, quando do envio dos valores à matriz no exterior. Portanto, com o estabelecimento de regra que limite a dedutibilidade de juros para empresas mais endividadas com partes relacionadas, reduzem-se os incentivos financeiros para o endividamento excessivo dessa natureza, ou seja, para a subcapitalização conforme definida na exposição de motivos da lei em questão.

O texto final da lei que regula subcapitalização no Brasil afeta todas as empresas que possuem dívidas com partes relacionadas no exterior. Conforme este texto, 
Art. 24. (...) os juros pagos ou créditos por fonte situada no Brasil à pessoa física ou jurídica, vinculada (...), residente ou domiciliada no exterior, (...) somente serão dedutíveis, para fins de determinação do lucro ou da base de cálculo da Contribuição Social sobre o Lucro Líquido, quando se verifique constituírem despesa necessária à atividade (...), atendendo aos seguintes requisitos:

I - (...) com pessoa jurídica vinculada no exterior que tenha participação societária na pessoa jurídica residente no Brasil, o valor do endividamento com a pessoa vinculada no exterior, (...), não seja superior a 2 (duas) vezes o valor da participação da vinculada no patrimônio líquido da pessoa jurídica residente no Brasil;

II - (...) com pessoa jurídica vinculada no exterior que não tenha participação societária na pessoa jurídica residente no Brasil, o valor do endividamento com a pessoa vinculada no exterior, (...), não seja superior a 2 (duas) vezes o valor do patrimônio líquido da pessoa jurídica residente no Brasil;

III - (...) (Brasil, 2010)

Portanto, da mesma forma que as filiais subcapitalizadas no Brasil, também as matrizes brasileiras que tomam empréstimos de filiais no exterior estão sujeitas a essa regra, enquadrando-se no item II do Artigo 24 da Lei. Dada a possibilidade de que esta norma também produza efeitos sobre as decisões de financiamento das matrizes brasileiras que possuem dívidas com partes relacionadas no exterior, a amostragem neste estudo seguiu um método que permita incluir também empresas cujo controle seja exercido por partes residentes ou domiciliadas no Brasil.

A Medida Provisória que apresentou as normas correntes de subcapitalização no Brasil, de número 472, foi publicada em 15 de dezembro de 2009 e convertida em lei em 11 de junho de 2010. A Receita Federal do Brasil (RFB) emitiu a Instrução Normativa IN 1.154 em 12 de maio de 2011, regulamentando a matéria e fornecendo metodologia de cálculo do valor dos juros classificados como não dedutíveis na apuração do IRPJ e CSLL, cálculo este que deve ser realizado mensalmente. Estes juros, considerados não dedutíveis, devem ser adicionados ao lucro tributável anual ou trimestral (R. F. do Brasil, 2011).

No que tange aos efeitos da lei sobre o cálculo do IRPJ, a Constituição Federal do Brasil prevê, em seu Artigo 150, inciso III, alínea $a$, que é vedado cobrar tributos no mesmo exercício financeiro em que foi publicada a lei que os instituiu ou aumentou, o que se conhece como princípio da anterioridade. Com relação à CSLL, o Artigo 195, parágrafo sexto, prevê que contribuições para a seguridade social não podem ser cobradas antes de 90 dias após a publicação da lei que as instituiu ou modificou, o que se conhece como noventena ou princípio da anterioridade nonagesimal.

Ainda, em casos de majoração de tributos sobre a renda, como é o caso dos Artigos 24 e 25 da Lei, em função do fato de que a restrição à dedutibilidade se deu por meio de Medida Provisória, o Artigo 62, parágrafo segundo da Constituição Federal do Brasil, prevê que, não 
tendo sido a Medida Provisória convertida em lei no mesmo ano de sua edição, a lei só produzirá efeitos no ano seguinte ao de sua promulgação. No caso em questão, uma Medida Provisória de 2009 foi convertida em lei em 2010 e, portanto, a lei tem eficácia somente a partir do exercício de 2011. O mesmo não se aplica à CSLL, estando sujeita ao princípio da anterioridade nonagesimal. Portanto, no que tange à CSLL, a lei tem efeito a partir de 12 de setembro de 2010, ou seja, 90 dias após a promulgação da lei.

\section{As normas em outros países}

Se, por um lado, multinacionais adotam a subcapitalização como forma de realização de investimentos em outros países, por outro os países tornam cada vez mais rígidas as normas para a subcapitalização para evitar a fuga de capitais. A partir de uma perspectiva doutrinária, operações entre empresas deveriam ter outros objetivos que não a minimização dos tributos incorridos, fazendo valer o que se convenciona denominar princípio da essência sobre a forma (Webber, 2010b). Nesta perspectiva, os tributos que resultam de uma operação negocial não devem ser observados apenas no contexto formal da realização do negócio, mas sim a partir da natureza fundamental da circulação de ativos (Lessambo, 2009).

Os principais direcionamentos das políticas elaboradas para reduzir a prática de subcapitalização são o incentivo ao padrão arm's length e o estabelecimento de limites ao endividamento por meio de quocientes debt-to-equity. Enquanto o primeiro estabelece que, mesmo em transações intercompanhia, espera-se que ambas as partes ajam conforme o seu interesse individual (Jones, Cline, \& Ryan, 2006), o segundo consiste, por exemplo, da regra adotada pela norma brasileira, que determina um endividamento máximo em relação a algum critério concernente à situação patrimonial existente entre as partes. Países como a Alemanha, Itália, Holanda e o Reino Unido têm realizado modificações em suas normas de subcapitalização, empregando um critério ou outro em maior evidência, no intuito de corrigir ou elevar sua eficácia. No entanto, conforme Webber (Webber, 2010b) descreve, mudanças frequentes podem refletir a dificuldade de desenhar regras eficientes e, em geral, o limite ao endividamento não tem funcionado como se espera. Ao emitir suas próprias regras, explicitamente limitando o endividamento e estabelecendo um critério relacionado ao patrimônio da firma, a legislação brasileira passa a aplicar um critério que já era reconhecidamente empregado em outros países apenas com relativo sucesso, ainda que regras 
para a dedutibilidade do pagamento nomeadamente "excessivo" de juros já se encontrassem em vigor e com efeitos, erigindo a possibilidade de se questionar a utilidade e possibilidade que as normas mais recentes possuem de exercer algum efeito diferencial, especialmente em função do fato de que "é simples, para multinacionais, elevar o Patrimônio Líquido das subsidiárias financiadas para acomodar tanta dívida quanto for necessário" (Vicentini, 2014).

Webber (2010b) apresenta uma compreensiva análise comparativa de normas de subcapitalização elaboradas em diversos países. Segundo este autor, as normas norte americanas foram inicialmente implantadas em 1989, fundamentadas em dois critérios: (i) a razão entre dívida e patrimônio, que não deveria exceder o valor de 1,5, e, adicionalmente, (ii) a despesa de juros não deveria exceder em cinquenta por cento (50\%) o valor do lucro ajustado da companhia. Quando não cumpridos estes dois critérios, o valor excedente aos $50 \%$ mencionados seria considerado não dedutível para fins de tributos sobre o lucro, admitindo, portanto, a possibilidade de envio de lucros para fora do país na forma de juros pagos a partes relacionadas, desde que o limite de 1,5 não seja ultrapassado. Esta regra tem critérios similares aos da regra brasileira, bem como guarda semelhanças com a regra alemã. Até o ano de 2003, conforme Webber (op. cit.), a Alemanha possuía regras que também incluíam a razão entre dívida com partes relacionadas estrangeiras e capital próprio, a qual podia ser de 3,0 para holdings ou 1,5 para outras empresas. No entanto, a legislação alemã foi questionada pela European Court of Justice em função de empregar tratamentos diferenciados para dívida com terceiros em relação a dívidas com partes relacionadas oriundas do exterior. A lei tributária alemã poderia reclassificar proporções distintas dos pagamentos de juros, se comparados aquele dirigidos a partes relacionadas aos direcionados a terceiros, tratando-as como dividendos ou, ainda, tributando os dividendos reclassificados a alíquotas distintas quando o favorecido consiste de empresa ou pessoa estrangeira. Tais questionamentos, bem como o fato de que o critério da razão entre dívida e capital próprio nem sempre elimina a distribuição excessiva de lucros por meio de dívidas, levaram os legisladores alemães a modificar suas normas, tratando o endividamento como um todo e estipulando um limite de dedutibilidade no valor de trinta por cento $(30 \%)$ dos lucros antes dos juros, tributos, depreciações e amortizações para todas as companhias. Algumas exceções se aplicam, em especial ao se comparar o endividamento relativo de uma companhia específica ao endividamento geral do grupo a que ela pertence. Webber (Op. cit.) considera que esta regra elimina muitos dos problemas que surgem quando do uso dos safe haven ratios, mas que não elimina totalmente a existência do tratamento diferenciado, dado que, no caso de uma empresa alemã que possui uma subsidiária alemã, 
ambas localizadas na Alemanha, a situação pode ser tratada como uma unidade de negócios, enquandrando-se no conceito de exceção à regra e não estando sujeita ao limite de $30 \%$. Por outro lado, se a companhia matriz fosse estrangeira, o limite se aplicaria.

A mesma situação de tratamento diferenciado ocorria no Reino Unido até o ano de 2004. Nesta região econômica, empresas que pagavam juros a partes relacionadas localizadas no exterior estavam em situação de desvantagem em relação a empresas que os pagavam a terceiros. No intuito de igualar o tratamento dado a essas situações, os legisladores passaram a elaborar regras que exigiam o cálculo da capacidade de endividamento de uma empresa sob o princípio do arm's length, ou seja, quanto de dívida e a que custo uma companhia obteria se buscasse recursos com instituições não relacionadas a seu grupo econômico. Deduções de pagamentos de juros por conta de dívidas que excedessem este valor não seriam aceitas para fins de cálculo de tributos sobre o lucro.

Conforme Webber (Op. cit.), este critério apresenta dois problemas relevantes. O primeiro consiste do fato de que determinar, hipoteticamente, o valor das dívidas que uma companhia poderia ter representa uma situação complexa, dado que empréstimos são concedidos por meio de análises criteriosas e negociações extensas. Segundo, em função disso, normas que obriguem obediência a esta prática podem não surtir efeito. No entanto, o critério do arm 's lenght é tido como justo pela literatura, embora $88 \%$ das empresas inglesas guardem, em função de suas estratégias de negócios, capacidade extra para obter empréstimos adicionais com terceiros sem elevar seus custos de transação (Allen, 2000), tornando esta lógica empregada no Reino Unido uma espécie de autorização de endividamento para fins tributários.

A partir do ano de 2010, a legislação passou a considerar não dedutíveis os pagamentos de juros intercompanhia que, realizados no Reino Unido, excedem o total de juros pagos a terceiros em todos os países em que a companhia atua. Este critério, semelhante aos que são aplicados na Alemanha e Japão, país cuja legislação demanda a comparação do endividamento com aquele de companhias semelhantes, consiste em procedimento menos arbitrário e mais justo, posto que diferentes companhias podem ter diferentes estratégias corporativas quanto a endividamento (Webber, Op. Cit.). No entanto, há evidências empíricas de que estabelecer um procedimento que empregue debt-to-equity ratios poderia encorajar empresas a usar dívida intercompanhia para fins tributários, se tivessem elas, antes da existência de tal norma, adotado estratégia de baixo endividamento. Por exemplo, no Canadá, país em que apenas 7,1\% das companhias possuíam dívidas acima do limite estabelecido (Farrar \& Mawani, 2008). 
Além do Canadá, também Itália, França e Japão possuem ou possuíram normas para subcapitalização com base nos debt-to-equity ratios. Tal qual na norma brasileira, os juros relacionados ao valor excedente não são dedutíveis para fins de tributos sobre o lucro. Esta prática, além de poder ser considerada injusta por empresas que empregam maiores proporções de dívida em suas operações, não limita o valor absoluto que pode ser deduzido, portanto, não impondo limites absolutos ao valor dos juros e, consequentemente, do benefício tributário.

Webber (2010b) analisa o funcionamento de normas para subcapitalização em outros países, como Dinamarca, Holanda e Nova Zelândia, que também empregam o critério do debtto-equity ratio, bem como outras normas específicas a cada país. Estas podem incluir teste de ownership, que enquadram a aplicabilidade da norma em função da concentração da propriedade, e a possibilidade de não se sujeitar à limitação em função de ter o debt-to-equity ratio da subsidiária inferior ao verificado no grupo econômico (p. 701). Por outro lado, países menores, por não possuírem tantos contribuintes quanto os maiores, podem ter uma perspectiva diferente quanto à subcapitalização. Haufler e Runkel (2008) assertam que estes países podem tanto possuir baixas taxas de tributos sobre a renda quanto normas de subcapitalização mais lenientes, no intuito de atrair investimentos. Webber ( $O p$. cit.) analisa a legislação de oito países europeus, enquadrados nessas condições, quanto às normas de subcapitalização e cita que metade deles, Chipre, Estonia, Irlanda e Malta, não as possui e, além disso, possuem alíquotas de imposto sobre o lucro variando entre $10 \%$ e $35 \%$, sendo 19,66\% a média. Os outros países, que possuem normas, apresentam debt-to-equity ratios de, no mínimo, 4 para 1, configurando normas consideravelmente mais flexíveis (p. 702).

A norma brasileira estabelece um parâmetro semelhante ao empregado por outros países que adotam os limites de endividamento ao verificar a dedutibilidade da despesa com juros. Estes critérios são empregados de forma indiscriminada a todas as empresas, que devem se sujeitar, independentemente de suas estratégias em relação ao uso de capital de terceiros, aos limites preconizados pela norma. Esta abordagem, conforme descrito por Webber (2010a), não tem se mostrado suficiente para evitar a distribuição de lucros na forma de juros, pois que empresas menos endividadas poderiam endividar-se com seus controladores e obter o benefício tributário previsto pela lei, até o limite estabelecido. Nos casos da Alemanha e Itália, esta regra foi acompanhada por outras normas que abordavam de forma distinta capital oriundo de fora do país em relação a capital interno, não sendo, portanto, neutra. No entanto, a norma brasileira consiste de um critério diferente, ao considerar, como denominador no cálculo do debt-equity ratio, apenas o valor que a cedente estrangeira de recursos possui no patrimônio da tomadora 
de recursos e, quando este valor for zero, apenas a parcela que possuem todas as partes relacionadas, nacionais e estrangeiras, no patrimônio da tomadora dos fundos, enquanto que as normas descritas por Webber (Op. Cit) consideram todo o patrimônio líquido da empresa como referência. Apesar desta diferença, que pode ou não surtir efeitos distintos daqueles observados em países com normas semelhantes, a regra brasileira busca elevar a arrecadação de tributos sobre o lucro por meio do exercício de influência sobre a estrutura de capital das empresas, desconsiderando que este aspecto pode configurar elemento estratégico na condução dos negócios.

Este formato tem sido criticado, dado que não conduz aos resultados esperados, os quais consistem, especialmente, do aumento da arrecadação (Farrar \& Mawani, 2008; Seida \& Wempe, 2004). Webber (Op. Cit., p. 707) propõe, portanto, um modelo fundamentado na limitação das despesas de juros, tendo, como referência, o valor global dos lucros antes de juros, tributos, depreciações e amortizações das operações totais do grupo empresarial. Este critério seria mais adequado em função de que provê certeza da dedutibilidade, é justo para com as empresas que têm diferentes estratégias quanto a endividamento e é neutro quanto à origem do capital empregado. Neste cenário, decisões tomadas no âmbito do grupo determinariam a referência para a dedutibilidade dos juros pagos por subsidiárias, tornando a apuração dos tributos mais fácil e previsível para todas as partes envolvidas, bem como contribuiria para a prevalência da essência dos negócios sobre a forma neles empregada e para a normalização dos efeitos dos tributos sobre todo o grupo empresarial. A norma brasileira não apresenta qualquer semelhança com este critério. De fato, ela não estabelece valores absolutos aos limites de dedutibilidade, permitindo, ao contrário de impedir, que empresas menos endividadas possam distribuir lucros ao usufruir de benefícios tributários com novo endividamento intercompanhia. Ainda, embora a legislação brasileira mantenha provisões quanto ao uso indiscriminado de despesas que podem ser classificadas como não necessárias ao desempenho do objeto social de uma organização, não existem menções a qualquer restrição de dedutibilidade de juros pagos por uso do capital de terceiros, ou seja, de partes não relacionadas. Esta situação, perpetuada pela lei que define as normas brasileiras de subcapitalização, permite a substituição do endividamento intercompanhia em excesso por empréstimos externos, com pagamentos de juros dedutíveis, não exercendo, portanto, efeitos nas receitas tributárias do país. 


\section{Seção III - Método e dados}

\section{O problema de pesquisa}

A investigação busca encontrar evidências de alterações na estrutura de capital das empresas brasileiras que possuem partes vinculadas estrangeiras após o advento das regras de subcapitalização no país, motivação que decorre da orientação que se imbuiu a essas normas. O principal objetivo constituiu-se da identificação de uma reação provocada pela promulgação da referida lei. Portanto, a comparação de dois grupos em dois momentos distintos, antes e após a vigência da norma para subcapitalização, constitui a principal orientação para a escolha do método aplicado para identificar a relação causal buscada. Entende-se que a identificação do efeito advém do desenho da pesquisa, de sua capacidade de tanto isolar o efeito do "tratamento" quanto de controlar os efeitos de elementos não observados. Antes que à ferramenta estatística empregada, a causalidade está relacionada à lógica da investigação realizada, que impõe restrições e verifica a existência de relações (Pilati \& Laros, 2007).

Experimentos do tipo "ideal" avaliam a diferença entre as respostas de dois grupos, doravante "tratamento" e "controle", a uma intervenção. O desafio a ser suplantado quando não é possível controlar ou manipular as condições em que uma intervenção ocorre é a impossibilidade de se observarem os efeitos de sua não aplicação ao grupo e, consequentemente, a inexistência de uma referência que permita a observação real do efeito do tratamento em questão. Em procedimentos desta natureza, é necessário certificar que os grupos são comparáveis de tal forma a se aproximarem do contrafactual um do outro, o que implica em que os dados coletados acerca do fenômeno devem atender a certas premissas do método usado para identificar os efeitos investigados, caso o controle sobre as condições nas quais a intervenção ocorre não seja possível. Havendo a possibilidade de se certificar de que outros fatores, observados ou não, têm efeitos sobre os dois grupos da mesma forma, é possível identificar o efeito da intervenção sobre o resultado observado no grupo tratamento.

Estudos em ciências sociais aplicadas que examinam resultados de intervenções em sujeitos pertencentes a grupos de "tratamento" e grupos "controle", em que a designação dos sujeitos a um dos dois grupos não é realizada de forma aleatória por meio da intervenção do pesquisador, têm sido denominados "experimentos naturais". Na área da Psicologia, são chamados "quasi-experimentos", dado que não constituem experimentos aleatórios de fato. A 
importância da aleatoriedade na designação dos sujeitos aos grupos reside no fato de que, tendo sido essa designação aleatória, ou seja, não existindo correlação entre "receber o tratamento" e qualquer uma das características da população, a resposta à intervenção, observada no grupo "tratamento", resulta da intervenção.

Um dos principais aspectos do experimento natural é a comparabilidade entre os dois grupos, que podem ser, especialmente em ciências sociais, diferentes entre si. As estratégias de identificação correntemente empregadas possuem premissas que, por exemplo, permitem a comparação entre grupos distintos a partir da constatação de tendências similares, antes da intervenção, das variáveis resposta dos grupos. Define-se "diferença" entre os grupos aquelas observadas de forma direta ou não, tais como volumes de investimentos ou composição de conselhos. Assume-se, neste estudo, o fato de que pesquisadores não possuem a prerrogativa de designar, aleatoriamente em relação a tais variáveis observáveis ou não, os sujeitos da pesquisa a um dos dois grupos considerados. Considerando a influência de variáveis não observáveis ou de dados não disponíveis, esta limitação pode enfraquecer o desenho da pesquisa ao selecionar, para um dos grupos analisados, indivíduos cujas características, observadas ou não, estão correlacionadas com os os valores potenciais da variável resposta.

Um bom experimento natural é definido como aquele que possui uma fonte clara e exógena ${ }^{4}$ de variação das variáveis explicativas, fonte esta que determina a ocorrência do tratamento (Meyer, 1995). Em geral, alterações em políticas ou leis constituem bons experimentos naturais (Bertrand, Duflo, \& Mullainathan, 2004). Estas segregam grupos sobre os quais a mudança deveria exercer efeitos e grupos em que a mudança não deveria exercer efeitos, constituindo, portanto, uma fonte de variação exógena oriunda da variável que distingue um grupo do outro, na busca por condições análogas àquelas do experimento ideal.

No caso da presente investigação, a lei, elemento que constitui a alteração exógena, diferencia os grupos de maneira semelhante à realizada em experimentos ideais, se fosse admissível a aleatoriedade do estabelecimento das regras constantes na lei. Esta lei, conforme o texto original, emprega o critério da existência de empréstimos com partes relacionadas estrangeiras. No entanto, dado que o pesquisador não possui a prerrogativa de intervir na forma como os grupos são determinados e que políticas normalmente possuem um objetivo bem

\footnotetext{
${ }^{4}$ Um elemento é dito exógeno a um sistema quando é determinado fora dele. Por exemplo, o evento em estudo não depende das características das empresas da amostra. No entanto, se fosse possível comprovar que a lei foi elaborada a partir de estudos prévios relacionados às variáveis empregadas nesta investigação, o mesmo não seria válido.
} 
definido e um grupo sobre o qual atuar, surge o questionamento acerca da existência de correlação entre o tratamento e quaisquer outros elementos da população. Por exemplo, empresas maiores estariam mais propensas ao tratamento? Espera-se que experimentos naturais, leis em especial, designem os grupos de tratamento e controle de forma tão independente quanto se aleatória fosse, mas não existem garantias de que isso ocorre. $\mathrm{O}$ desenho da pesquisa deve considerar este aspecto e prover mecanismos que permitam a identificação do efeito investigado mesmo quando a designação dos sujeitos aos grupos não é aleatória. Especificamente, neste estudo o desafio metodológico consiste de empregar um método que observe características individuais dos sujeitos de forma que permita a identificação do efeito da lei sobre as práticas de financiamento das organizações que compõem o grupo tratamento, ou seja, controlar a variação de características observadas e não observáveis para que se possa mensurar o resultado da combinação entre o elemento "partes vinculadas estrangeiras" e o advento da lei sobre o financiamento das operações da organização, sem que se confunda o efeito de, por exemplo, ser uma "grande empresa" ou "agressividade em planejamento tributário" com o efeito do tratamento.

Da mesma forma, a definição do tratamento requer elaboração cuidadosa, dado o contexto. Consistiria, o grupo tratamento, apenas daquelas firmas cujos índices de endividamento encontram-se acima dos valores estabelecidos pela lei ou também daquelas que possuem valores inferiores? Em seu estudo, Büettner et al (2012) determinaram como "tratadas" as firmas com endividamento acima do valor estabelecido em norma, enquanto que Wamser (2014) adota como tratadas as empresas que possuem índices de empréstimos intercompanhia próximos a valores críticos estabelecidos em lei. No entanto, como visto na seção teórica deste texto, o advento de normas dessa natureza pode, além de causar seus efeitos esperados, incentivar a contratação de empréstimos intercompanhia, dado que formaliza um limite para essas operações, bem como o fato de ter endividamento excessivo pode ser uma característica da estratégia da empresa, não necessariamente se correlacionando com setor de atuação ou qualquer outro elemento observável em demonstrações financeiras. Nestas condições, seria plausível observar que não somente firmas cujos EIC encontram-se acima do safe haven ratio modificariam seu endividamento, mas também aquelas que se encontram abaixo do índice previsto na lei poderiam tomar empréstimos até o limite, aproveitando-se, seguramente, da norma e obtendo o benefício tributário do endividamento intercompanhia. Ainda, podem existir empresas que não tomariam qualquer decisão em função da norma, o que constitui um fenômeno de difícil investigação empírica. Uma análise descritiva dos dados 
deverá evidenciar preliminarmente o comportamento das empresas analisadas. Dado o exposto, considerando que o simples fato de poder contar com uma parte relacionada ${ }^{5}$ fora do país confere à empresa a prerrogativa de adotar o endividamento intercompanhia como prática de planejamento tributário, o grupo tratamento será composto por empresas brasileiras que divulgam demonstrações financeiras no Brasil e possuem partes vinculadas em outros países. Estas firmas possuem vínculos diretos ou indiretos com outras entidades que poderiam oferecer condições diferenciadas na cessão de recursos financeiros, o que as coloca em posição de enquadramento em pelo menos um dos artigos da lei. Defende-se que este "tratamento" consiste de prerrogativa obtida pela empresa em tempo suficientemente anterior ao advento da lei e, portanto, em conformidade com a estratégia de identificação adotada, atende aos requisitos necessários para que se possa identificar a relação entre os fenômenos avaliados, especialmente o fato de que, quando aplicável, a decisão pelo estabelecimento da parte relacionada estrangeira não possui, a priori, correlação com a existência da lei nem com seus termos. Nos casos em que não se trata de decisão discricionária, assume-se que a existência de parte vinculada no exterior se deve à atuação das forças de mercado. Ainda, é legítimo argumentar que a lei foi instituída em função da existência de empresas como essas, no intuito de coibir práticas agressivas de planejamento tributário. No entanto, não por isso se deve esperar poder concluir, a partir de correlação significante entre características dessas empresas e o fato de elas pertecerem ao grupo tratamento, que alterações observadas na variável dependente das empresas deste grupo se dão como efeito causal da lei em questão. Outras políticas não observadas podem afetar esta variável em ambos os grupos, mas o método de identificação empregado permite que os grupos sejam distintos, além de estabelecer a premissa de que suas respostas a outras políticas que não a analisada neste modelo são semelhantes. Mais especificamente, a diferença esperada entre os valores obtidos da variável resposta antes e após a intervenção, seja qual for o método de estimação, deve ser a mesma nos dois grupos caso o evento não ocorresse.

Nos casos em que empresas incorrem em despesas consideradas não dedutíveis em função da norma de subcapitalização, não havendo alteração da estrutura de capital da firma, se poderia concluir pela necessidade dos recursos existentes na forma de EIC para fins de financiamento

\footnotetext{
5 Para os fins que interessam a este estudo, partes vinculadas são definidas como "pessoas vinculadas" na Lei 9.430/96: matrizes, filiais, sucursais, coligadas, controladas, controladoras e pessoas jurídicas que, simultaneamente à empresa brasileira, possuem pelo menos $10 \%$ de seu Patrimônio Líquido em posse de uma mesma pessoa. Em todos os casos, a pessoa vinculada deve ser residente ou domiciliada no exterior. Outros casos se aplicam, mas não a este estudo.
} 
operacional. No entanto, se essa necessidade constitui matéria de planejamento tributário e, ainda assim, não se observa alteração na estrutura de capital, torna-se necessária a realização de análise comparativa de casos, pois o efeito observado, ou seja, a manutenção da estrutura de capital, não terá suas causas identificadas por meio do modelo econométrico ora proposto. Todavia, identificar as razões pelas quais determinadas companhias optam por arcar com custos adicionais de manter empréstimos intercompanhia após o advento da lei, mantendo a condição de subcapitalização, não constitui parte da proposta deste estudo.

Por outro lado, se houver alteração da estrutura de capital como efeito da lei, dois cenários são possíveis: redução ou aumento. A redução implicaria possível eliminação ou redução dos EIC e, por conseguinte, a constatação de que a manutenção destes recursos na empresa não compensa a perda do benefício tributário. $\mathrm{O}$ aumento poderia resultar do fato de que a firma não atingira ainda o safe haven ratio e, portanto, faz uso de sua prerrogativa de obter benefícios tributários com maior endividamento. Por outro lado, a dívida pode ter sido aumentada por meio da contratação de empréstimos externos, sugerindo a possibilidade de existirem outras explicações para a elevação da alavancagem, inclusive a existência de elementos estratégicos na gestão do endividamento. A impossibilidade de identificar se uma redução ou aumento da dívida se deve a alterações nos empréstimos intercompanhia constitui uma limitação do estudo, o qual visa tão somente à investigação que concerne a alterações da proporção do Ativo Total que é financiada por dívida.

\section{Dados}

Para desenvolver o trabalho proposto, os dados foram obtidos inicialmente das demonstrações financeiras das empresas constantes na lista "As 10 Maiores Estrangeiras" da Especial Exame Melhores e Maiores 2014 (Exame, 2014, p. 495). Esta lista possui 144 empresas estrangeiras de quinze países, as quais compõem a fonte original de dados do grupo tratamento neste estudo. Os dados do grupo controle foram coletados de uma amostra de empresas emissoras de títulos na bolsa de valores brasileira B3. Devido à indisponibilidade de dados ou à impossibilidade de obtê-los, a lista da revista Exame proveu efetivamente uma amostra de 77 empresas estrangeiras. Uma amostra adicional de companhias foi obtida na base de dados Economatica ${ }^{\circledR}$ e, em seguida, o grupo de companhias estrangeiras foi complementado por meio de análise de informações disponíveis no site da CVM, possibilitando a identificação 
de empresas que, embora não tivessem origem estrangeira, possuíssem partes relacionadas fora do Brasil. Estes dados foram obtidos a partir dos relatórios enviados à entidade pelas próprias companhias. Ao final do ajuste de dados, o grupo de empresas com parte vinculada no exterior, grupo "tratamento", conta com 168 companhias. Portanto, este grupo é composto tanto por empresas de origem estrangeira quanto por empresas brasileiras que também possuem partes relacionadas no exterior.

O grupo "controle" é composto por empresas sem partes relacionadas estrangeiras, cujos dados podem ser obtidos no banco de dados Economatica ${ }^{\circledR}$. Dentre todas as empresas domésticas disponíveis nesta base de dados, foram selecionadas aquelas que possuíam ações ordinárias ou preferenciais ou títulos privados de dívida negociados no ano em questão. Para fins de certificação de que não existe capital estrangeiro no patrimônio destas entidades, as empresas deste grupo doméstico tiveram seus Formulários de Referência anuais avaliados por meio de consulta ao site da Comissão de Valores Mobiliários (CVM). Aquelas empresas que reportaram a existência de parte relacionada estrangeira receberam, naquele ano, a designação para o grupo tratamento. Vale ressaltar que, no que se refere ao período entre 2006 a 2008, o documento avaliado foi o IAN (Informações Anuais), também disponível no mesmo site. $\mathrm{O}$ período de coleta de dados compreendeu exercícios de 2006 a 2014 e resultou, preliminarmente, em 2.070 observações de 101 empresas do grupo controle e 167 no grupo tratamento. No entanto, após ajuste de dados descrito a seguir para retirada de observações com Patrimônio Líquido negativo, foi obtido um painel não balanceado com 252 companhias e 1.816 observações. Destas, sendo 605 de 84 empresas do grupo controle e 1.211 de 168 empresas do grupo de tratamento, das quais 955 ocorreram antes e 861 após o início da vigência da lei. A extração de um painel balanceado destes dados, que consiste de empresas que possuem observações em todos os períodos e não alteram a condição de possuir (ou não) parte vinculada estrangeira, resulta em uma subamostra que contém 114 empresas e 1.026 observações, pertencentes a 70 empresas do grupo tratamento, com 630 observações, e 44 do grupo controle, com 396 observações.

\section{Descrição das variáveis}

Os dados foram obtidos por meio de coleta manual e consulta a base de dados privada, sendo, as Demonstrações Financeiras anuais publicadas pelas companhias em jornais de grande 
circulação, a fonte da coleta manual. A unidade padrão dos dados é o milhar de reais na data da publicação e os valores se referem ao ano da observação. As variáveis empregadas neste estudo foram as seguintes:

- Ativo Total da companhia;

- Ativo Imobilizado dividido por Ativo Total da companhia;

- Lucro Bruto dividido por Ativo Total da companhia;

- Vendas Líquidas dividas por Ativo Total da companhia;

- Dívida onerosa total, de curto ou longo prazo;

- Patrimônio Líquido da companhia;

- Variável dummy que indica se a observação ocorreu antes de $2011(=0)$ ou após este ano $(=1)$;

- Variável dummy que indica se a empresa a que pertece determinada observação possui partes vinculadas no exterior.

\section{Estratégia de Identificação}

Conforme mencionado nas seções anteriores, o interesse dessa investigação é entender se empresas que possuem partes vinculadas estrangeiras apresentaram variação diferente daquela observada nas empresas que não as possuem, no que tange à parcela de seus ativos que é financiada por dívida, como resultado da emissão de normas de subcapitalização. Estas normas efetivamente reduzem o tax shield provido por empréstimos intercompanhia que excedem os limites estabelecidos na lei.

Considerando recentes constatações acerca da substituição de EIC por financiamento externo na presença de regras de subcapitalização (Büettner et al., 2012; Wamser, 2014), a estratégia de identificação do efeito da vigência de normas para a subcapitalização no Brasil fundamenta-se na existência de diferenças entre as variações da estrutura de capital das empresas do grupo "tratamento" em comparação com outro grupo de empresas que possa representar seu contrafactual, posto que a substituição de recursos internos por externos pode ocorrer de forma imperfeita. Este estudo está fundamentado na premissa de que, se a lei que restringe a dedução de juros para cálculo de tributos sobre o lucro restringe a dedução desses pagamentos somente quando referentes aos EIC com partes relacionadas no exterior, então, se estes valores se enquadrarem acima dos limites estabelecidos pela legislação, empresas nessa condição substituirão seus EIC por financiamento externo quando estes forem relevantes para o funcionamento da companhia e precisarem ser mantidos (Wamser, 2014). Portanto, mantidas constantes outras variáveis, uma alteração relativa da razão entre dívida total e Ativo Total no 
grupo "tratamento" após o estabelecimento da norma pode ser efeito da norma e, tanto a manutenção do grau de alavancagem quanto sua elevação ou redução, podem ser explicados tendo como causa provável um conjunto de elementos, dentre os quais inclui-se o advento da lei. No entanto, atribuir este efeito à lei em questão depende da adequação do método empregado e da natureza dos dados, que devem atender a determinadas premissas constitutivas.

Entende-se que o estimador de diferenças em diferenças (DD) constitui uma forma potencialmente adequada de se estimar o efeito causal investigado, especialmente em pesquisas que apresentam, como principal desafio, o fato de que indivíduos ou grupos submetidos ao tratamento podem ser diferentes daqueles inseridos no grupo de controle. O DD consiste em identificar uma intervenção ou tratamento e subsequente comparação da variação temporal da variável resposta nos dois grupos (Bertrand et al., 2004). Neste caso, o interesse reside em estimar a diferença entre as alterações na razão entre dívida e Ativo Total das empresas dos dois grupos antes e após o início da vigência da lei.

Overesch e Wamser (2006) adotaram, no intuito de entender se a política de financiamento intercompanhia é determinada pela regra tributária vigente, estratégia semelhante ao investigar a influência das regras de subcapitalização em dois momentos da legislação alemã sobre a estrutura de capital de multinacionais instaladas naquele país. No entanto, como diferenças em relação à estratégia adotada neste projeto, o modelo adotado por Overesch e Wamser (2006) inclui, como variável explicativa, efeitos fixos de empresa e a diferença entre as alíquotas legais de tributos sobre a renda na Alemanha e no país de origem de cada uma das subsidiárias. Ainda, estes autores mantêm apenas observações de empresas que possuem algum valor de empréstimos intercompanhia em suas demonstrações financeiras, excluindo de seus dados as subsidiárias que não os possuem. Esta característica do estudo pode eliminar importantes fontes de variação na propensão que empresas possuem para obter dívida externa ou para não obter dívida intercompanhia.

O estimador DD tem sido recorrentemente usado no estudo dos efeitos do estabelecimento de novas políticas ou modificação de políticas já existentes e, tecnicamente, consiste em uma abordagem que frequentemente usa dados em painel (pooled cross sections) com interações apropriadas entre as variáveis de tratamento e tempo. Conforme Wooldridge (2010, p. 148), o estimador DD pode ser fundamentalmente definido como:

$$
\hat{\delta}=\left(\hat{y}_{B, 2}-\hat{y}_{B, 1}\right)-\left(\hat{y}_{A, 2}-\hat{y}_{A, 1}\right)
$$


Em que $\delta=$ estimador DD, $y_{B, z}=$ valor médio de $y$ (variável resposta) do grupo tratamento antes $(\mathrm{z}=1)$ ou após $(\mathrm{z}=2)$ o tratamento e $y_{A, z}=$ valor médio de $y$ do grupo controle antes ou após o tratamento.

No modelo econométrico constante na Equação 1, o estimador DD é calculado por meio da estimação do coeficiente da interação entre a dummy de grupo tratamento e a dummy de período. Esta interação será diferente de zero somente quando a observação pertencer ao período pós-intervenção e a empresa for do grupo "tratamento". No modelo ilustrado pela Equação 1, $t_{i t}$, dummy que indica se a observação ocorreu antes ou depois do início da vigência da lei, captura fatores que causariam mudanças na variável dependente mesmo que a intervenção não ocorresse (Wooldridge, 2010, p. 148) e, portanto, inclui efeitos de políticas não observadas. $\mathrm{O}$ termo que identifica a existência de partes vinculadas estrangeiras, $p v_{i}$, captura diferenças entre os grupos tratamento e controle antes da intervenção. Por fim, a interação entre estas duas variáveis captura a diferença média entre os grupos de tratamento e controle antes e após a intervenção, que é o que se busca identificar.

$$
y_{i t}=\beta_{0}+\beta_{1} t_{i t}+\beta_{2} p v_{i t}+\beta_{3} p v_{i t} * t_{i t}+\beta_{4} X^{\prime}+\varepsilon_{i t} \quad \text { Equação } 1
$$

Em que:

$y_{i t}$ : variável resposta de interesse, a razão entre dívida total e ativos totais;

$\beta_{0}$ : efeito parcial sobre a variável resposta das empresas sem partes vinculadas estrangeiras antes da vigência da lei;

$t_{i t}$ : variável dummy que indica se a observação é de antes ou após a lei. $\beta_{1}$ consiste do efeito parcial sobre as empresas sem partes vinculadas estrangeiras após o evento da lei;

$p v_{i t}$ : variável dummy que indica se a observação pertence à empresa $i$ que possui parte vinculada no ano $t$ ou não. $\beta_{2}$ consiste do efeito parcial sobre a estrutura de capital dessas empresas antes do advento da lei;

$\beta_{3}$ : estimador de diferenças-em-diferenças. $\beta_{3}$ consiste do efeito parcial, após a vigência da lei, sobre a variável dependente das empresas que possuem parte vinculada estrangeira;

$X^{\prime}$ : vetor das variáveis de controle;

$\varepsilon_{i t}:$ resíduo aleatório;

O modelo representado na Equação 1 foi estimado para identificar a diferença de resposta nas políticas de financiamento dos dois grupos em questão. Alternativamente, são estimados modelos que incluem efeitos fixos de ano e de empresa e regressões utilizando pareamente dos dados com propensity score matching. 
Variáveis de controle, empregadas na estimação de efeitos deste estudo, incluem elementos apresentados pela literatura relacionada como determinantes da estrutura de financiamento de empresas, tais como tangibilidade de ativos, lucratividade (Myers \& Majluf, 1984; Rajan \& Zingales, 1995; Scott, 1977), tamanho (Harris \& Raviv, 1991), e vendas (Forte, Barros, \& Nakamura, 2013; Overesch \& Wamser, 2010a; Pfaffermayr, Stöckl, \& Winner, 2013; Titman \& Wessels, 1988). Evidências empíricas apontam para correlação positiva entre a variável dependente deste estudo e parcela fixa do Ativo Total, enquanto que há dissonâncias no que tange ao sinal da correlação entre as variáveis tamanho e lucratividade e a estrutura de financiamento das empresas. Se, por um lado, empresas maiores apresentam menor risco de falência, dado que apresentam melhores condições e garantias para a obtenção de crédito, por outro lado, essas mesmas empresas, em função de serem maiores, atraem mais investidores propensos a adquirir títulos de seu Capital Social. Por sua vez, a lucratividade pode ter correlação positiva ou negativa com a variação da parcela dos ativos que é financiada por dívidas. Conforme mencionado na seção teórica, a distribuição de lucros por meio de caixa e subsequente contratação de dívidas constitui uma forma de manter maior controle sobre as ações dos administradores da empresa. Ao mesmo tempo, as empresas, em tese, prefeririam financiar suas operações com recursos próprios oriundos de suas atividades operacionais. Portanto, não se poderia prever a direção da correlação entre estas duas últimas variáveis e o endividamento das empresas dessa amostra (Rajan \& Zingales, 1995). Neste contexto, as variáveis de controle são definidas como se segue conforme Tabela 2, considerando que a variável lucratividade busca mensurar eficiência operacional antes das deduções que decorrem de planejamento tributário e, por isso, teve sua definição adaptada daquela verificada na literatura mencionada.

A estimação do efeito causal por meio do estimador de DD parte do pressuposto de que alterações na variável resposta seriam as mesmas em ambos os grupos se a intervenção não ocorresse. Conforme suposições do método em relação aos dados, os grupos comparados podem ser distintos, mas, para serem comparáveis, a variável de resposta deve ter tendências semelhantes em ambos os grupos antes do evento. Neste caso, supõe-se que a variação da parcela dos ativos que é financiada por dívidas nas empresas que possuem partes vinculadas estrangeiras seria a mesma, em termos relativos, que aquela observada no grupo de empresas que não possuem partes vinculadas no exterior, não tivesse, a lei, sido promulgada. $\mathrm{O}$ grupo 
controle, portanto, representa um contrafactual ${ }^{6}$ do grupo tratado caso este não fosse submetido aos efeitos da lei, sendo possível assumir, em face do método, que a alocação das unidades observacionais designadas aos grupos tratamento e controle produz condições que permitem estimar o efeito da lei como se esta aleatória fosse, na definição de Rubin (1974).

Tabela 2 - Variáveis de controle empregadas no estudo.

\begin{tabular}{lll}
\multicolumn{1}{c}{ Controle } & \multicolumn{1}{c}{ Definição } & \multicolumn{1}{c}{ Fonte } \\
\hline Tangibilidade & $\begin{array}{l}\text { Razão entre ativos fixos e Ativo } \\
\text { Total }\end{array}$ & $\begin{array}{l}\text { Myers \& Majluf (1984); Rajan \& } \\
\text { Zingales (1995); Scott (1977) }\end{array}$ \\
Tamanho & $\begin{array}{l}\text { Razão entre Vendas Líquidas e } \\
\text { Ativo Total }\end{array}$ & Harris \& Raviv (1991) \\
& $\begin{array}{l}\text { Razão entre Lucro Bruto e } \\
\text { Vendas Líquidas. Adaptado para }\end{array}$ & $\begin{array}{l}\text { Overesch \& Wamser, (2010a); } \\
\text { Pfaffermayr, Stöckl, \& Winner } \\
\text { (2013); Titman \& Wessels (1988); }\end{array}$ \\
& $\begin{array}{l}\text { Myerletir eficiência operacional. } \\
\text { Lucratividade }\end{array}$ & $\begin{array}{l}\text { Zingales (1995); Scott (1977) } \\
\text { Razão entre dívida e capital total }\end{array}$ \\
& $\begin{array}{l}\text { Rajan \& Zingales (1995) } \\
\text { disponível }\end{array}$ & \\
Endividamento & &
\end{tabular}

Fonte: autor.

O efeito esperado da diferença entre receber o tratamento e não recebê-lo $(Y(1)$ e $Y(0))$, condicional a características observadas e não observadas, deve ser a mesma para os dois grupos. O fato de que essa diferença permanece imutável antes e depois da intervenção $(t=0$ e $t=1)$ consiste da Hipótese Nula deste estudo:

$H_{0}$ : a diferença relativa de endividamento entre os grupos de tratamento e controle não se modificou após o início da vigência da lei.

A impossibilidade de se observarem resultados da não intervenção no grupo tratamento após o evento, o que torna impossível testar de forma perfeita o efeito do tratamento, não torna

\footnotetext{
${ }^{6}$ Contrário aos fatos; representa o grupo tratamento sob a condição de que o fato intervenção não tenha ocorrido.
} 
impossível a produção de conhecimentos relevantes acerca do fenômeno em questão. Esta situação, convenciona-se descrever como "o problema fundamental da inferência causal" (Basu \& Rubin, 1980; Holland, 1986; Rubin, 1974). Seleção adequada do grupo controle e eventual ajuste do modelo econométrico por meio de adição de controles torna plausível a aceitação da premissa da comparabilidade entre os grupos (Stuart, Duckworth, Simmons, \& Barry, 2014). Estudos desta natureza, que envolvem a comparação de sujeitos distintos, assumem a premissa descrita por Holland (1986) como "homogeneidade das unidades", em uma aproximação ao modelo ideal de experimentos. Embora não se possa provar, de forma generalizada, essa homogeneidade, a "preparação" do grupo controle de forma a torná-lo tão semelhante quanto possível ao grupo tratamento possibilita a aproximação de um contrafactual do tratamento a que se submete o grupo das empresas que possuem partes vinculadas estrangeiras, permitindo a estimação dos efeitos da intervenção por meio do cálculo da diferença entre os dados observados.

No contexto da pressuposição de homogeneidade das unidades, quando a designação de cada sujeito de uma amostra a um dos grupos é aleatória considera-se plausível que esta alocação seja independente dos resultados potenciais da variável dependente, tal qual nos experimentos ditos ideais, bem como de quaisquer outras variáveis (Holland, 1986). O resultado da obtenção desta independência é o fato de que o efeito esperado do tratamento é igual ao efeito esperado do tratamento no grupo tratamento: $E\left(Y_{t}\right)=E\left(Y_{t} \mid S=t\right)$. Da mesma forma, o valor esperado do não tratamento é igual ao valor esperado do não tratamento no grupo controle: $E\left(Y_{c}\right)=E\left(Y_{c} \mid S=c\right)$, em que Yt e Yc representam, respectivamente, o efeito do tratamento no grupo de tratamento e no grupo de controle, $\mathrm{S}$ é a designação a um dos grupos, $t$ é pertencimento ao grupo de tratamento e $c$ é pertencimento ao grupo controle. O efeito médio do tratamento $T$ pode ser, então, obtido por meio de dados observados ao satisfazer-se a equação:

$$
T=E\left(Y_{t} \mid S=t\right)-E\left(Y_{c} \mid S=c\right) \quad \text { Equação } 2
$$

A comparabilidade entre os grupos, premissa do método de estimação empregado neste estudo, é uma consequência direta da independência do tratamento, condição facilmente obtida em estudos controlados, em que o desenho da pesquisa prevê que os sujeitos sejam designados aleatoriamente aos grupos. No caso deste estudo, a condição de pertencer ao grupo tratamento resulta de elementos que estão fora do controle do desenho da pesquisa. Em situações em que não é possível garantir a independência da designação dos sujeitos aos grupos, o efeito estimado na Equação 2 configura uma medida de associação, não representando o efeito real do 
tratamento (Holland, 1986). Para serem ditos comparáveis, os grupos devem apresentar tendências tão semelhantes quanto possível no que tange à oscilação da variável dependente antes do evento. É possível realizar verificações gráficas e cálculo de estatísticas desta semelhança, argumentos apresentados na seção de análise dos dados. Dado que não se observam os efeitos de não submeter o grupo tratamento à intervenção em análise, busca-se demonstrar que, sendo os grupos comparáveis, o efeito do não tratamento do grupo controle após o momento da intervenção consiste do efeito que se observaria no grupo tratamento, não tivesse, este, sido submetido à intervenção.

Ao comparar o estimador DD a outros estimadores, Wooldridge (2011, p. 148) aponta algumas das vantagens em se usar esta estratégia de identificação de efeitos causais. Ao avaliar somente a variável resposta no grupo tratamento, ignorando o grupo controle, por exemplo, efeitos de outras políticas (confounding policies) ou outros fatores observados ou não, tais como IFRS $^{7}$ e câmbio, poderiam enviesar o estimador, dado que a variável resposta pode variar como função de outros elementos. Ao empregar um grupo controle, que não está sujeito à intervenção, o estimador DD considera que outros elementos afetam igualmente ambos os grupos e, controlando estes efeitos, identifica apenas o efeito da política em questão. Assume-se, portanto, que quaisquer outras políticas ou variações sistemáticas da variável resposta são sentidas com a mesma intensidade em ambos os grupos, o que é verificado no teste do paralelismo das tendências. Outra alternativa de estimação de efeitos de tratamentos seria ignorar o período anterior à intervenção, calculando a diferença da média da variável resposta dos dois grupos apenas após o tratamento e atribuindo os efeitos à intervenção. Neste caso, se houver diferenças sistemáticas não observadas entre os grupos, e se essas diferenças não forem resultado do tratamento, atribuí-las à intervenção seria um erro. Necessário se faz verificar se essas diferenças já existiam antes da intervenção. De fato, o estimador DD considera efeitos específicos tanto de tempo quanto de grupo, eliminando os problemas mencionados (Wooldridge, 2011, p. 148), sendo um de seus benefícios o potencial de evitar problemas de endogeneidade, quando se realizam comparações entre grupos heterogêneos (Bertrand et al., 2004), buscando, por meio do desenho do estudo, tornar a intervenção não aleatória em uma situação tão próxima quanto possível da aleatoriedade.

\footnotetext{
${ }^{7}$ Adoção dos padrões internacionais de contabilidade, International Financial Reporting Standards.
} 
Rubin (1974) defende que a comparação de unidades observacionais pareadas de acordo com suas variáveis observadas antes da intervenção, sendo, essas variáveis, reconhecidamente determinantes do elemento que se busca estimar, contribui para a correta identificação do efeito causal avaliado. Neste contexto, o emprego do propensity score matching (PSM) pode reduzir o viés de seleção, conforme definido por Angrist e Pischke (2009, p. 22), substitui a premissa da independência da intervenção por premissas condicionais mais fracas (Holland, 1986) e, por conseguinte, mitiga as fragilidades existentes em estudos observacionais de efeitos de políticas. Este método consiste em formar pares ou grupos de sujeitos pertencentes aos dois grupos sendo comparados, de forma que esses sujeitos sejam tão similiares quanto possível, em relação a suas características observáveis antes do evento. Desta forma, o efeito do tratamento pode ser identificado por meio da observação da diferença dos valores da variável de interesse apresentada por estes sujeitos pareados, apresentando uma estimativa do efeito real do tratamento por meio da diferença constante na Equação 1. O PSM é empregado com o objetivo de eliminar vieses existentes entre os grupos controle e tratamento decorrentes de diferenças entre características observadas (Hirano, Imbiens, \& Geert, 2003; Rosenbaum \& Rubin, 1983) e o método empregado para estimação do propensity score foi o modelo logístico descrito por Cox (1970), exemplificado por Rosenbaum e Rubin (1983, p. 47) e evidenciado na Equação 3.

$$
p s=\operatorname{pr}(z=1 \mid x)=\frac{\operatorname{pr}(z=1) * \operatorname{pr}(x \mid z=1)}{\operatorname{pr}(z=1) * \operatorname{pr}(x \mid z=1)+\operatorname{pr}(z=0) * \operatorname{pr}(x \mid z=0)}
$$

Equação 3

Na Equação 3, “ $x$ " consiste do vetor das variáveis de controle, observadas a cada um dos períodos fiscais anteriores à lei, e " $z$ " consiste da designação ao grupo tratamento. Por definição, ps, ou propensity score, consiste de um número contido no intervalo compreendido entre zero e 1 e representa, dadas as covariáveis observadas, a probabilidade da empresa $i$ receber o tratamento, ou seja, de possuir partes vinculadas estrangeiras dadas as variáveis de controle observadas. Posto que o propensity score é uma medida da probabilidade de um indivíduo qualquer, pertencente a um dos dois grupos, pertencer ao grupo tratamento e que essa probabilidade é estimada a partir dos valores das variáveis observadas, então esta estatística é tão relevante quanto o são as variáveis observadas que determinam a participação de um indivíduo qualquer na condição de "tratado" (Khandker, Koolwal, \& Samad, 2010, p. 54). 
Em artigo seminal, Rosenbaum e Rubin (1983) atestam que, em estudos com aleatorização do tratamento, os dados são coletados de tal forma que todas as covariáveis possivelmente relacionadas à alocação dos sujeitos aos grupos ou que possam, de alguma forma, influenciar a variável resposta estão incluídas no modelo estimado. Ainda, descrevem que a probabilidade de um sujeito qualquer pertecer ao grupo tratamento é conhecida nos estudos com aleatorização de tratamento, enquanto que, nos estudos sem essa característica, ela não é. As interações entre estas premissas, as regras observadas na elaboração da lei em estudo e questões de autosseleção poderiam criar fragilidades nos resultados obtidos, dado que a existência de partes relacionadas estrangeiras pode ser determinada por elementos que não constam nas Demonstrações Financeiras ou são não observáveis ou não observadas neste estudo. De fato, variáveis não observadas que determinam a existência de partes relacionadas estrangeiras configuram fragilidade no uso exclusivo do PSM como estratégia de identificação, que, nestes casos, não teria seu uso recomendado, devendo-se optar por variáveis instrumentais ou diferenças-em-diferenças para identificar relações causais (Khandker et al., 2010, p. 56). Este último, conforme os mesmos autores, lida com a heterogeneidade não observada dos dados ao considerá-la constante no tempo e, portanto, consiste de interessante estratégia a ser empregada em sinergia com o PSM.

Conforme literatura relacionada (Desai et al., 2004; Futema et al., 2009; Pfaffermayr et al., 2013; Pohlmann \& Iudícibus, 2010; Wamser, 2014), o ativo total foi usado como denominador no cálculo do quociente empregado como variável dependente deste estudo, cujo numerador é a dívida onerosa total da empresa, constituída por empréstimos e financiamentos. Diferentes estudos têm empregado medidas distintas para o que se convenciona denominar, de forma geral, alavancagem. Como exemplo, Albanez, Valle e Corrar (2012) adotam conceitos tais quais o prazo de rolagem de dívidas como critério de definição de variáveis dependentes na investigação de efeitos exercidos sobre a determinação da estrutura de capital. Rajan e Zingales (1995) definem que a razão obtida entre o total de exigibilidade e o total de ativos constitui a mais ampla de todas as medidas empregadas em estudos dessa natureza, provendo a informação dos valores deixados para os acionistas em caso de liquidação. Em seu estudo, estes autores defendem que a definição desta variável dependente ocorre em sinergia com o objeto da investigação. Por exemplo, na investigação de fenômenos relacionados a conflitos de agência e dívida, uma medida relevante seria a relação entre estoque de dívida e valor de mercado, enquanto que em estudos cujos contextos envolvem transferência de controle para 
portadores de títulos de dívida quando empresas se encontram em situação de estresse financeiro, uma medida relevante seria a razão de cobertura de juros.

Neste estudo, adotou-se a razão entre dívida onerosa total e Ativo Total. Dado que o objetivo ora proposto consistiu de avaliar a variação da proporção de dívida empregada na atividade operacional em função de uma lei que restringe o benefício tributário relacionado a determinada fonte de recursos, usar a dívida total da empresa, inclusive aquela relacionada a atividades de crédito comercial, adicionaria, à variação observada dessa dívida, efeitos não relacionados ao fenômeno investigado. Desta forma, a definição da variável dependente atende aos critérios de prover uma medida de risco de falência e de não incluir efeitos de operações com crédito comercial (Rajan \& Zingales, 1995) e, principalmente, torna possível detectar variações no endividamento total das companhias. Portanto, a variável dependente deste estudo é composta do somatório de todas as dívidas onerosas das empresas da amostra, sejam elas de curto ou longo prazo, obtidas dentro ou fora de seus grupos econômicos. Por outro lado, esta definição pode apresentar variações correlacionadas à operação da empresa. Por exemplo, a variação em créditos comerciais a receber, embora tenha um efeito sobre a variável dependente como foi definida, não tem origem em dívida onerosa e, portanto, pode gerar distorções. De fato, contas a pagar e contas a receber podem ser influenciadas em conjunto por elementos relacionados ao setor a que a empresa pertence (Rajan \& Zingales, 1995) e, por isso, este efeitos foram adicionados ao modelo. 


\section{Seção IV - Estatísticas descritivas}

Posto que a lei em questão estabelece os limites de endividamento fundamentando seus critérios no valor da participação societária mantida pelas partes vinculadas em relação Patrimônio Líquido da empresa investida, instâncias em que esta conta contábil encontra-se negativa (abaixo de zero) merecem atenção. Em síntese, do texto da lei deduz-se que não há limite de endividamento intercompanhia para empresas que se encontram nesta situação. Se, por um lado, esta prerrogativa é razoável, uma vez que empresas em dificuldades financeiras serão penalizadas por credores que avaliam suas Demonstrações Financeiras para estabelecer condições para cessão de empréstimos (Vicentini, 2014), por outro, a condição deficitária pode estar relacionada à situação de abuso de direito, excedendo os limites pela observação do fim econômico ou social desta condição e fazendo erigirem questionamentos acerca do exercício dos direitos providos pelo ordenamento jurídico com finalidade diversa daquela para a qual existem (Moraes, 2014).

Análise de estatísticas descritivas da amostra obtida evidencia a existência de instâncias em que as companhias apresentam Patrimônio Líquido negativo, as quais totalizam 254 observações. Destas, 191 pertencem a 34 empresas o grupo controle, enquanto que as outras 63 observações com Patrimônio Líquido negativo pertencem a 20 empresas do grupo tratamento. Ainda, 150 destas observações ocorreram até o ano de 2010. Ang (2015) ressalta que a literatura contábil e financeira tem atribuído pouca atenção ao fato de que empresas apresentam valores negativos em seus Patrimônios Líquidos. Nestes casos, tais observações seriam excluídas dos estudos empíricos em função da dificuldade em interpretar os índices que essa condição gera. Essa pouca relevância atribuída ao "passivo a descoberto" se revela incoerente com o fato de que, segundo o mesmo estudo, cerca de 4\% das empresas negociadas nas principais bolsas de valores norte-americanas evidenciam valores negativos de Patrimônio Líquido.

Dificuldades financeiras e propensão a falência são condições atribuídas a empresas que apresentam valores negativos em seus patrimônios (Dichev, 1998; E. Fama \& French, 1992), sendo uma situação que, em tese, resulta de perdas cumulativas ao longo do tempo. No entanto, estudos ressaltam a persistência, por muitos anos, de empresas que, embora apresentem mais obrigações do que ativos, continuam operando (Jan \& Ou, 2012), apesar de constatações empíricas da correlação entre esta condição e situações financeiras adversas (B. Li, Lajbcygier, Guo, \& Xiaoying, 2007).

Ainda, é possível que as empresas apresentem, além de patrimônio contábil líquido negativo, obrigações em forma de dívidas (empréstimos) em somas superiores a seus ativos 
totais. Das 254 observações que mostram patrimônio negativo, 75 também apresentam ativo total menor do que o total de dívidas, ou seja, no ano do exercício contábil em que essas observações foram registradas, as companhias possuíam dívidas maiores do que todos seus bens e direitos somados. Destas, 65 (86,7\%) pertencem a empresas do grupo controle.

A legislação brasileira, na figura da Lei 9.532/97, art. $7^{\circ}$, III, permitia, até o fim do período a que os dados da amostra ora analisada pertencem, a dedução do ágio pago na aquisição de partes relacionadas para fins de apuração dos tributos sobre a renda. Valores negativos no Patrimônio Líquido de empresas no Brasil podem estar correlacionados a estratégias de planejamento tributário e fusão, cisão ou incorporação de partes relacionadas, dado que as diferenças entre valores pagos e valores justos ou contábeis resultariam em despesas futuras dedutíveis da base de cálculo dos tributos sobre a renda. Deve ser ressaltado que a legislação vigente foi alterada no ano de 2014 pela Lei 12.713 e não mais permitiu esta prática a partir do ano calendário de 2015. Casos em que esta situação foi colocada em prática já foram noticiados pela mídia nacional ${ }^{8}$. Portanto, dada a possível correlação do conteúdo informacional embutido no sinal negativo de passivos a descoberto em relação a variáveis não observáveis nas Demonstrações Financeiras, a existência de tal condição pode conferir graus relevantes de endogeneidade ao modelo empregado neste estudo, tanto na avaliação da comparabilidade entre os grupos, que ocorre por meio da verificação da correspondência entre as tendências de respostas a políticas não observadas, quanto na estimação das diferenças que são objeto do estudo.

Neste contexto, a análise de observações extremas evidencia características importantes da amostra de dados obtida. O Gráfico 1 ilustra curvas compostas por valores médios anuais, segregados por situação em que se encontra o Patrimônio Líquido na empresa na observação: se negativo ou positivo.

\footnotetext{
${ }^{8}$ Ver, por exemplo, Processo no. 12898.002308/2009-68 do Conselho Administrativo de Recursos Fiscais - CARF, que determina o pagamento dos tributos mais multa e juros referentes a amortização ágio decorrente de operação de incorporação de companhia com Patrimônio Líquido negativo. Outro exemplo a ser consultado é a Solução de Consulta no. 19, de 22 de maio de 2014 - Cosit, da Coordenação-Geral de Tributação da Receita Federal do Brasil. Em seu item 6, asserta-se que, em casos de incorporação ou fusão, ao menos uma das entidades envolvidas é extinta, ocasião em que se verte seu patrimônio à sociedade existente ou a uma nova. Em seu item 7.1, esta mesma Solução de Consulta cita o artigo 123 do Código Tributário Nacional, que veda, a convenções particulares, o poder de determinar a responsabilidade tributária dos entes envolvidos. Inexiste resposta única para casos em geral de aproveitamento de créditos tributários oriundos do acúmulo de perdas contábeis, sendo necessário se avaliar cada caso individualmente.
} 


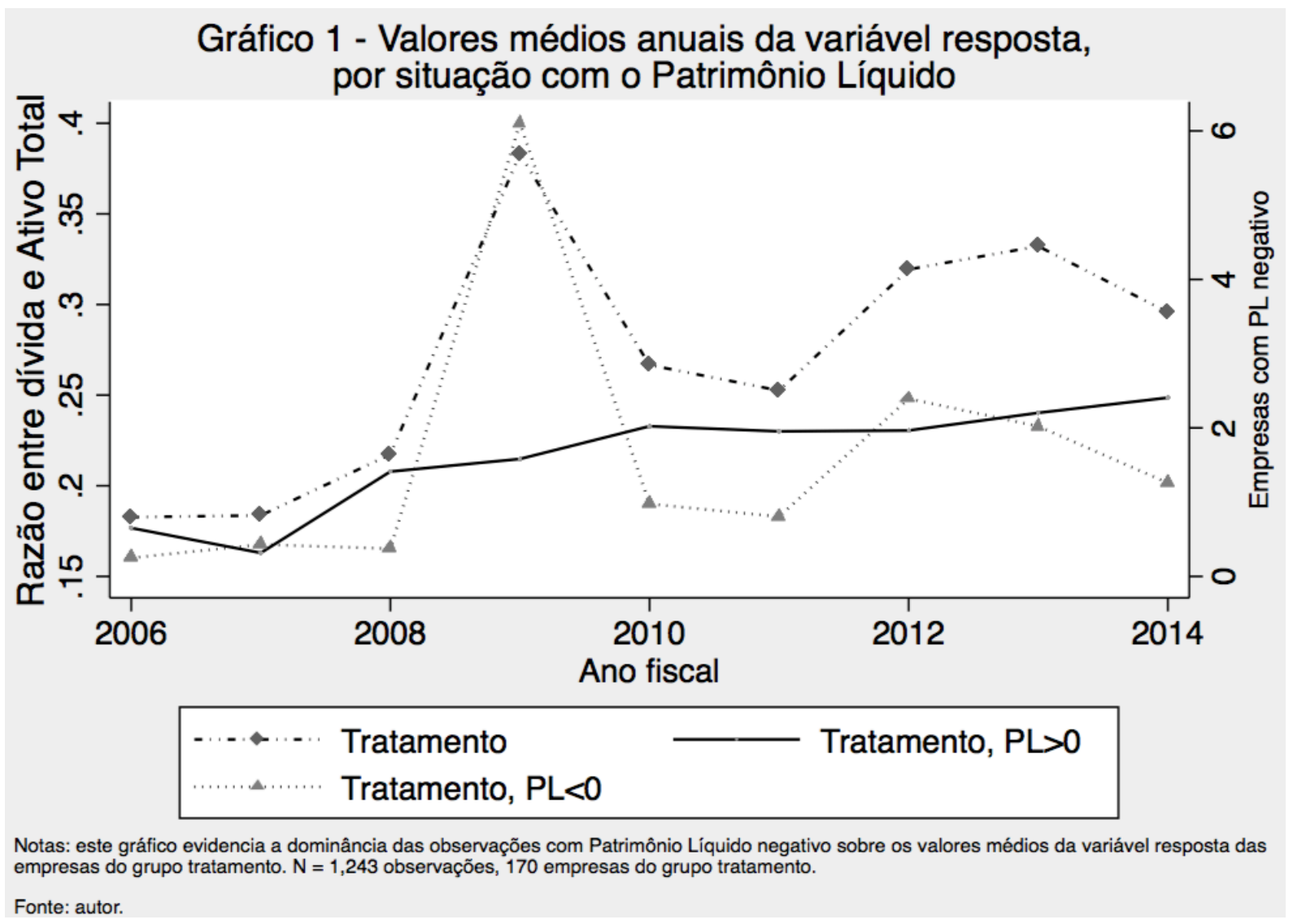

Observa-se que, uma vez extraídas as observações que contém valor negativo de Patrimônio Líquido, a curva das médias anuais da variável dependente torna-se sensivelmente alterada em relação a seu estado anterior, como pode ser verificado pela diferença entre a curva sólida e a curva tracejada. O Gráfico 2 ilusta os mesmos dados no grupo controle, possibilitando atestar o fato de que, embora os patamares da variável resposta entre os grupos sejam distintos, a semelhante influência das observações de empresas que apresentam Patrimônio Líquido negativo pode ser verificada.

Com o intuito de identificar e mensurar os efeitos de observações extremas, bem como de mitigar sua visualmente evidente influência sobre os coeficientes a serem estimados neste estudo, estatísticas específicas para cada observação foram calculadas por meio da estimação do modelo empregado neste estudo, embora não tenham sido tabuladas por razões listadas a seguir. Igualmente, foram realizadas análises gráficas de distribuição de dados observados e resíduos de estimações a fim de verificar influências que observações individuais pudessem ter sobre a estimação dos coeficientes dos modelos. 


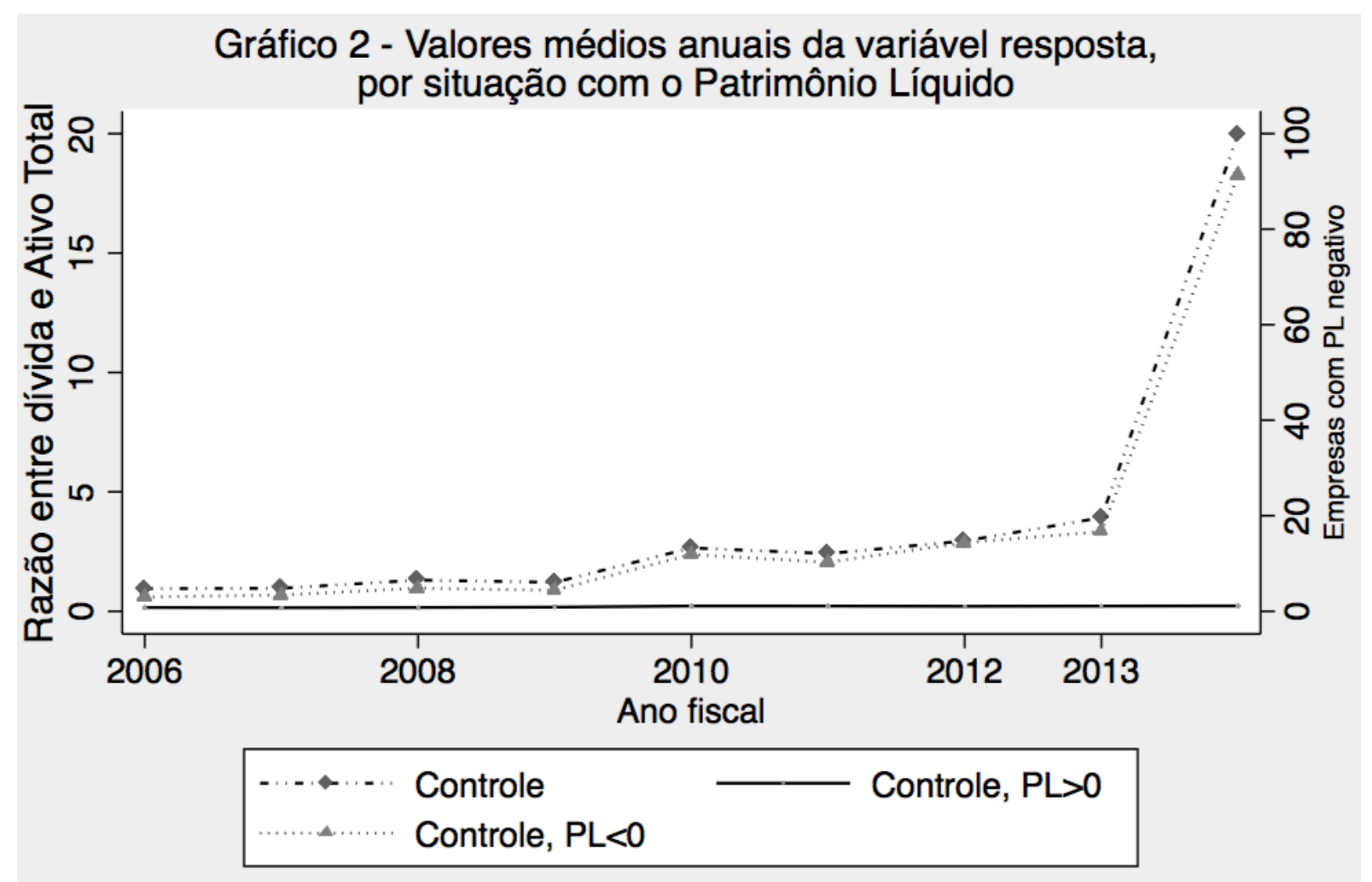

Notas: este gráfico evidencia a dominância das observações com Patrimônio Líquido negativo sobre os valores médios da variável resposta das empresas do grupo controle. $\mathrm{N}=927$ observações, 98 empresas do grupo controle.

Fonte: autor.

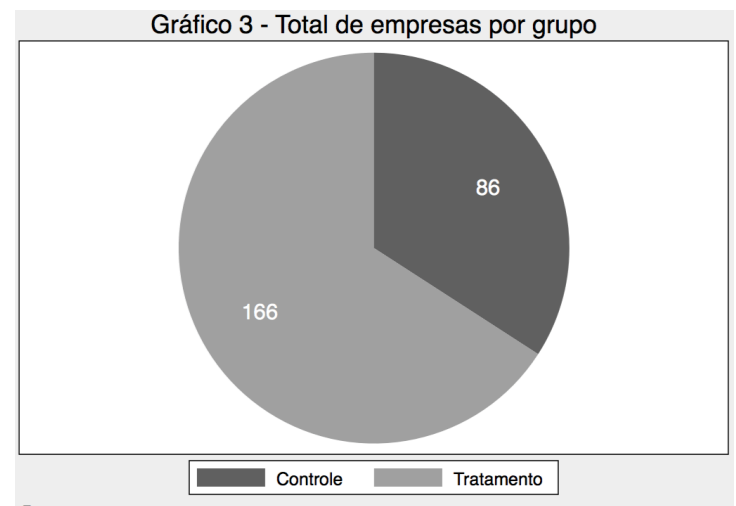

proposta, observações que apresentem

esta condição. A amostra remanescente é composta pelas quantidades de empresas e observações respectivamente descritas nos Gráficos 3 até 6. O Apêndice 1 apresenta tabelas com estatísticas descritivas segregadas entre os dois grupos e a condição de Patrimônio Líquido negativo.

Em função do aspecto particular do passivo a descoberto, o qual merece investigação individual e qualitativa que não é objeto deste estudo, bem como da visual influência que observações com Patrimônio Líquido negativo possuem sobre a distribuição temporal da variável dependente, optou-se por excluir, da análise ora

Gráfico 4 - Total de empresas por grupo e período

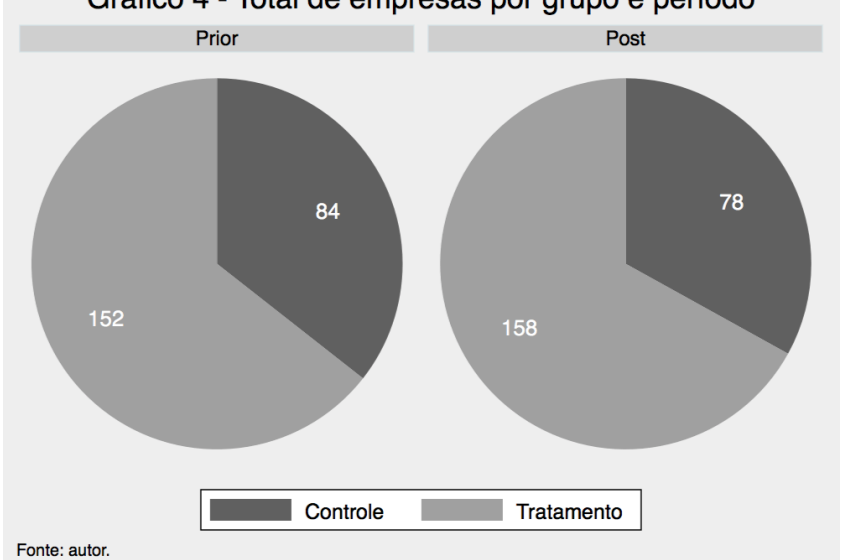


Gráfico 5 - Total de observações por grupo

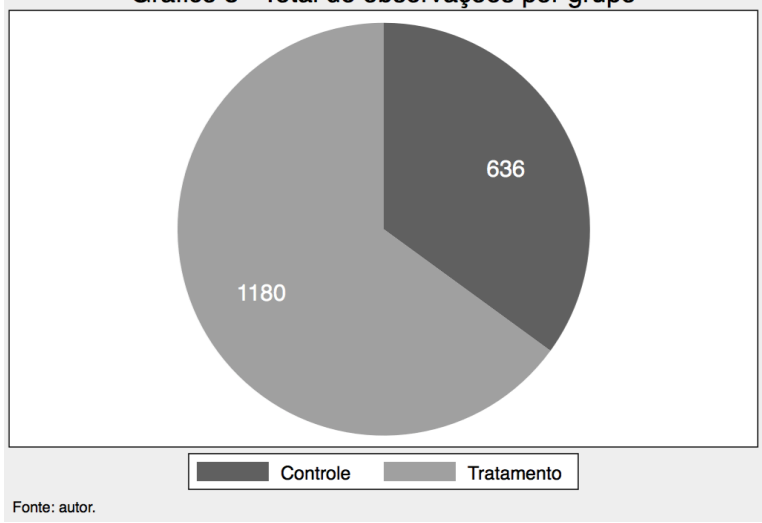

Belsley, Kuh e Welsch (1980) descrevem critérios para a identificação e classificação de observações extremas em função de sua influência sobre as estatísticas descritivas dos modelos de regressão e seus coeficientes. Observações extremas podem exercer influência sobre os coeficientes do modelo, bem como sobre os valores estimados da variável

dependente, sobre os resíduos e sobre a matriz de covariância dos coeficientes. O cálculo desta influência permite a identificação de observações que apresentam comportamento distinto daquele observado no restante da amostra. Tais estatísticas foram calculadas no contexto da amostra completa, empregando o mesmo modelo usado na análise principal deste estudo e incluindo observações com Patrimônio Líquido negativo. Os resultados desta análise corroboraram a decisão pela exclusão das observações com Patrimônio

Gráfico 6 - Total de observações por grupo e período

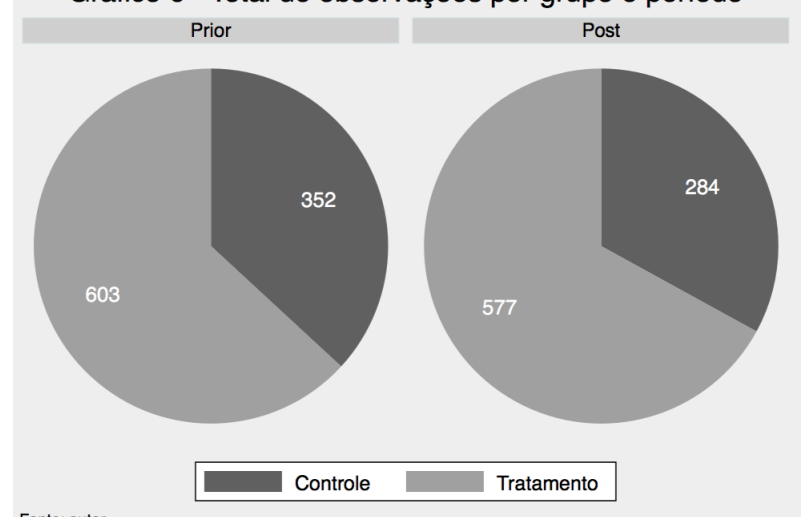
Líquido negativo, que notadamente apresentam influência sobre os coeficientes estimados por meio de mínimos quadrados ordinários. No entanto, optou-se por empregar, na análise central deste trabalho, estimador robusto no cálculo do efeito da lei e, portanto, estas quantidades não fazem sentido e não foram, portanto, tabuladas. Em seguida, para fins das análises por meio do PSM, foi empregada uma subamostra composta apenas por empresas que possuem observações durante todo o período analisado, bem como por aquelas que não mostraram alteração no que tange à existência de partes relacionadas estrangeiras. Esta amostra, de tamanho menor, compõe um painel balanceado. Portanto, este estudo empregou, para identificação do efeito de interesse, dois subconjuntos da amostra original, um deles com 1,816 observações em um painel não balanceado e, outro, com 1,026 observações.

A Tabela 3 contém estatísticas descritivas das variáveis observadas, resposta e de controle, a partir das Demonstrações Financeiras de todas as empresas com Patrimônio Líquido positivo, enquanto que a Tabela 4 apresenta coeficientes e estatísticas $t$ de testes de diferenças de médias entre os grupos para cada uma dessas variáveis anualmente. No Gráfico 7, verificase visualmente que as variações das parcelas do Ativo que são financiadas por dívidas seguem 
uma aparentemente semelhante tendência nos dois grupos, o que pode ser inicialmente corroborado pela ausência de significância das diferenças calculadas a cada ano entre os grupos, conforme observado na Tabela 4. Esta, por sua vez, evidencia o valor médio da diferença anual observada, entre os grupos, nestas razões, bem como o grau de significância dessas diferenças.

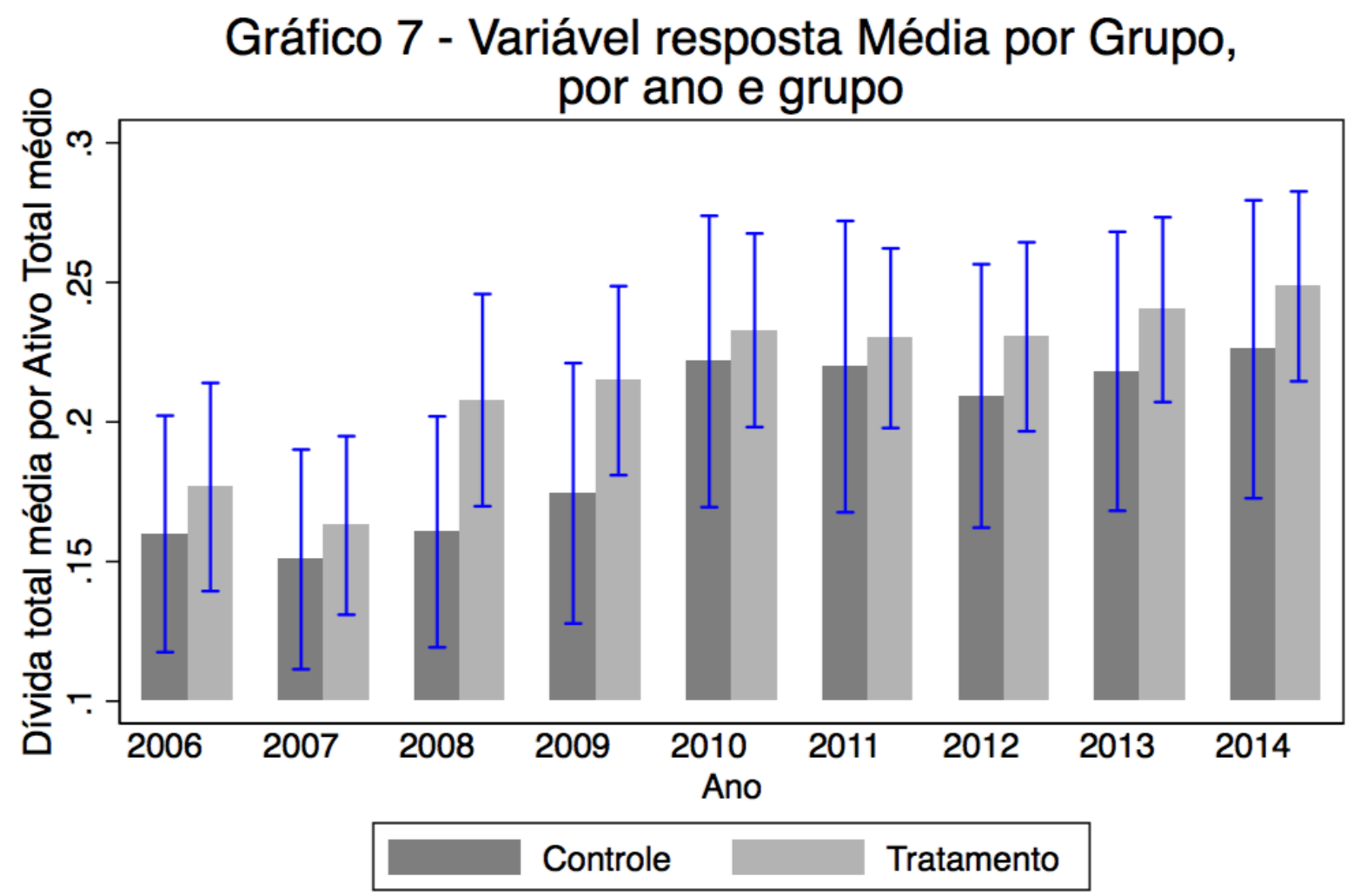

Notas: este gráfico apresenta os valores médios da variável resposta do estudo, por ano de observação. As barras representam intervalos de confiança de $95 \%$. $\mathrm{N}=1,816$ observações, 252 empresas.

No entanto, esta diferença não se mostra, em qualquer ano contido no período avaliado, significante no que se refere à variável dependente deste estudo, fornecendo, em conjunto com a análise provida no Gráfico 7, suporte à comparabilidade entre os grupos analisados e evidência no que tange ao conceito de strong ignorability de Rosenbaum e Rubin (Rosenbaum \& Rubin, 1983). O atendimento às premissas do método econométrico ora empregado encontrase formalmente representado na Seção seguinte.

A robustez da verificação do efeito do tratamento sobre as empresas tratadas foi verificada com procedimentos de propensity score matching e ponderação por propensity score em séries temporais (Linden \& Adams, 2011). Conforme Nichols (2008), a ponderação por meio dos propensity scores pode ser realizada de um número de maneiras, dentre as quais quatro são ilustradas em seu estudo e uma é empregada nesta investigação com o objetivo de 
Tabela 3 - Valores médios e medianos das variáveis observadas em ambos os grupos e a cada ano.

\begin{tabular}{cccccccccccccccccccc}
2 & 2006 & & 2007 & & 2008 & & 2009 & & 2010 & & 2011 & & 2012 & & 2013 & & 2014 \\
\hline $\mathrm{T}$ & $\mathrm{C}$ & $\mathrm{T}$ & $\mathrm{C}$ & $\mathrm{T}$ & $\mathrm{C}$ & $\mathrm{T}$ & $\mathrm{C}$ & $\mathrm{T}$ & $\mathrm{C}$ & $\mathrm{T}$ & $\mathrm{C}$ & $\mathrm{T}$ & $\mathrm{C}$ & $\mathrm{T}$ & $\mathrm{C}$ & $\mathrm{T}$ & $\mathrm{C}$ \\
\hline
\end{tabular}

Dívida Total /Ativo Total

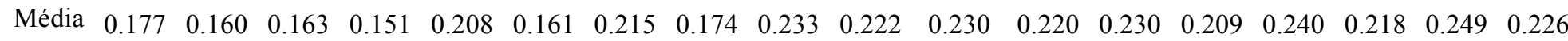

$\begin{array}{llllllllllllllllllll}\text { Mediana } & 0.147 & 0.111 & 0.152 & 0.101 & 0.175 & 0.107 & 0.160 & 0.117 & 0.181 & 0.149 & 0.201 & 0.132 & 0.196 & 0.162 & 0.228 & 0.164 & 0.238 & 0.186\end{array}$ Ativo Imobilizado / Ativo

Total

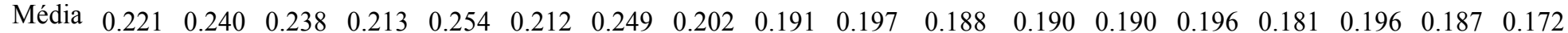

$\begin{array}{lllllllllllllllllllll}\text { Mediana } & 0.141 & 0.159 & 0.192 & 0.103 & 0.186 & 0.107 & 0.209 & 0.088 & 0.124 & 0.084 & 0.139 & 0.047 & 0.116 & 0.082 & 0.118 & 0.069 & 0.125 & 0.030\end{array}$

Vendas Líquidas / Ativo

Total

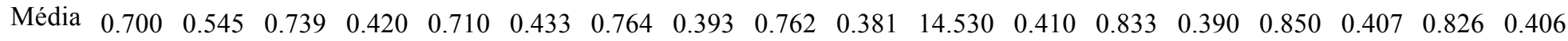

$\begin{array}{lllllllllllllllllllll}\text { Mediana } & 0.565 & 0.339 & 0.726 & 0.191 & 0.688 & 0.224 & 0.693 & 0.167 & 0.657 & 0.237 & 0.708 & 0.275 & 0.718 & 0.241 & 0.721 & 0.308 & 0.751 & 0.280\end{array}$ Lucro Bruto / Ativo Total

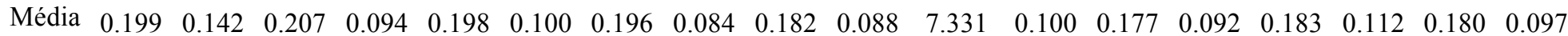

$\begin{array}{llllllllllllllllllll}\text { Mediana } & 0.124 & 0.110 & 0.159 & 0.046 & 0.141 & 0.065 & 0.130 & 0.056 & 0.162 & 0.067 & 0.142 & 0.073 & 0.149 & 0.052 & 0.155 & 0.055 & 0.151 & 0.050\end{array}$

Dívida Total / Patrimônio

Líquido

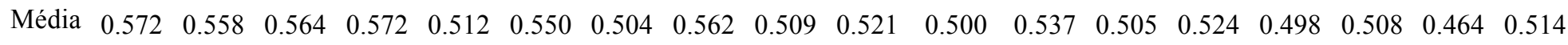
$\begin{array}{lllllllllllllllllll}\text { Mediana } & 0.593 & 0.572 & 0.580 & 0.580 & 0.480 & 0.571 & 0.465 & 0.564 & 0.468 & 0.495 & 0.452 & 0.524 & 0.464 & 0.546 & 0.443 & 0.472 & 0.418 & 0.505\end{array}$ Notas: 1,816 observações de 252 empresas. $\mathrm{T}$ = grupo tratamento; $\mathrm{C}=$ grupo controle.

Fonte: autor. 
atribuir pesos às variáveis observadas do grupo controle de forma a tornar suas distribuições semelhantes àquelas do grupo tratamento. De acordo com o mesmo autor,

"Uma regressão ponderada da variável dependente sobre o tratamento consiste portanto de uma comparação de médias entre os grupos tratamento e controle, sendo que o grupo controle é ponderado de forma a representar o resultado médio que o grupo tratamento teria exibido na ausência da intervenção" (Nichols, 2008, p. 533, tradução livre).

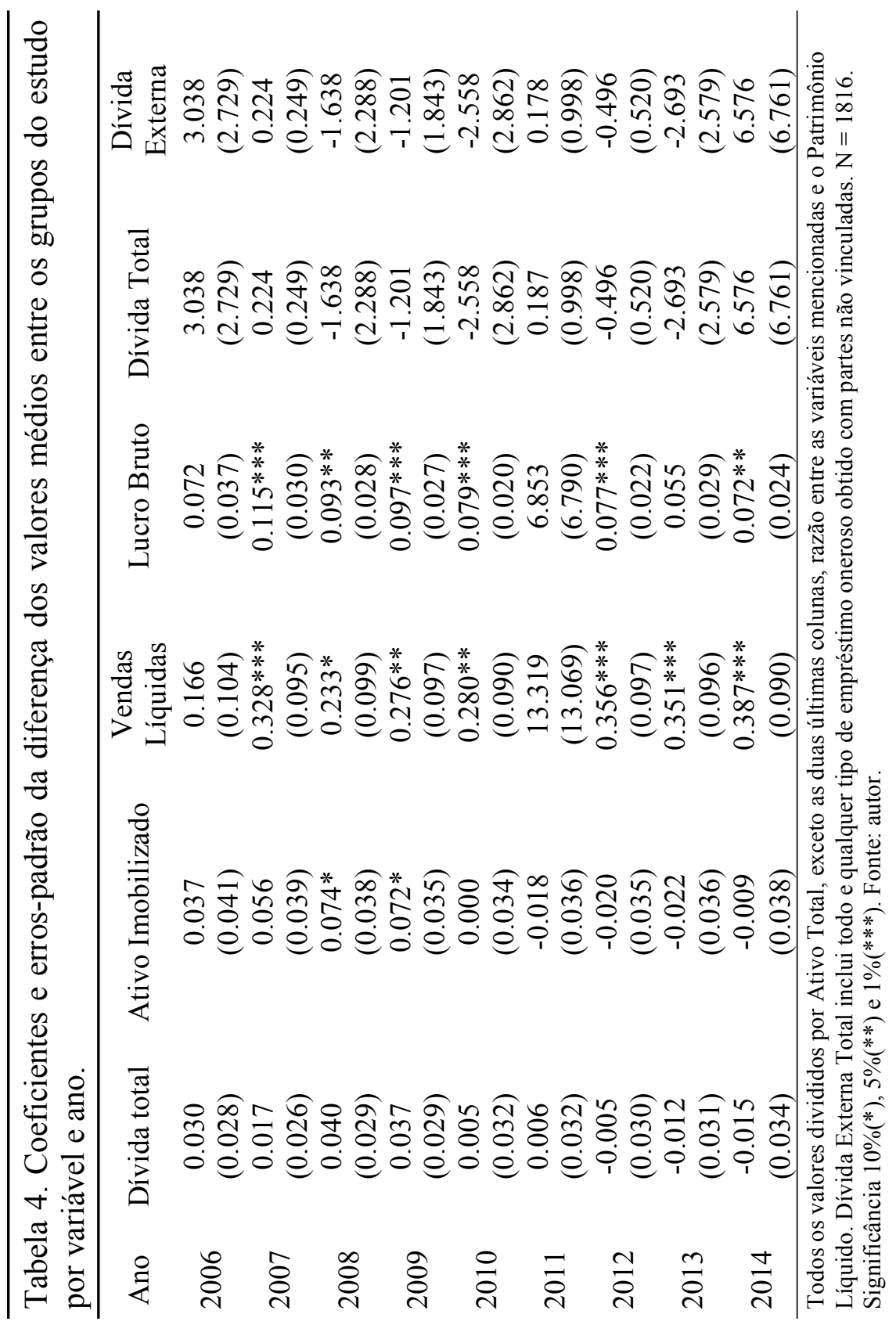




\section{Seção V - Resultados e análise}

Estudos que buscam avaliar efeitos de políticas sobre determinado grupo de indivíduos estão sujeitos à existência de viés de seleção como efeito de variáveis não observadas que potencialmente exercem, com intensidades diferentes, influência sobre os grupos analisados. $\mathrm{O}$ fato de que um dado número de empresas pertence ao grupo sujeito aos efeitos de uma política estabelecida encontra-se, em parte, sujeito à discricionariedade de sua própria administração, o que pode determinar certo grau de endogeneidade inerente aos modelos estimados.

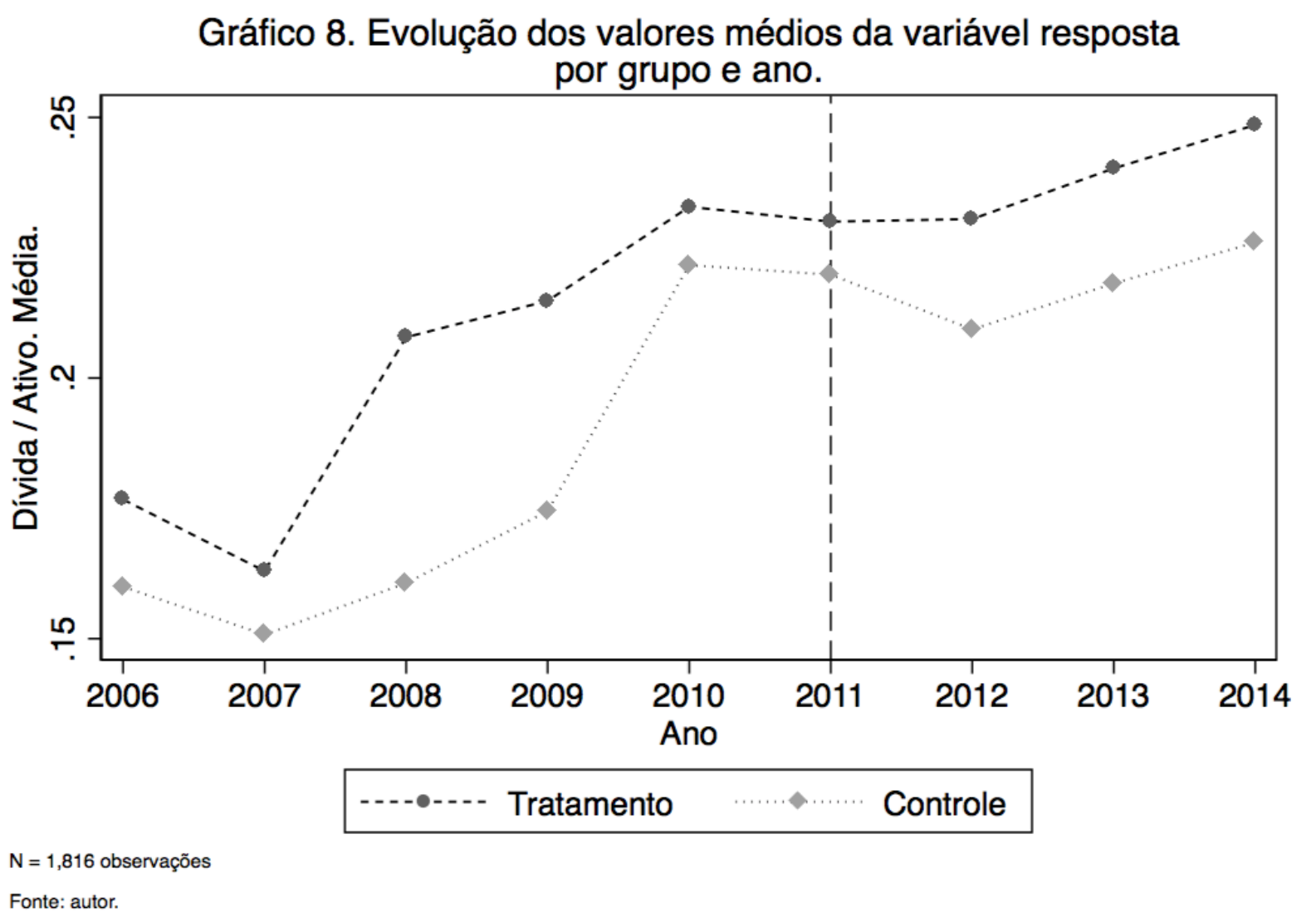

Por outro lado, a premissa chave do método de diferenças em diferenças é que o efeito secular sobre a variável dependente seria o mesmo entre os grupos antes da intervenção, caso a lei não existisse. Especialmente, que os grupos sejam diferentes em função de que as empresas que os constituem são diferentes no que tange às características observadas é admissível, mas lida-se com a possível endogeneidade neste caso por meio da certificação de que as variações observadas nos grupos antes do evento são semelhantes, ou seja, de que aqueles efeitos seculares são percebidos com a mesma intensidade em ambos os grupos. 
Para verificar a qualidade do grupo controle na condição de contrafactual, ou seja, para evidenciar o grau de similaridade das tendências de reação de ambos os grupos a variáveis observadas e não observadas na ausência da lei, encontram-se, no Gráfico 8, os valores médios da variável dependente em série temporal anual e segregada por grupo. Pode ser observado que, até o ano de 2011, as mudanças anuais médias nos dois grupos seguem tendência semelhante, embora a heterogeneidade da evolução das curvas não possa ser, pronta e adequadamente, avaliada por meio deste gráfico.

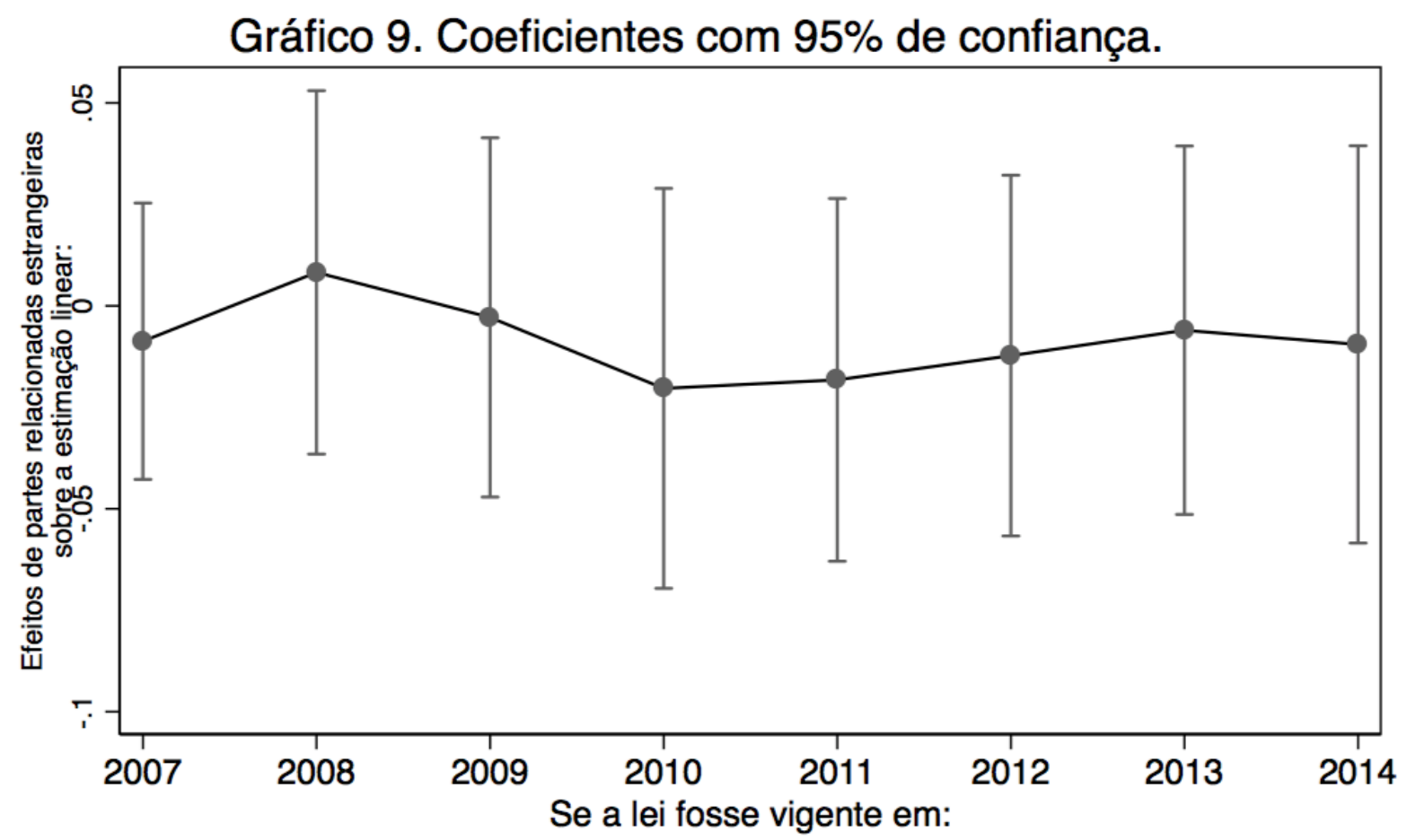

Notas: este gráfico mostra os resultados de um teste do tipo placebo para verificar a premissa de 'tendências paralelas', em que se demonstra a inexistência de efeitos da presença de partes vinculadas estrangeiras sobre a variável resposta em períodos anteriores ao tratamento. Valores do eixo y correspondem ao efeito parcial identificado, anualmente, como função da designação ao grupo tratamento e em relação ao ano de 2006 . Espera-se que, antes de 2011, os valores estimados sejam não significantes estatisticamente.

Fonte: autor.

Neste contexto, a Tabela 5 e o Gráfico 9 evidenciam os coeficientes de um teste do tipo placebo, em que cada ano do período analisado é avaliado, de forma simulada, como se fosse o ano da intervenção. O período de referência (ano-base) dos coeficientes estimados é o primeiro da série, ou seja, o de 2006 (Angrist \& Pischke, 2009, p. 238; Linden, 2015) e os intervalos de 95\% de confiança no Gráfico 9 sempre incluem o valor zero. Este teste compara um período pré-intervenção, de referência, a uma intervenção fictícia em cada um dos períodos posteriores. O que se espera é que os coeficientes não sejam significantes em períodos anteriores a 2011, mas, a lei exerça efeitos sobre o grupo tratamento, uma estimação significante seria observada no ano de 201. Como resultado, os coeficientes das interações entre dummies de ano e dummy de grupo tratamento não são estatisticamente significantes em qualquer ano fiscal do período 
analisado, impossibilitanto rejeitar a hipótese de igualdade das tendências dos grupos antes do evento.

\begin{tabular}{|c|c|c|c|c|c|c|}
\hline Ano & Variação & Erro Padrão & $\mathrm{z}$ & $\mathrm{P}>|\mathrm{z}|$ & \multicolumn{2}{|c|}{ Intervalo $95 \%$} \\
\hline 2007 & -0.0087 & 0.0174 & -0.500 & 0.616 & -0.0428 & 0.0253 \\
\hline 2008 & 0.0082 & 0.0228 & 0.360 & 0.718 & -0.0365 & 0.0530 \\
\hline 2009 & -0.0029 & 0.0226 & -0.130 & 0.899 & -0.0471 & 0.0414 \\
\hline 2010 & -0.0203 & 0.0251 & -0.810 & 0.419 & -0.0696 & 0.0289 \\
\hline 2011 & -0.0182 & 0.0228 & -0.800 & 0.424 & -0.0629 & 0.0264 \\
\hline 2012 & -0.0123 & 0.0227 & -0.540 & 0.589 & -0.0567 & 0.0322 \\
\hline 2013 & -0.0060 & 0.0232 & -0.260 & 0.795 & -0.0514 & 0.0394 \\
\hline 2014 & -0.0095 & 0.0250 & -0.380 & 0.704 & -0.0584 & 0.0394 \\
\hline
\end{tabular}

Notas: apresenta o coeficiente da interação entre dummy do ano em questão e uma indicadora de pertencimento ao grupo de tratamento. A não significância estatística indica inexistência de efeito observado em relação ao ano referência de 2006, fornecendo evidência da comparabilidade entre os grupos. $\mathrm{N}=1,816$ observações. Fonte: autor.

A estimação robusta quanto a heteroscedasticidade dos modelos empregados para identificar o efeito da lei no ano de início de sua vigência foi realizada empregando painel balanceado conforme descrito anteriormente. A razão para emprego de uma amostra menor e balanceada consiste de, principalmente, o fato de que algumas empresas da amostra completa não existiam antes do ano de 2011 , bem como outras passaram a ter deixaram de ter partes vinculadas estrangeiras durante o período analisado. Portanto, estas empresas foram excluídas da amostra. Os resultados da estimação dos modelos se encontram na Tabela 6 , enquanto que a Tabela 7 apresenta os mesmos modelos estimados com efeitos fixos. Verifica-se que a inclusão de controles não contribuiu para alteração do sinal ou significância estatística dos coeficientes estimados, mas eleva a variância dos resíduos obtidos entre as empresas, o que se verifica pela estatística rhô na Tabela 7 e atesta, como era de se esperar em uma comparação de dois grupos distintos, as diferenças existentes entre as empresas. No entanto, a inclusão de variáveis de controle indicadoras de setor não exerceu efeitos sobre os resultados ora evidenciados. O efeito estimado permaneceu negativo, próximo de zero, estatisticamente não significante e, por isso, não foi tabulado, embora ateste impossibilidade de rejeitar, no contexto desta amostra, a hipótese nula de inexistência de efeitos da lei sobre a variável dependente. 
Tabela 6 - Coeficientes e estatísticas estimadas por meio de OLS.

\begin{tabular}{|c|c|c|c|}
\hline Variável & Modelo 1 & Modelo 2 & Modelo 3 \\
\hline \multirow{2}{*}{ Interação grupo x período pós-evento } & -0.017 & -0.005 & -0.005 \\
\hline & $(-0.93)$ & $(-0.30)$ & $(-0.29)$ \\
\hline \multirow{2}{*}{ Grupo tratamento } & 0.029 & 5.234 & 4.999 \\
\hline & -1.07 & -0.48 & -0.48 \\
\hline \multirow{2}{*}{ Período pós-evento } & $0.050 * * *$ & -0.001 & -0.001 \\
\hline & -3.67 & $(-0.12)$ & $(-0.12)$ \\
\hline \multirow{2}{*}{$\mathrm{tt}$} & & -0.003 & -0.002 \\
\hline & & $(-0.47)$ & $(-0.48)$ \\
\hline \multirow{2}{*}{ Ativo Imobilizado / Ativo Total } & & & -0.013 \\
\hline & & & $(-1.30)$ \\
\hline \multirow{2}{*}{ Vendas Líquidas / Ativo Total } & & & 0.003 \\
\hline & & & -1.09 \\
\hline \multirow{2}{*}{ Patrimônio Líquido / Ativo Total } & & & -0.019 \\
\hline & & & $(-1.90)$ \\
\hline \multirow{2}{*}{ Lucro Bruto / Ativo Total } & & & -0.009 \\
\hline & & & $(-1.15)$ \\
\hline \multirow{2}{*}{ Constante } & $0.146 * * *$ & $-22.802 * *$ & $-48.660 *$ \\
\hline & -6.95 & $(-3.02)$ & $(-2.52)$ \\
\hline $\mathrm{N}$ & 1026 & 1026 & 1026 \\
\hline $\mathrm{R}^{2}$ & 0.018 & 0.023 & 0.346 \\
\hline
\end{tabular}

Notas: esta tabela apresenta os coeficientes e estatísticas t da estimação por meio de OLS. A primeira linha exibe o efeito estimado. Três modelos foram estimados. "Modelo 1" se refere à regressão da variável resposta sobre a variável binária de grupo, a variável binária de período (antes ou após a lei) e a interação entre estas duas. "Modelo 2" consiste do anterior, com a adição de tendências seculares ( $\mathrm{tt}$ ) ou seja, uma interação entre a variável de grupo e uma variável binária que identifica o ano da observação. Esta interação possibilita identificar a direção do efeito parcial de políticas não observadas sobre a variável resposta no grupo tratamento. "Modelo 3" consiste do anterior, mas adicionadas variáveis de controle, cujos coeficientes, por sua vez, foram estimados também considerando a tendência temporal por meio de interação entre uma variável contínua de ano e as próprias variáveis de controle, que consistem de valores médios por empresa antes da intervenção até o ano de 2009. Total de empresas: 114, sendo 70 tratadas. Os erros-padrão foram agrupados por empresa. Significância $1 \%(* * *), 5 \%(* *)$ e $10 \%(*)$. Fonte: autor.

Para fins de verificação de robustez destes resultados e mitigar efeitos de viés de seleção ${ }^{9}$ na estimação, o efeito foi estimado adicionalmente por meio de pareamento das empresas usando um propensity score como critério.

\footnotetext{
${ }^{9}$ Estudos comparativos de natureza quasi-experimental se fundamentam no fato de que o potencial de efeitos da não intervenção é o mesmo entre os grupos. O viés de seleção ocorre quando existe diferença neste potencial entre os dois grupos, elevando ou reduzindo o efeito observado, compromentendo a estimação do efeito da lei. Em exemplo, Angrist e Pischke (2009, p. 14) assertam que "é mais provável que pessoas doentes busquem tratamento hospitalar, o que faz com que sua condição média de saúde seja inferior à daquelas que não o buscam”, o que torna o viés de seleção negativo neste exemplo. O que o DD e o PSM possibilitam é a redução deste viés de seleção por meio de, ao serem atendidas as premissas destes métodos, tornar a variável dependente observada independente da designação de cada unidade observacional a um ou a outro grupo.
} 
Estimar efeito de tratamentos com o auxílio de propensity score matching equivale a ajustar o desenho dos testes realizados por meio do controle das diferenças observadas antes do tratamento, provendo uma representação simples dos dados, reduzindo a variância da estimativa do efeito do tratamento e produzindo modelos mais robustos (Rosenbaum \& Rubin, 1983). O objetivo consiste da obtenção de amostras em que os indivíduos tratados e não tratados comparados para a estimação do efeito do tratamento são tão semelhantes quanto possível, condicional ao propensity score.

Tabela 7 - Coeficientes e estatísticas estimadas por meio de OLS e Efeitos Fixos.

\begin{tabular}{rccc}
\hline Variável & Modelo 1 & Modelo 2 & Modelo 3 \\
\hline Efeito estimado & -0.017 & -0.005 & -0.005 \\
& $(-0.92)$ & $(-0.30)$ & $(-0.29)$ \\
& & -0.003 & -0.002 \\
& & $(-0.47)$ & $(-0.47)$ \\
At & & & -0.013 \\
Ativo Imobilizado / Ativo Total & & & $(-1.30)$ \\
& & & 0.004 \\
Vendas Líquidas / Ativo Total & & -1.09 \\
& & -0.009 \\
Lucro Bruto / Ativo Total & & & $-1.15)$ \\
& & & -0.019 \\
Patrimônio Líquido / Ativo Total & & $-1.89)$ \\
& & & $-18.009 * *$ \\
Constante & $0.156^{* * *}$ & 3.348 & $(-3.36)$ \\
& -13.67 & -0.5 & 0.9999 \\
Rho & 0.7126 & 0.9987 & 1026 \\
$\mathrm{~N}$ & 1026 & 1026 & 0.102 \\
\hline
\end{tabular}

Notas: esta tabela apresenta os coeficientes e estatísticas da estimação por meio de OLS com efeitos fixos de tempo e empresa. A primeira linha exibe o efeito estimado. Três modelos foram estimados. "Modelo 1" se refere à regressão da variável resposta sobre a variável binária de grupo, a variável binária de período (antes ou após a lei) e a interação entre estas duas. "Modelo 2" consiste do anterior, com a adição de tendências seculares (tt) ou seja, uma interação entre a variável de grupo e uma variável binária que identifica o ano da observação. Esta interação possibilita identificar a direção do efeito parcial de políticas não observadas sobre a variável resposta. "Modelo 3" consiste do anterior, mas adicionadas variáveis de controle, cujos coeficientes, por sua vez, foram estimados também considerando a tendência temporal por meio de interação entre uma variável contínua de ano e as próprias variáveis de controle, que consistem de valores médios por empresa antes da intervenção até o ano de 2009. Rho é a correlação intraclasse, a fração da variância dos erros que se deve às diferenças entre as empresas. Total de empresas: 114 , sendo 70 tratadas. Os erros-padrão foram agrupados por empresa. Significância $1 \%(* * *), 5 \%(* *)$ e $10 \%(*)$. Fonte: autor. 
Este cenário é obtido por meio do cálculo de indicadores, scores, a partir das variáveis observadas e comparação entre aquelas unidades que possuem scores próximos entre si, fazendo com que, condicional a cada valor do score, a distribuição das variáveis que o determinam é a mesma para os dois grupos de observações, aproximando a avaliação de um experimento aleatório condicional às variáveis empregadas na estimação do score (Stuart, 2010). Uma vez calculados os valores dos scores, as companhias foram pareadas conforme processos denominados procedimentos de matching. Estes processos consistem de algoritmos que empregam critérios distintos ao parear as unidades observacionais. Por definição, PSM consiste de um método que exige grande quantidade de dados, especialmente em função do estabelecimento da região de common support ${ }^{10}$ no cálculo do propensity score e dos processos de matching. Quanto maior a quantidade de variáveis controle que determinam a probabilidade condicional de receber o tratamento, maior é a quantidade de observações sem pares (Heckman, Ichimura, \& Todd, 1998). Os resultados obtidos na estimação com o emprego de pareamento por PSM encontram-se na Tabela 8.

\begin{tabular}{rcccc}
\hline \multicolumn{5}{l}{ Tabela 8 - Estimação após pareamento por propensity score, por método. } \\
\hline & One-to-One & $\begin{array}{c}\text { Nearest } \\
\text { neighbor }\end{array}$ & Radius & Kernel \\
\hline Efeito estimado da lei & -0.0329 & -0.0190 & -0.0375 & -0.0417 \\
Erro-padrão & 0.0271 & 0.0234 & 0.0257 & 0.0268 \\
Valor-p & 0.2248 & 0.4147 & 0.1448 & 0.1200 \\
Empresas tratadas & 35 & 53 & 53 & 53 \\
Empresas controle & 35 & 35 & 35 & 35 \\
\hline
\end{tabular}

Notas: Efeito estimado da lei por método de matching. One-to-one permite pareamento de um indivíduo controle com cada empresa tratada, sem reposição dos controles uma vez que já foram pareados. Nearest neighbor calcula a média ponderada dos dez controles mais próximos do indivíduo tratado em análise, permitindo reposição dos controles a cada procedimento de matching. Radius permite o pareamento de controles dentro de um caliper (distância) de até 10\% do score calculado para o indivíduo tratado a ser pareado, atribuindo, como no método nearest neighbor, pesos iguais aos controles usados. Kernel pondera o efeito estimado do contrafactual por meio da distância observada, em termos do score calculado, entre a empresa tratada e os indivíduos do grupo controle, atribuindo, aos controles que se encontram dentro de determinada faixa, pesos proporcionais à essa distância. N: 1,026 observações, 114 empresas. Fonte: autor.

Os Quadros 1e 2, ilustram a semelhança da distribuição do propensity score das observações pertencentes à região de common support, enquanto o Guadro 3 apresenta a

\footnotetext{
${ }^{10}$ Região de sobreposição das distribuições do propensity score dos dois grupos. Nesta região, encontram-se observações ditas comparáveis, pois o respectivo valor do PS pode ser observado nos dois grupos.
} 
distribuição das variáveis em formato de box plot, provendo suporte à confirmação do balanceamento das variáveis após o pareamento das empresas para estimação do efeito da lei. Nos Quadros "1" e "2", cada linha de gráficos representa um ano, partindo de 2006 até 2009. Nestes, em que os quantis das variáveis são contrapostos aos da distribuição normal, busca-se verificar a semelhança de cada respectivo gráfico entre os dois Quadros.

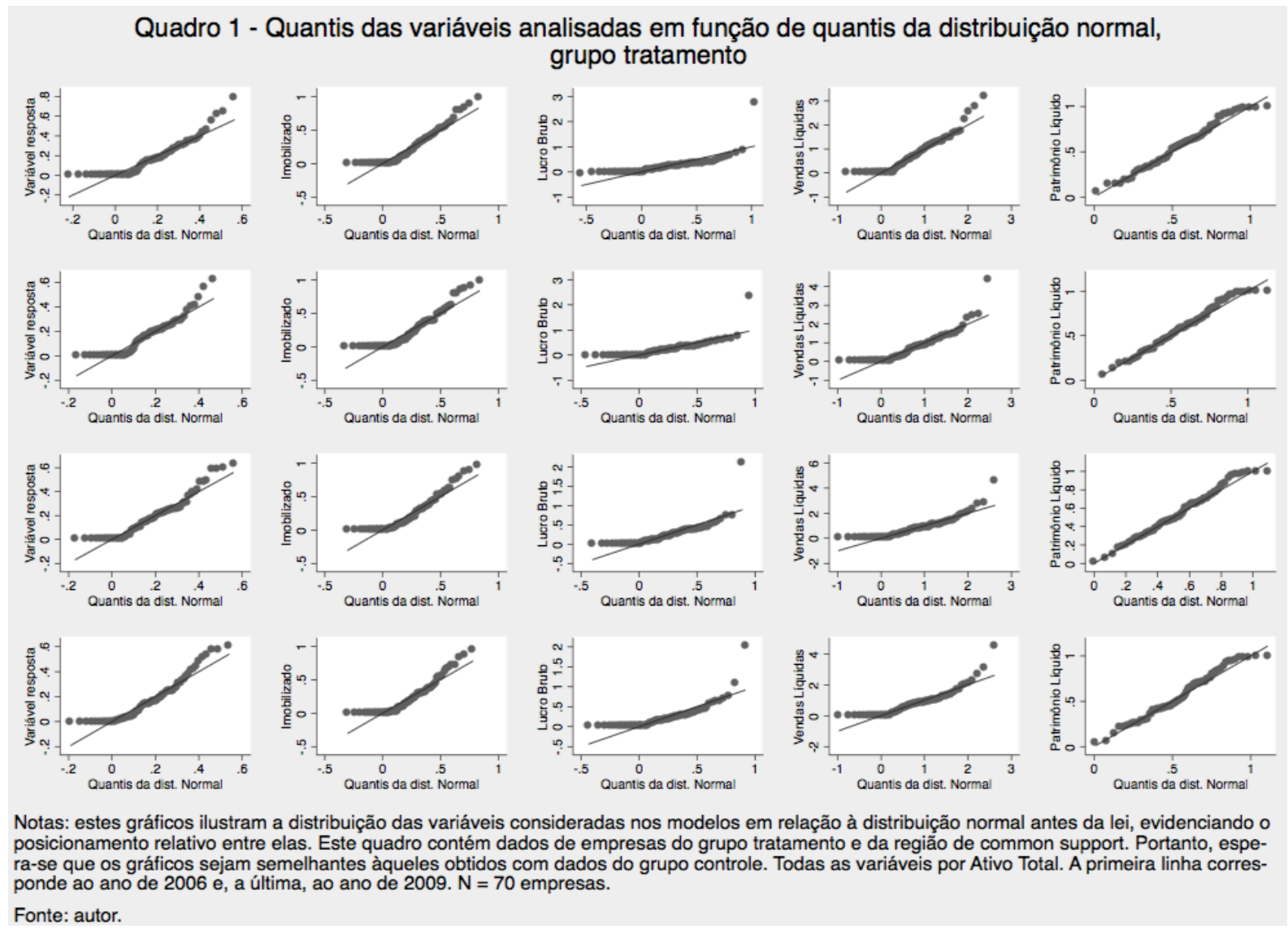

No Quadro 3 busca-se observar valores médios e dispersão semelhantes entre os grupos. Conforme mencionado nas seções anteriores, é possível que, no ano de 2010, dada a possibilidade legal, a lei pode ter exercido efeitos sobre a CSLL ainda neste ano. Portanto, excluir os valores observados referentes ao ano de 2010, tanto da variável resposta quanto das de controle, possibilita a identificação do efeito da intervenção no ano de 2011 em relação a 2009. Para fins de avaliar a robustez das conclusões deste trabalho, quatro procedimentos de matching foram empregados: one-to-one matching, $k$ nearest neighbor matching, radius matching e kernel matching (Heckman et al., 1998; Leuven \& Sianesi, 2003), os quais, gradativamente, permitem uma distância cada vez maior, considerando o indivíduo tratado para o qual se busca um contrafactual, na inclusão dos pares encontrados no grupo controle. 
Quadro 2 - Quantis das variáveis analisadas em função de quantis da distribuição normal, grupo controle
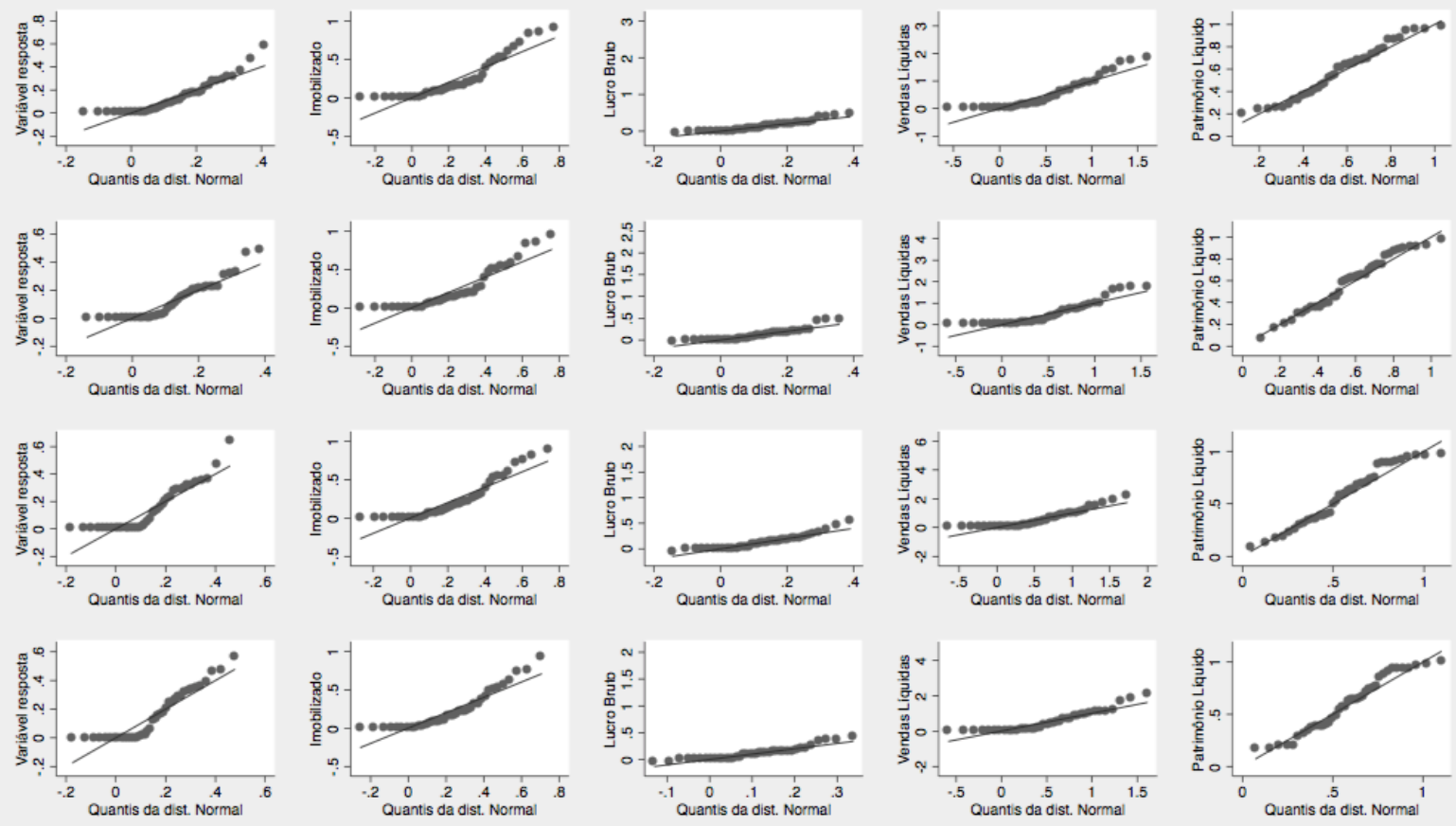

Notas: estes gráficos ilustram a distribuição das variáveis consideradas nos modelos em relação à distribuição normal antes da lei, evidenciando o posicionamento relativo entre elas. Este quadro contém dados de empresas do grupo controle e da região de common support. Portanto, espera-se que os gráficos sejam semelhantes àqueles obtidos com dados do grupo tratamento. Todas as variáveis por Ativo Total. A primeira linha corresponde ao ano de 2006 e, a última, ao ano de 2009 . $\mathrm{N}=44$ empresas.

Fonte: autor.

O primeiro método, com apenas uma combinação de indivíduo controle por tratado, calcula a diferença observada da variável de interesse entre o indivíduo tratado e o controle que tiver score mais próximo. O segundo método busca $k$ empresas cujos scores se aproximam da tratada para quem se procura um contrafactual e calcula a média ponderada, com pesos idênticos entre si, dos valores observados da variável dependente das $k$ empresas obtidas. Esta média ponderada é empregada como contrafactual para a estimação do efeito do tratamento na empresa tratada em questão. Neste estudo, adotou-se um número de dez empresas nearest neighbors para a obtenção do resultado ponderado. Por sua vez, o terceiro método, radius, busca empresas não tratadas dentro de um intervalo relativo ao desvio-padrão do score, medido a partir da empresa tratada sendo pareada. Por fim, o método kernel emprega ponderação no cálculo do valor usado como contrafactual da empresa sendo pareada. Esta ponderação se dá por meio da distância observada a partir da empresa tratada, ou seja, quanto mais longe, menor é o peso (Garrido et al., 2014; Handouyahia, Haddad, \& Eaton, 2013).

Todas as estimações realizadas por meio de matching ocorreram por meio de regressão logística, para estimação do score, e bootstrapping com cem repetições para cálculo do efeito estimado, embora este procedimento não tenha resultado em estatísticas que alterassem a 
significância dos resultados obtidas com a amostra inicial deste procedimento. As variáveis de controle empregadas na estimação do propensity score foram as mesmas da seção anterior, apresentadas na Tabela 6 , enquanto que a variável dependente na estimação do efeito do tratamento, quando realizada por meio do PSM, foi a diferença observada na variável dependente dos modelos anteriores entre os períodos de 2011 e 2009.

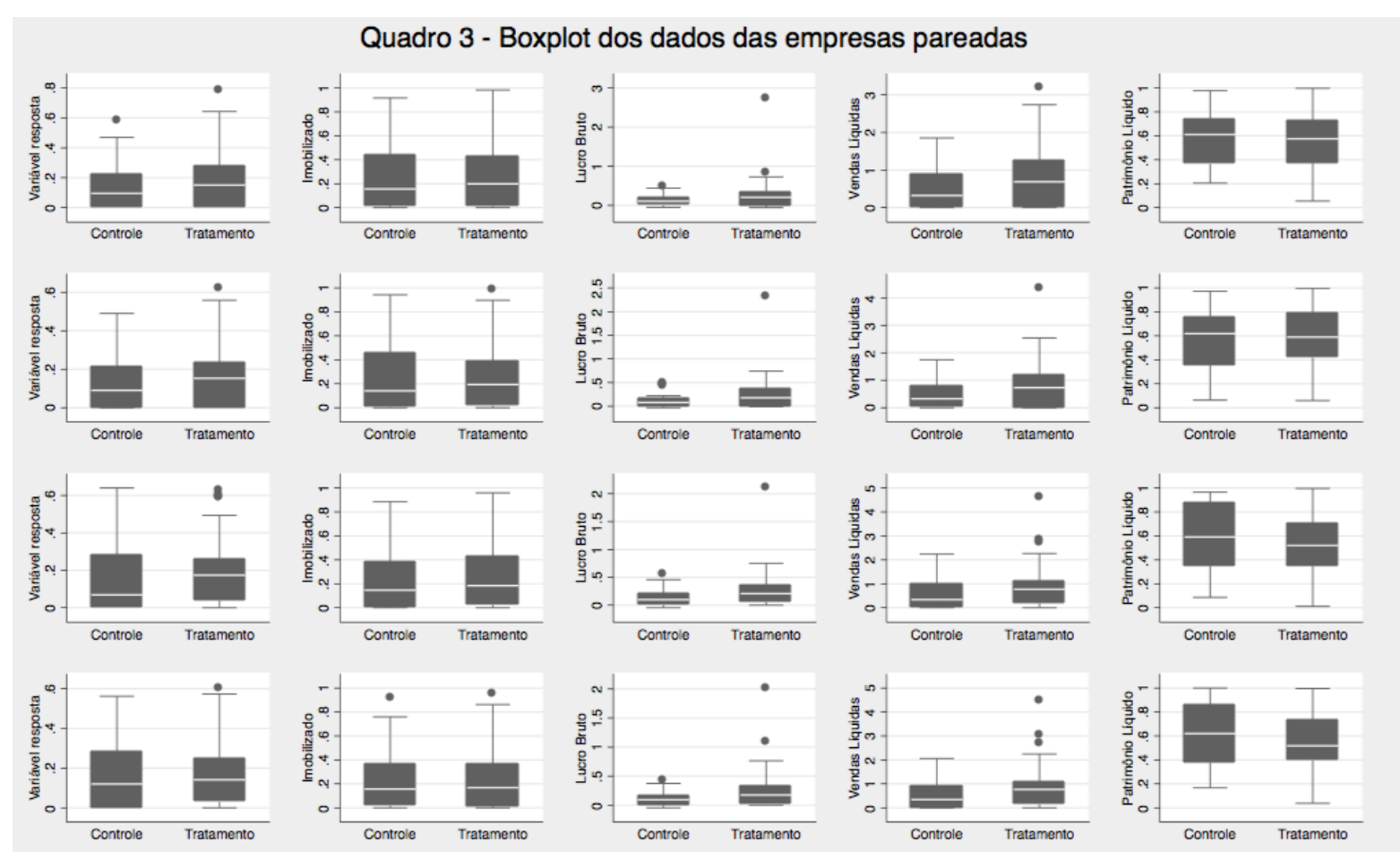

Notas: estes gráficos ilustram a distribuição das variáveis consideradas nos modelos, por grupo, evidenciando a média, quartis e valores extremos das empresas pareadas observados antes da vigência da lei. Tal qual no Quadro 1, apenas dados de empresas da região de 'common support' antes da lei constam neste gráfico. O posicionamento semelhantes das estatísticas dos gráficos fornecem evidência do balanceamento das variáveis e, por conseseguinte, da comparabilidade dos grupos. A primeira linha representa o ano de 2006 e, a última, 2009. $\mathrm{N}=456$ observações, 114 empresas.

Fonte: autor.

A estimação do efeito ora investigado é realizada, após o pareamento, por meio do cálculo da diferença observada entre as unidades pareadas. Apenas unidades que apresentam propensity score contido em determinado intervalo são usadas nesta estimação. O intervalo em questão, ou a região de common support, é determinado de forma que seja estabelecido, condicional às variáveis observadas, grau máximo possível de semelhança entre os grupos obtidos, o que se denomina balancing property. Este intervalo foi determinado de forma a conter as unidades que apresentassem score contido entre 0,208663 e 0,999941, inclusive, e contém 945 observações, das quais 315 pertencem a 35 empresas do grupo controle e, 630, a 70 empresas do grupo tratamento.

O Quadro 4 apresenta gráficos comparativos das tendências da variável dependente deste estudo após o pareamento por meio do PSM. Pode ser observado que as variáveis possuem tendências semelhantes entre os grupos. Por sua vez, o eixo “y” dos gráficos contidos no Quadro 
5 apresenta, empregando os dados contidos na região de common support e estimação com emprego de PSM, os efeitos parciais estimados no teste placebo conforme definido anteriormente. Estes coeficientes avaliam o efeito de uma hipotética intervenção a cada ano do período.

\section{Quadro 4 - Valores médios anuais por grupo e método de matching Verificação das tendências}
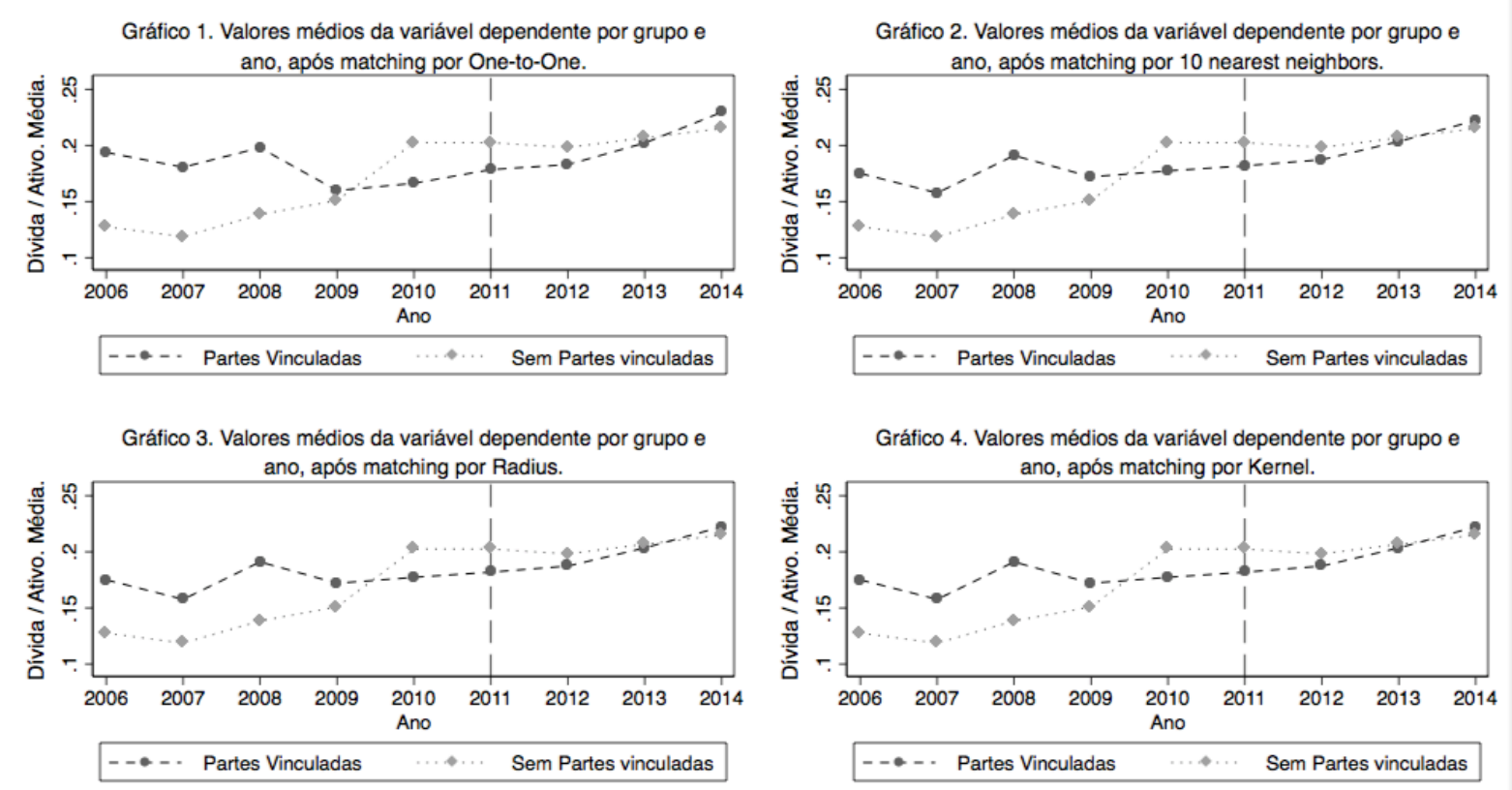

Este quadro ilustra as curvas formadas por valores médios da variável resposta dos dois grupos a cada ano. São apresentados dados de um painel balanceado que, obtido da amostra anterior, comporta observações oriundas de empresas que não mudaram de grupo e que pertencem à região de common support, considerando cada respectivo método de estimação do PS. As quantidades de observações empregadas foram 630 (One-to-one) e 792 em cada um dos outros métodos de matching. Do total de empresas do painel balanceado (114), 26 não foram usadas em qualquer estimação com emprego de PSM.

Fonte: autor.

Identificar alterações significantes na variável resposta a qualquer ano anterior a 2011 invalidaria a premissa de tendências paralelas e comparabilidade dos grupos. No entanto, não foram observadas diferenças significantes, o que não contribui com evidências de que a variável resposta apresenta comportamento diferente entre os grupos no período pré-intervenção. Adicionalmente, não são verificados coeficientes significantes após o ano de 2011, inclusive, o que também não contribui para constatar que a lei exerceu efeito sobre a variável resposta no grupo tratamento. Em alinhamento com o método descrito anteriormente, a avaliação do efeito da lei por meio do propensity score matching não apresentou evidências significantes de relação de causa e efeito entre a legislação e a variável dependente. Ainda, contribuiu para o entendimento de que os grupos são comparáveis, especialmente quando os indivíduos são pareados por um dos quatro métodos ora empregados. 


\section{Quadro 5 - Teste placebo por método de matching}
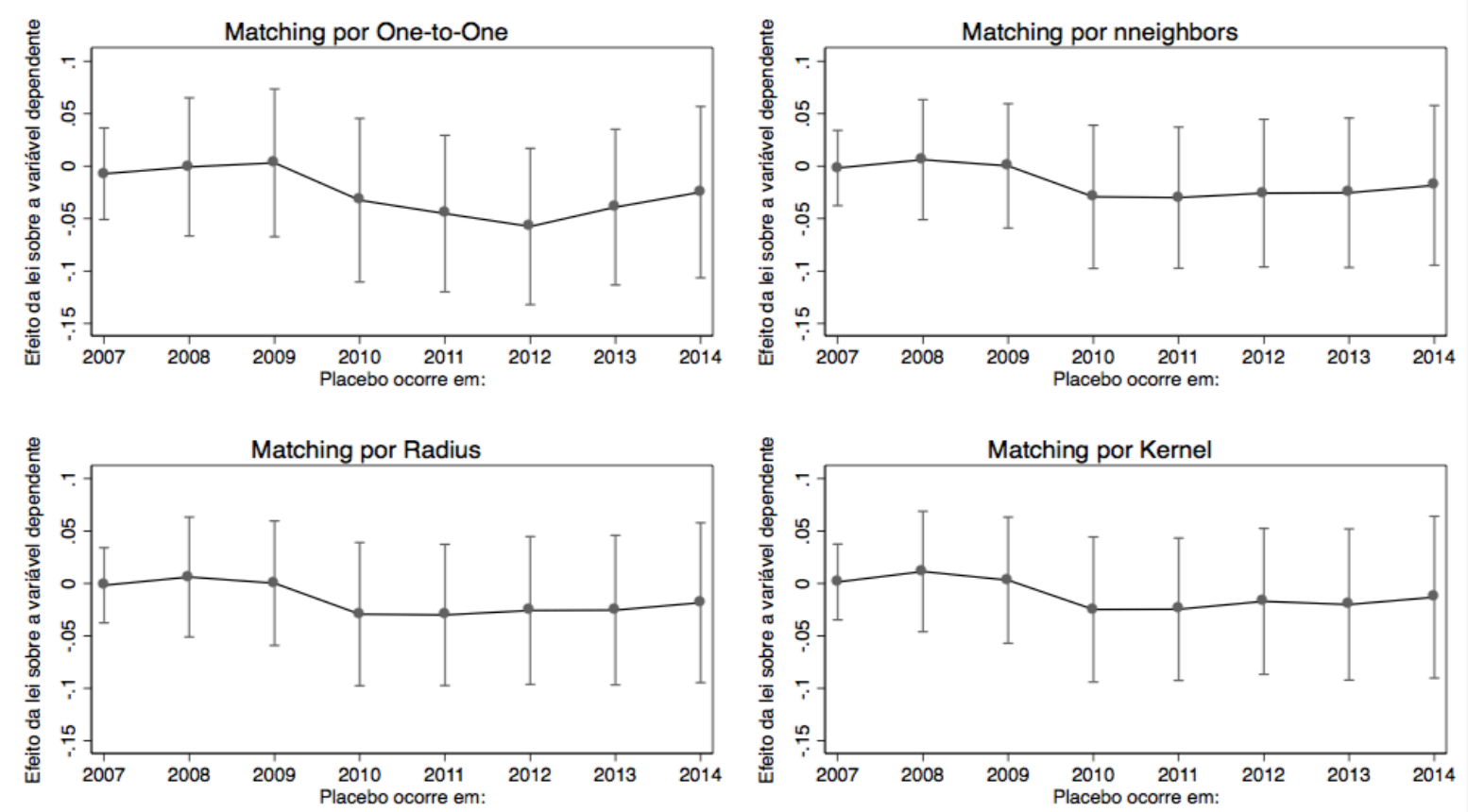

Notas: Estes gráficos mostram o efeito estimado do tratamento em relação ao ano de 2006 caso a intervenção tivesse ocorrido em um ano qualquer. Coeficientes não significantes são esperados durante o período anterior a 2011 e, caso ocorram após este ano, constituem evidência em favor da inexistência de efeito da lei sobre a variável resposta. A linhas verticais informam o intervalo de confiança de $95 \%$, enquanto que o eixo ' $y$ ' denota o valor estimado do coeficiente caso a intervenção tivesse ocorrido no ano listado no eixo ' $x$ '. Dados de empresas pareadas conforme respectivo método de matching.

Fonte: autor

As diferentes proporções observadas no grupos comparados, tanto em termos de frequência quanto de variáveis observadas, podem ter seus efeitos mitigados por meio do emprego de ponderação no cálculo dos estimadores. Estimação do efeito de tratamentos sobre os tratados por meio do pareamento com PSM também tem sido descrita no contexto de ponderação de regressões lineares (Linden \& Adams, 2011), embora Leuven e Sianesi (2003) ressaltem inexistência de consenso acerca de como empregar pesos para ponderar amostras quando usados processos de matching. A abordagem de ponderação dos dados em combinação com matching pode agregar contribuições úteis em comparações com outros métodos. Em comparação com outros desenhos de pesquisa quasi-experimental, como variáveis instrumentais (IV), regressão descontínua (RDD) e métodos de painel, a ponderação de variáveis controle apresenta maior flexibilidade em relação aos métodos de painel e maior eficiência com menor viés, em relação a IV e RDD. Nichols (2007) descreve como a ponderação dos grupos sendo comparados pode tornar menores as diferenças entre as distribuições de suas variáveis explicativas e sugere a comparação de resultados prévios com estimadores obtidos por meio de, por exemplo, regressão com uso de efeitos fixos. Este procedimento foi realizado neste estudo e os pesos empregados foram os da Equação 4 caso a empresa pertença ao grupo controle e $w=1$, caso contrário (Nichols, 2008). 


$$
w=p s /(1-p s)
$$

Nesta expressão, $w$ representa "peso" e, ps, o score obtido para cada observação. Os estimadores obtidos por meio de regressão ponderada com uso do PSM em painel balanceado sem empresas que alternem entre grupos encontram-se na Tabela 9 e devem ser comparados com as Tabelas 6 e 7. Pode ser verificado que, mesmo atribuindo pesos maiores a empresas do grupo controle que possuem valores mais altos em seus scores estimados, não se verifica alteração no sinal e significância dos coeficientes, bem como que a adição de controles relacionados a características das empresas não alterou os coeficientes das estimações que controlaram por tendências seculares.

Tabela 9 - Efeito estimado da lei sobre empresas que possuem partes vinculadas estrangeiras, por método de estimação.

\begin{tabular}{|c|c|c|c|c|}
\hline \multirow[b]{2}{*}{ DD padrão } & ATT & Std-err & t-stat & p-value \\
\hline & \multirow[b]{2}{*}{-0.0214} & \multirow[b]{2}{*}{0.0187} & \multirow[b]{2}{*}{-1.1471} & \multirow[b]{2}{*}{0.2538} \\
\hline OLS ponderado & & & & \\
\hline OLS ponderado com EF & -0.0214 & 0.0187 & -1.1437 & 0.2552 \\
\hline DD e efeitos de tempo & & & & \\
\hline OLS ponderado & -0.0067 & 0.0208 & -0.3215 & 0.7485 \\
\hline OLS ponderado com EF & -0.0067 & 0.0209 & -0.3207 & 0.7491 \\
\hline
\end{tabular}

Controles e efeitos de tempo

$\begin{array}{lllll}\text { OLS padrão } & -0.0067 & 0.0209 & -0.3202 & 0.7494 \\ \text { OLS ponderado com EF } & -0.0067 & 0.0209 & -0.3207 & 0.7488\end{array}$

\begin{abstract}
ATT: average treatment effect on the treated, ou efeito médio do tratamento sobre os tratados, seguido das colunas, erro-padrão, estatística $t$ de Student e valor $p$. A seção superior consiste de estimação do modelo de diferença-em-diferenças na forma de interação de dummies de tratamento e período (antes ou depois), sem controles. As seções seguintes consistem de, respectivamente, o modelo prévio descrito mais tendência temporal da variável resposta no grupo tratamento, na seção intermediária, e controles com tendência temporal, na seção inferior. Cada seção teve seu respectivo modelo estimado no formato padrão com erros robustos, agrupados por empresa, e com efeitos fixos ponderação conforme descrição no texto. $\mathrm{N}=1,026$ observações, 114 empresas.
\end{abstract}

Dado o objetivo da medida avaliada, coibir medidas "agressivas" de planejamento tributário ao restringir os benefícios obtidos por meio da obtenção de empréstimos 
intercompanhia oriundos de partes vinculadas estrangeiras, observar coeficientes negativos na estimação do efeito da lei sobre a estrutura do financiamento das atividades das empresas do grupo tratamento deste estudo contribui para o entendimento da natureza do efeito da lei sobre a variável dependente. $\mathrm{O}$ efeito estimado nos modelos tem interpretação direta a partir do coeficiente obtido. Conforme os resultados tabulados, que variaram de uma redução máxima do endividamento correspondente a $4,17 \%$ do Ativo Total na estimação com emprego do método kernel de matching, até a redução de valor que corresponde a $0,5 \%$ do Ativo Total no modelo DD com painel balanceado e variáveis de controle. O emprego de ponderação por propensity score reverteu o sinal do efeito estimado no modelo sem controles, mas a adição de variáveis de controle provocou o retorno dos coeficientes a valores negativos, sempre produzindo coeficientes não significantes aos níveis convencionais, o que suporta argumentos contrários à realização da expectativa que se tinha quanto aos efeitos da lei.

Tabela 10 - Efeito estimado da lei sobre variável resposta obtida considerando todo o capital disponível (terceiros e próprio).

\begin{tabular}{lcccc}
\hline Modelo estimado & Efeito estimado & $\mathrm{SE}$ & $\mathrm{t}$ & $\mathrm{p}$ \\
\cline { 1 - 3 } Modelo 1 & -0.0204 & 0.022 & -0.926 & 0.357 \\
Modelo 2 & -0.0191 & 0.024 & -0.804 & 0.423 \\
Modelo 3 & -0.0191 & 0.024 & -0.801 & 0.425 \\
Modelo 4 & -0.0204 & 0.022 & -0.923 & 0.358 \\
Modelo 5 & -0.0191 & 0.024 & -0.802 & 0.424 \\
Modelo 6 & -0.0191 & 0.024 & -0.801 & 0.425 \\
Modelo 7 & 0.0568 & 0.040 & 1.432 & 0.155 \\
Modelo 8 & -0.1030 & 0.086 & -1.198 & 0.233 \\
Modelo 9 & -0.1030 & 0.086 & -1.193 & 0.235 \\
Modelo 10 & 0.0568 & 0.040 & 1.427 & 0.156 \\
Modelo 11 & -0.1030 & 0.086 & -1.195 & 0.234 \\
Modelo 12 & -0.1030 & 0.086 & -1.195 & 0.234 \\
\hline
\end{tabular}

Notas: esta tabela lista os coeficientes estimados no cálculo do efeito da lei considerando, como variável resposta, a composição da variável resposta conforme Wamser (2010). Modelo 1 é a estimação por OLS, Modelo 2 é o anterior acrescido da interação entre a variável de tratamento e uma indicadora de ano e, Modelo 3, o anterior acrescido das variáveis de controle, conforme tabelas anteriores. Os modelos de 4 a 6 são como os anteriores, porém estimados com efeitos fixos de empresa. Os modelos de 7 a 12 são como os anteriores, porém ponderados pelo propensity score, tal qual metodologia descrita nas tabelas anteriores. $\mathrm{N}=1,026$ observações e 114 empresas, sendo 70 do grupo tratamento e 44 do grupo controle. Fonte: autor.

Wamser (2014), ao avaliar a resposta de empresas sujeitas ao aumento de restrições para a dedutibilidade de juros relativos a dívidas intercompanhia, relata substituição de capital 
interno por externo às taxas de $18 \%$ de elevação do uso de dívida externa e $5,1 \%$ do uso desta mesma dívida em relação ao grupo contrafactual. Em sua investigação, este autor apresenta evidências significantes de elevação da parcela de dívidas externas e concomitante redução da parcela de dívida total contratadas pelas companhias analisadas, em relação aos seus Patrimônios Líquidos, e defende que a redução do endividamento total relativo, em sinergia com o aumento do endividamento externo, se deu de tal forma a corroborar a substituição de empréstimos internos por externos, embora de maneira incompleta. Resultados desta investigação ao se considerar o Patrimônio Líquido no cálculo da variável dependente encontram-se nas Tabelas 10 e 11 e referem-se à variável resposta obtida com a Equação 5, em que $\operatorname{ext}_{d}$ consiste de dívida externa total, tot $_{\text {eic }}$ é o total de empréstimos intercompanhia e equity se refere ao Patrimônio Líquido da empresa $i$ no ano $t$.

$$
y_{i t}=e^{e x t_{d_{i t}}} /\left(e x t_{d_{i t}}+\text { tot }_{\text {eic } i t}+\text { equity }_{i t}\right) \quad \text { Equação } 5
$$

Por outro lado, no presente estudo, que avaliou o endividamento em relação ao Ativo Total das companhias, verificou-se, além da redução relativa da parcela de dívida que financia o Ativo Total das empresas que possuem partes relacionadas estrangeiras, também a redução relativa, entre os grupos, da parcela de dívida externa empregada no financiamento das operações das empresas do grupo tratamento, embora ambas as reduções encontradas não sejam estatisticamente significantes aos níveis empregados. Ainda, deve-se levar em conta que a divulgação de transações com partes vinculadas tornou-se compulsória somente no ano de 2010, no que tange às obrigações de empresas não listadas em bolsa de valores, conforme norma CPC 05 do Comitê de Pronunciamentos Contábeis (CPC, 2010). Portanto, dados oriundos de Demonstrações Financeiras destas empresas agregam, ao endividamento total, aquela parcela devida a partes vinculadas, não consistindo, obrigatoriamente, exclusivamente de dívida com agentes externos ao grupo econômico da empresa em questão. Por conseguinte, embora os valores estimados sejam coerentes com os dos modelos anteriores, pouco se pode concluir ao observar estes números, dada a existência de valores intercompanhia, não segregados, na mesma conta contábil apresentada. Inexistem garantias de que os valores reportados no endividamento consistam apenas de dívida externa nas datas antes de 2010, posto que a amostra, por definição dos objetivos deste trabalho, comporta empresas públicas e de capital fechado, bem como empresas sujeitas a normas de outros países e empresas sujeitas apenas às normas brasileiras, que não determinavam a segregação destes valores em Balanço Patrimonial ou Notas Explicativas. 
Tabela 11 - Resultados do matching considerando dívida financeira onerosa por capital disponível (terceiros e próprio).

\begin{tabular}{rrrrr}
\hline & One-to-One & $\begin{array}{c}\text { Nearest } \\
\text { neighbor }\end{array}$ & Radius & Kernel \\
\hline Efeito estimado da lei & -0.0355 & -0.0277 & -0.0392 & -0.0360 \\
Erro-padrão & 0.0277 & 0.0296 & 0.0294 & 0.0277 \\
Valor-p & 0.2005 & 0.3495 & 0.1830 & 0.1944 \\
Empresas tratadas & 35 & 53 & 53 & 53 \\
Empresas controle & 35 & 35 & 35 & 35 \\
\hline
\end{tabular}

Notas: Efeito estimado da lei por método de matching. One-to-one permite pareamento de um indivíduo controle com cada empresa tratada, sem reposição dos controles uma vez que já foram pareados. Nearest neighbor calcula a média ponderada dos dez controles mais próximos do indivíduo tratado em análise, permitindo reposição dos controles a cada procedimento de matching. Radius permite o pareamento de controles dentro de um caliper (distância) de até 10\% do score calculado para o indivíduo tratado a ser pareado, atribuindo, como no método nearest neighbor, pesos iguais aos controles usados. Kernel pondera o efeito estimado do contrafactual por meio da distância observada, em termos do score calculado, entre a empresa tratada e os indivíduos do grupo controle, atribuindo, aos controles que se encontram dentro de determinada faixa, pesos proporcionais à essa distância. $\mathrm{N}=1026$ observações, 114 empresas.

Ainda, conforme Tabelas 10 e 11, não houve alteração na significância do efeito estimado do tratamento empregando a relação entre dívida onerosa e capital disponível como variável resposta (Equação 5), cujos resultados também se mostraram negativos e não significantes mesmo com a inclusão de controles. Estes resultados, embora não significantes aos níveis usuais de confiança, apresentam evidência que confirma, parcialmente, os resultados de Wamser (2014) e Overesch e Wamser (2010a). Nestes estudos, os autores encontram resultados significantes da efetividade das normas restritivas de subcapitalização na Alemanha e relatam redução da parcela de dívida total em relação ao capital total disponível para a companhia. Embora não significante estatisticamente nesta instância, esta observação também pode ser feita neste estudo. Ainda, aqueles autores também verificam redução na parcela intercompanhia da dívida e elevação da parcela que corresponde ao endividamento externo. Dado que, no Brasil, a data de ocorrência das normas contábeis relacionadas não garante assertividade dos dados no que tange a empréstimos intercompanhia em períodos anteriores a 2010, a comparação com os estudos mencionados se mostrou impossível, em virtude de que, em ambos os grupos, existem empresas que não estavam obrigadas a evidenciar estes valores antes daquele ano. Adicionalmente, a designação de empresas ao grupo tratamento seguiu critérios diferentes dos adotados naqueles trabalhos, em que foram consideradas tratadas as empresas que 
apresentassem parcela de empréstimos intercompanhia próxima ou já superior aos índices mencionados em suas respectivas legislações. Neste estudo, posto que a lei estabelece a condição de existirem partes vinculadas no exterior para que os valores fossem comparados a índices de referência, adotou-se esta condição como critério para designação ao grupo tratamento.

O endividamento absoluto das empresas apresenta tendência secular de crescimento em ambos os grupos, crescimento que parece acompanhar o aumento dos investimentos realizados no ativo, fatos que podem ser observados no Quadro 6 e na observação do crescimento da variável resposta deste estudo. Neste quadro, os gráficos evidenciam que ambas as séries, tanto da dívida das empresas quanto da relação entre dívida e capital total disponível, parecem seguir direção ascendente, embora não muito acentuada.
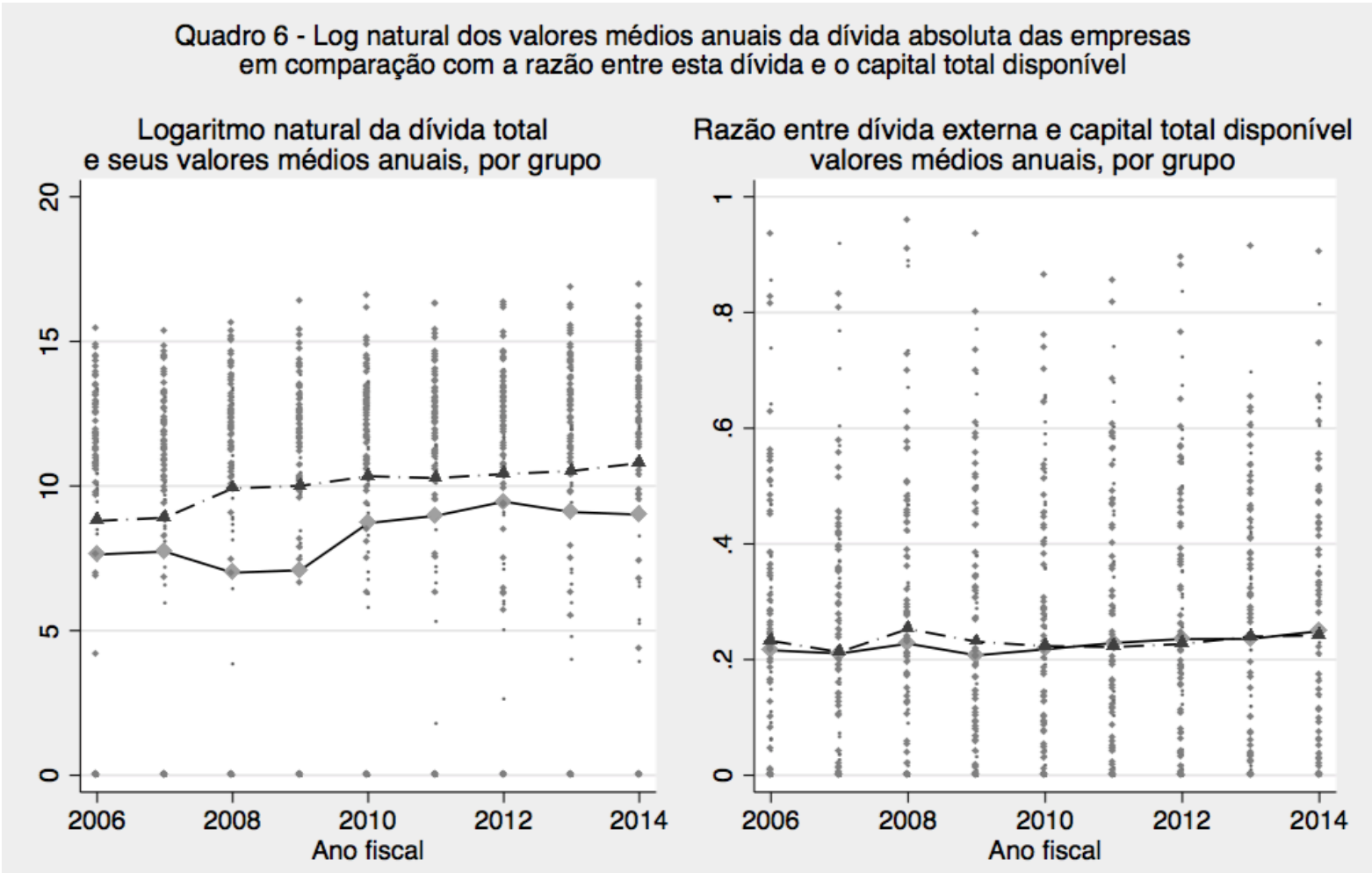

Notas: este quadro mostra o logaritmo natural da divida total das companhias e seus valores médios anuais à esquerda em comparação à razão entre a dívida externa e o capital total disponível para as empresas. A linha sólida representa o grupo controle. $\mathrm{N}=1,026$ observações, com 114 empresas. Fonte: autor.

No entanto, considerando o sinal dos coeficientes estimados nos modelos empregados para identificação dos efeitos da lei, o crescimento da razão dívida onerosa total por Ativo Total pode ter ocorrido de forma menos intensa nas empresas que possuem partes vinculadas estrangeiras, mas concluir que este fenômeno é causado pela referida lei requer investigações com amostras maiores e dados de operações de empréstimos intercompanhia ocorridas em 
ambos os grupos. O que se pode concluir da análise dos dados é que o endividamento das empresas, em ambos os grupos, apresentou tendência de crescimento no período, tanto em valores absolutos quanto em valores relativos ao Ativo Total, e que a lei não exerceu efeitos estatisticamente significantes sobre esta tendência, fazendo erigir questionamentos acerca da contribuição que a legislação realiza sobre a arrecadação tributária e acerca da sinergia que deveria existir entre a elaboração das peças legais tributárias e a disponibilidade de dados contábeis a investidores e quaisquer outros stakeholders interessados em conhecer as políticas de empresas com vínculos no exterior. Considerando a literatura correlata, é possível que os empréstimos intercompanhia estejam sendo substituídos por empréstimos externos que, provendo benefício tributário, tornam-se marginalmente mais interessantes do que os intercompanhia ora restritos e, ainda, fomentam o desenvolvimento do setor bancário com o pagamento de juros. 


\section{Seção VI - Conclusões}

Poucos estudos com dados brasileiros realizam investigações como esta, conduzida no formato de um estudo não aleatório com o emprego de dois métodos distintos que, respectivamente, consideram que ambos os grupos são afetados de maneira similar por políticas não observadas e comparam unidades semelhantes de forma a obter uma estimativa do efeito da lei. Em estudos observacionais como este, premissas tais como homogeneidade das unidades observacionais, independência do tratamento em relação a variáveis observadas, efeito constante do tratamento e aditividade, são substituídas por informação oriunda de dados obtidos nos períodos anteriores ao tratamento em questão de forma a se obter uma independência condicional ou, do conceito em língua inglesa, strong ignorability, (Holland, 1986; Holland \& Rubin, 1980). Foram fornecidos indícios de que as premissas para a viabilidade do emprego de ambos os métodos, respectivamente, paralelismo de tendências, comprovada por não significância da diferença observada entre os grupos a cada ano da série de tempo avaliada, e o balanceamento das observações pareadas por meio de matching, são plausíveis. Ainda, desconhecem-se fontes que forneçam os dados usados neste estudo, apresentando, à comunidade científica, resultados e informações inéditos no cenário brasileiro.

Os resultados encontrados apontam para o fato de que, aparentemente, a parcela do Ativo Total financiada por dívida onerosa estava, de qualquer forma, em ascensão nos dois grupos, mas o sinal negativo do efeito ora estimado acrescenta evidência parcial de que essa elevação pode ter sido menos intensa no grupo tratamento como efeito da lei. Ainda, não serem, os coeficientes, estatisticamente significantes torna necessário que se realizem investigações adicionais, com o intuito de descrever adequadamente a relação de causa e efeito entre essa legislação e os coeficientes observados, caso, apesar das evidências ora exibidas, ainda se suspeite da existência de tal efeito. Adicionalmente, caso a lei exerça de fato algum efeito para as empresas que possuem partes vinculadas estrangeiras, pode ser que este efeito não seja economicamente relevante para elas.

A principal contribuição deste estudo é a verificação da inexistência de efeitos da regra brasileira para subcapitalização sobre a estrutura de capital das empresas. A ausência de efeitos da lei, ou seja, a manutenção dos montantes relativos de dívida, se considerada a ideia da substituição do endividamento interno por externo, faz erigirem questões acerca do efeito contrário da norma, ou seja, a criação de incentivo às firmas a substituírem seus empréstimos intercompanhia por endividamento externo, cujos juros geram benefício tributário, não criando 
qualquer receita tributária incremental e, no entanto, gerando receitas de juros aos credores. $\mathrm{O}$ grau de substituibilidade entre essas duas fontes de financiamento constitui uma incógnita a ser investigada em estudos futuros, mas é possível que dependa, além de características das firmas, também dos mercados de capitais e situação econômica e do mercado de créditos do país. Outra evidência do efeito contrário da norma seria a elevação dos EICs das firmas que possuem baixos índices dessa operação. A formalização dos limites, permitindo fuga à caracterização como despesa não necessária, enquanto que, antes, tal operação poderia ser caracterizada como abuso de direito, proveria uma garantia de dedutibilidade, incentivando empresas a contratarem esse tipo de recurso e erodindo mais ainda a base tributária do IRPJ e CSLL. De fato, a eficácia da lei é apenas uma face dos efeitos que essa norma pode causar e apontar estes efeitos constitui contribuição secundária deste estudo. Além disso, a possibilidade e viabilidade da substituição de empréstimos intercompanhia por recursos externos pode tornar a lei ineficaz.

Finalmente, é possível que este estudo forneça um questionamento teórico à pesquisa sobre os determinantes de estrutura de capital. Nenhuma das principais teorias citadas na literatura sobre estrutura de capital, tais como tradeoff e pecking order, provê uma tratativa aos empréstimos intercompanhia, especialmente em ambientes de restrição de dedutibilidade. Pouco ainda se sabe sobre a relação entre regras de subcapitalização e decisão por estrutura ótima de capital ou sobre a preferência das empresas para obtenção de recursos, se EIC ou lucros retidos. Estes temas não são contemplados pela literatura corrente, especialmente no caso de companhias que não são listadas em bolsa de valores, mas responder tais questionamentos pode prover melhor entendimento da relação entre legislação e estrutura de capital.

Este estudo apresenta limitações relacionadas aos dados e à legislação que, paralelamente à norma específica avaliada, exerce influência sobre os resultados. Primeiro, a estimação do PSM poderia empregar, em adição àquelas que foram usadas, outras variáveis, principalmente as que se relacionam à composição e concentração de propriedade das empresas, ao conselho de administração, à atividade das empresas em todo o mundo, como quantidade de filiais ou de países em que elas atuam, e aos processos de auditoria das Demonstrações Financeiras, como turnover de auditores e contratação de grandes empresas. É possível que estes elementos estejam correlacionados com a existência de partes vinculadas estrangeiras e, portanto, teriam efeito no valor estimado do propensity score e, consequentemente, no pareamento dos invivíduos comparados e no efeito estimado da lei. Ainda, elementos discricionários tais como os mencionados podem estar correlacionados com o tratamento, demandando o uso de instrumentos para lidar com essas variáveis omitidas no modelo, caso existam razões para 
acreditar que exerçam influência sobre as premissas do método, por exemplo, sobre o paralelismo das tendências observadas antes da intervenção. Segundo, os dados foram extraídos, manualmente, das Demonstrações Financeiras, principalmente das Notas Explicativas, onde foram obtidas informações acerca da existência de partes vinculadas estrangeiras. Apenas a empresa responsável pela auditoria dessas informações pode garantir que elas refletem a realidade e, portanto, qualquer assimetria existente neste âmbito teve influência direta sobre os resultados deste estudo. E, terceiro, a norma contábil brasileira que prevê dados de transações com partes relacionadas nas Demonstrações Financeiras somente entrou em vigor no exercício fiscal de 2010. Enquanto que apenas algumas das empresas do grupo tratamento divulgam informações dessa natureza nos períodos anteriores, provavelmente em função de estarem sujeitas a normas de outros países ou terem ações em bolsa no Brasil, aquelas que não possuem partes vinculadas estrangeiras, bem como outras que possuem e não encontram-se obrigadas a tal por não serem listadas em bolsa antes de 2010 (ou optam por não evidenciar esta informação) não as apresentam, tornando impossível realizar inferências, a partir de séries temporais de informações publicamente disponíveis, sobre o efeito da lei no endividamento intercompanhia especificamente.

Considerando o aspecto recente da legislação e a indisponibilidade de dados ou dificuldade em obtê-los, é compreensível que não existam estudos realizados no Brasil que usem dados de empréstimos intercompanhia para explicar decisões organizacionais. De fato, inexistem bases de dados que organizem essas informações de forma prontamente disponível, bem como não existem estudos que relacionem os EICs às decisões que concernem estrutura de capital. Este estudo dá continuidade a um ramo de pesquisas que, no Brasil, ainda não foi explorado, exceto no campo teórico legal. Ainda, os métodos usados para identificar a relação investigada e descrever a interação de diferentes fatores que podem conduzir a mudanças na estrutura de capital de multinacionais são, em conjunto, uma contribuição procedimental à pesquisa em Contabilidade. Tanto a categoria de desenho de pesquisa experimento natural quanto a aplicação do estimador de diferenças em diferenças constituem elementos relativamente recentes na pesquisa contábil e, em especial, na pesquisa contábil brasileira.

Uma limitação adicional deste estudo se refere à premissa da substituição do financiamento interno por financiamento externo quando os limites estabelecidos pela legislação forem atingidos. Embora seja uma premissa racional, dado que os gestores deverão preferir pagar juros dedutíveis ao invés de pagar juros não dedutíveis, a contratação de recursos externos é determinada, também, por fatores institucionais, como, apenas para listar alguns, o 
desenvolvimento do mercado de capitais do país e a legislação de proteção a credores e devedores (Noe, 1999; Shleifer \& Wolfenzon, 2002), além da disponibilidade de garantias e grau de endividamento prévio. Dependendo do ambiente legal, no que tange às possibilidades e habilidades de negociação com credores, podem existir menos incentivos para evitar falências, elevando as taxas de juros do mercado (Desai et al., 2004). Este estudo não contempla análises institucionais do mercado brasileiro, ou mesmo elementos macroeconômicos que podem ter efeitos sobre as decisões das companhias, principalmente em função da premissa de que estes elementos afetam as empresas de ambos os grupos com a mesma intensidade. No entanto, tal premissa poderia, com amostras maiores e análises diversas, ser provada falsa.

Ainda, o estudo foi realizado sob a expectativa de que parcela relevante da dívida intercompanhia que financia as operações de empresas brasileiras possuidoras de partes vinculadas estrangeiras existe como resultado de decisões que visam à redução da carga tributária sobre a renda dessas empresas. Esta expectativa parte da exposição de motivos da lei e não considera que o uso de recursos desta natureza pode resultar de fatos ou políticas não relacionadas a planejamento tributário, com o objetivo de produzir efeitos diversos da diminuição dos tributos sobre o lucro. Embora tenha visão limitada no que se refere às razões pelas quais as empresas se endividam com seu próprio grupo empresarial, esta norma apresenta pelo menos uma inovação em relação a normas praticadas em outros países: considera, para fins de cálculo do limite de endividamento que permite a dedução dos juros, a parcela que a empresa cedente dos recursos possui no Patrimônio Líquido da parte que os recebe. No entanto, apesar da criatividade, a lei falha (ou tem o propósito de) ao não considerar as evidências empíricas de que regulamentação sobre a dedutibilidade de juros dessa natureza cria incentivos para que sejam substituídos os empréstimos intercompanhia por empréstimos oriundos de instituições financeiras. O efeito final é que, apenas com a alteração da natureza da dívida que financia a operação, nada muda na carga tributária da empresa, tendo, a lei, efeito nulo sobre a arrecadação, além de dificultar que as organizações atinjam objetivos estratégicos que podem ter, como requisitos, a participação de partes vinculadas no endividamento de filiais em outros países. O efeito desta visão limitada sobre as razões pelas quais companhias mantém empréstimos internos encontra-se refletido neste estudo, que não inclui variáveis que poderiam identificar razões estratégicas para a manutenção destes recursos. Por outro lado, mesmo portando tais limitações, caso as barreiras institucionais para obtenção de empréstimos externos sejam de difícil transposição, o efeito observado poderia ser a redução da alavancagem total. 
Obviamente, os achados deste estudo encontram-se delimitados à amostra empregada. $\mathrm{O}$ fato de que apenas empresas que possuem observações anuais durante todo o período empregado e que não tenham alterado seu status de possuir partes vinculadas estrangeiras constarem no estudo pode contribuir para a existência de viés de seleção. Portanto, generalizações destes resultados podem não ser adequadas a situações em que, por exemplo, alterações frequentes nos quadros societários incluem pessoas estrangeiras ou, ainda, objetivos de planejamento tributário. De fato, esta situação constitui um motivo adicional de pesquisas futuras, posto que, até o presente momento, a literatura não apresenta estudos que tenham investigado a relação entre planejamento tributário e dinâmica internacional da composição societária das organizações.

Finalmente, enquanto as companhias buscam determinar a parcela ótima de dívida de forma a maximizar o valor da empresa, os governos buscam elevar sua receita tributária, configurando um jogo que, por sua vez, poderia constituir tema de estudos futuros. Portanto, em um mercado em que não existem maneiras de garantir que estes objetivos convirjam naturalmente para o mesmo destino, governos emitirão normas para impedir a queda na arrecadação ao mesmo tempo em que a administração das empresas buscará encontrar novas maneiras de reduzir o pagamento de tributos sobre o lucro, e a internacionalização é uma delas, tornando possível, às empresas, minimizar os pagamentos de tributos por meio da adequação de suas estruturas de capital às diferenças entre alíquotas e normas tributárias vigentes em diferentes países.

Por outro lado, embora a literatura corrente acerca do tema "estrutura de capital" seja extensa e abrangente, incluindo o termo "risco" em diferentes abordagens e estabelecendo relações de associação e causalidade entre um número de elementos organizacionais, o papel desempenhado por recursos de origem intercompanhia nessas relações, em especial aqueles originários de outros países, tem sido alvo de raras investigações. Perguntas como "qual a influência que recursos desta natureza exercem sobre o risco de falência?", "qual é a relação entre a quantidade e natureza dos contratos que estabelecem o uso destes recursos e as empresas que os empregam?” ou “em que grau a composição societária ou concentração de propriedade das organizações determinam o uso dado a estes recursos?" ainda não foram realizadas, embora suas respostas possam contribuir para uma melhor elaboração de normas que tenham os mesmos objetivos da lei avaliada neste estudo.

Já em suas origens, estudos teóricos e empíricos sobre determinantes de estrutura de capital admitem a subjetividade das funções de utilidade do uso de recursos que não os criados 
internamente: os lucros. No entanto, mesmo em face das constatações de que tributos sobre o lucro, elemento cujo processo de apuração concede determinada liberdade à administração para reduzir perdas, modificam as regras da relação entre estrutura de capital e valor de empresa, a existência dos empréstimos intercompanhia tem sido, na falta de palavra melhor, negligenciada quando se trata de contribuir para o aumento da abrangência do entendimento dessa relação entre tributos e financiamento organizacional. De fato, se MM concluem que ganhos após os tributos, que incluem benefícios tributários de dívida, devem ser descontados a uma taxa favorável em relação àquela a que se descontam fluxos de caixa antes de tributos, que se encontram sujeitos a risco maior, não teria, um contrato de dívida com partes vinculadas, função diferenciada na geração de benefícios tributários, posto que agrega elementos de risco distintos daqueles observados em contratos com terceiros? Ainda, teriam os empréstimos intercompanhia alguma influência sobre o fato de que, mesmo existindo benefícios tributários em se endividarem, as empresas não se endividam até o máximo de suas necessidades financeiras? De fato, as normas antielisivas, aquelas que visam a mitigar o uso intensivo de financiamento intercompanhia com fins a deduzir pagamentos da base de cálculo dos tributos sobre o lucro, surgem com o intuito de evitar este "endividamento total" em detrimento da existência de Patrimônio Líquido, o que poderia gerar uma nova pergunta a ser respondida em pesquisas futuras: se fosse legal e tivesse o mesmo custo financeiro do empréstimo bancário, haveria limites para empréstimos intercompanhia? É possível que, em não existindo limites para dedução dos benefícios obtidos com recursos oriundos do mesmo grupo empresarial, a pergunta de Miller (1977) sobre a razão de as empresas não se endividarem até o limite de suas necessidades financeiras talvez não se aplicasse no âmbito de grupos empresariais ou, no mínimo, seria reformulada para incluir outros elementos relacionados aos mercados financeiros, tais como a assimetria informacional existente entre indivíduos, bancos e empresas pertencentes ao mesmo grupo da contratante das dívidas. A área de pesquisa que investiga os mercados internos de capitais, embora se encontre já abrangente em termos de investigação da eficiência da alocação dos recursos, precisa ainda esclarecer o papel que recursos internos desempenham em função de sua influência nos tributos sobre o lucro.

Quando se analisam as contas do Balanço de Pagamentos brasileiro, a importância destes estudos fica mais evidente. Enquanto que os valores de ingresso na forma de empréstimos intercompanhia totalizaram 15,2 bilhões de dólares no ano de 2006, esta cifra alcançou a soma de 63,8 bilhões de dólares em 2014, considerando as operações entre matrizes e filiais em ambos os sentidos. Estudos futuros devem investigar o valor total do potencial 
benefício tributário envolvido nestas somas. Para fins de comparação, considerando que o orçamento do Ministério da Saúde brasileiro para 2014 foi de 106 bilhões de reais e que o do Ministério da Educação foi de 95 bilhões de reais (Brasil, 2014), é possível perceber que os recursos oriundos do exterior e aplicados no Brasil podem representar uma receita tributária importante para a nação. Embora alguns estudos descrevam formas de estimar o que se poderia chamar de "quantidade esperada" de recursos intercompanhia na forma de dívida que ingressam em um dado país (Grubert \& Mutti, 1991), ainda é necessário avançar muito no que diz respeito aos benefícios esperados da entradas destes recursos e aos efeitos que uma possível erosão da base tributária representa para a economia de um país. 


\section{Seção VII - Referências}

Aghion, P., \& Bolton, P. (1989). The financial structure of the firm and the problem of control. European Economic Review. https://doi.org/10.1016/0014-2921(89)90105-0

Aghion, P., \& Bolton, P. (1992). An incomplete contract approach to financial contracting. Review of Economic Studies, 59(3), 473-494. https://doi.org/Doi 10.2307/2297860

Albanez, T., Valle, M. R. do, \& Corrar, L. J. (2012). Fatores institucionais e assimetria informacional: influência na estrutura de capital de empresas brasileiras. Revista de Administração Mackenzie, 13(2), 76-105.

Alfaro, L., Chanda, A., Kalemli-Ozcan, S., \& Sayek, S. (2004). FDI and economic growth: The role of local financial markets. Journal of International Economics, 64(1), 89-112. https://doi.org/10.1016/S0022-1996(03)00081-3

Allen, D. E. (2000). Spare Debt Capacity: Company Practices in Australia, Britain and Japan. Australian Journal of Management, 25(3).

Almfraji, M. A., \& Almsafir, M. K. (2014). Foreign Direct Investment and Economic Growth Literature Review from 1994 to 2012. Procedia - Social and Behavioral Sciences, 129(129), 206-213. https://doi.org/10.1016/j.sbspro.2014.03.668

Amin, M., Khalid, M., \& Yao, L. (2014). Economic Growth and Foreign Direct Investment Inflows : The Case of Qatar. Procedia - Social and Behavioral Sciences, 109, 1040-1045. https://doi.org/10.1016/j.sbspro.2013.12.586

Ang, T. C. (2015). Are Firms with Negative Book Equity in Financial Distress? Are Firms with Negative Book Equity in Financial Distress? Review of Pacific Basin Financial Markets and Policies, 18(3). https://doi.org/10.1142/S0219091515500162

Angrist, J. D., \& Pischke, J.-S. (2009). Mostly Harmless Econometrics: An Emiricist's Companion. (P. U. Press, Ed.). Princeton: Princeton University Press.

Balasubramanyam, V. N., Salisu, M., \& Sapsford, D. (1996). Foreign Direct Investment and Growth in EP and is Countries. The Economic Journal, 106, 92-105.

Basu, D., \& Rubin, D. B. (1980). Randomization Analysis of Experimental Data: The Fisher Randomization Test. Journal of the American Statistical Association, 75(371), 575-582. https://doi.org/10.2307/2287648

Bertrand, M., Duflo, E., \& Mullainathan, S. (2004). How much should we trust differences-in 
differences estimates? Quarterly Journal of Economics, 119(1), 249-275. https://doi.org/10.1162/003355304772839588

Blomstrom, M., Lipsey, R. E., \& Zejan, M. (1992). What Explains Developing Country Growth? National Bureau of Economic Research Working Paper Series. https://doi.org/10.3386/w4132

Blouin, J., \& Huizinga, H. (2014). Thin Capitalization Rules and Multinational Firm Capital Structure (No. WP/14/12). IMF Working Paper. https://doi.org/10.2778/32784

Borensztein, E., Gregorio, J. De, \& Lee, J.-W. (1998). How does foreign direct investment affect economic growth. Journal of International Economics, 45(1), 115-135. https://doi.org/10.1016/S0022-1996(97)00033-0

Boyd, J. H., \& Smith, B. D. (1992). Intermediation and the equilibrium allocation of investment capital. Implications for economic development. Journal of Monetary Economics, 30(3), 409-432. https://doi.org/10.1016/0304-3932(92)90004-L

Brasil. Lei $n^{\circ} 4.131$, de 3 de setembro de 1962 (1962).

Brasil. Decreto $\mathrm{n}^{0}$ 55.762, de 17 de fevereiro de 1965 (1965).

Brasil. Decreto n ${ }^{\circ} 1.598$ de 26 de dezembro de 1977 (1977).

Brasil. Lei n 7.689 de 15 de dezembro de 1988 (1988).

Brasil. Lei n ${ }^{\circ} 9.430$ de 27 de dezembro de 1996 (1996).

Brasil. Lei n ${ }^{\circ}$ 9.532, de 10 de dezembro de 1997 (1997).

Brasil. (2010). Lei n ${ }^{\circ} 12.249$, de 11 de junho de 2010.

Brasil. (2011). Exposição de Motivos Interministerial 180/2009 MF/MDIC.

Brasil. Lei n ${ }^{\circ} 12.715$ de 17 de setembro de 2012 (2012).

Brasil. Medida Provisória n 563 de 3 de abril de 2012 (2012).

Brasil. (2014). Lei 12.952 de 20 de janeiro de 2014. Diário Oficial Da União, pp. 1-2280.

Brasil, B. C. do. Resolução n 3.844 de 23 de março de 2010 (2010).

Brasil, B. C. do. PEDD Padrão Especial de Disseminação de Dados DÍVIDA EXTERNA Dados sobre o Provedor da Categoria Descrição (2011). Retrieved from http://www.bcb.gov.br/sddsp/divexterna_p.htm 
Brasil, B. C. do. Circular n 3.689 de 16 de dezembro de 2014 (2013).

Brasil, R. F. do. (2011). Instrução Normativa 1.154 de 12 de maio de 2011, 1-12.

Brito, R. D., Lima, M. R., \& Silva, J. C. (2009). O crescimento da remuneração direta aos acionistas no Brasil: economia de impostos ou mudança de características das firmas? Brazilian Business Review, 6(1), 62-81.

Büettner, T., Overesch, M., Schreiber, U., \& Wamser, G. (2012). The impact of thincapitalization rules on the capital structure of multinational firms. Journal of Public Economics, 96(11-12), 930-938. https://doi.org/10.1016/j.jpubeco.2012.06.008

Buettner, T., Overesch, M., \& Wamser, G. (2015). Restricted Interest Deductibility and Multinationals ’ Use of Internal Debt Finance (Working Paper). Tübingen.

Büettner, T., \& Wamser, G. (2013). Internal debt and multinational profit shifting: empirical evidence from firm-level panel data. National Tax Journal, 66(March), 63-96.

Carcanholo, M. D. (2002). Abertura Externa e Liberalização Financeira: Impactos sobre o Crescimento e Distribuição no Brasil nos Anos 90. Universidade Federal do Rio de Janeiro.

Carkovic, M. (2005). Does foreign direct investment accelerate economic growth? In I don't know yet (pp. 195-220).

Cheung, D. K. C. (2012). The Law and Practice of Thin Capitalization Rules in China. International Tax Journal, (November-December), 53-59.

Chowdhry, B., \& Coval, J. D. (1998). Internal financing of multinational subsidiaries: Debt vs. equity. Journal of Corporate Finance1, 4, 87-106.

Chu, H. (2012). Optimal Thin Capitalisation Rule in a Simple Endogenous Growth Model with Tax Havens. Australian Economic Papers, 51(3), 123-133. https://doi.org/10.1111/j.1467-8454.2012.00427.x

Clausing, K. A. (2009). Multinational Firm Tax Avoidance and Tax Policy. National Tax Journal, LXII(4), 703-725.

Colombo, J. A., \& Terra, P. R. S. (2012). Juros Sobre o Capital Próprio, Estrutura de Propriedade e Destruição de Valor: Evidências no Brasil. In Anais da Associação Nacional de Pós-Graduação em Economia.

CPC, C. de P. C. Pronunciamento Técnico CPC 05 (2010). Retrieved from 
http://www.cpc.org.br/CPC/Documentos-

Emitidos/Pronunciamentos/Pronunciamento?Id=36

DeAngelo, H., \& Masulis, R. (1980). Optimal capital structure under corporate and personal taxation. Journal of Financial Economics. Retrieved from http://www.sciencedirect.com/science/article/pii/0304405X80900197

Desai, M. A., \& Dharmapala, D. (2015). Interest Deductions in a Multijurisdictional World, 68(June 2012). Retrieved from http://ssrn.com/abstract=2603470\%5Cnhttp://www.law.uchicago.edu/Lawecon/index.ht $\mathrm{ml}$

Desai, M. A., Foley, C. F., \& Hines Jr., J. R. (2004). A Multinational Perspective on Capital Structure Choice and Internal Capital Markets. The Journal of Finance, LIX(6).

Dichev, I. (1998). Is the risk of bankruptcy a systematic risk? Journal of Finance, 53, 11311147.

Doidge, C., \& Dyck, A. (2015). Taxes and Corporate Policies: Evidence from a Quasi Natural Experiment. The Journal of Finance, 70(1), 45-89. https://doi.org/10.1111/jofi.12101

Dritsaki, C., \& Stiakakis, E. (2014). Foreign Direct Investments, Exports, and Economic Growth in Croatia: A Time Series Analysis. Procedia Economics and Finance, 14(1992), 181-190. https://doi.org/10.1016/S2212-5671(14)00701-1

Egger, P., Eggert, W., Keuschnigg, C., \& Winner, H. (2010). Corporate taxation, debt financing and foreign-plant ownership. European Economic Review, 54(1), 96-107. https://doi.org/10.1016/j.euroecorev.2009.06.007

Egger, P., Keuschnigg, C., Merlo, V., \& Wamser, G. (2014). Corporate Taxes and Internal Borrowing within Multinational Firms. American Economic Journal: Economic Policy, 6(2), 54-93. https://doi.org/10.1257/pol.6.2.54

Elliffe, C. (2013). Trans-tasman thin capitalisation rules and treaties : implications for New Zealand and Australia on tighter thin capitalisation ratios. Australian Tax Forum, 18(4), 605-641.

Fama, E. F., \& French, K. R. (1999). The Corporate Cost of Capital and the Return on Corporate Investment. The Journal of Finance, 54(6), 1939-1967. https://doi.org/10.1111/00221082.00178 
Fama, E., \& French, K. R. (1992). The cross-section of expected stock returns. Journal of Finance, 47, 427-465.

Farhi, M., \& Prates, D. (2006). A Nova Dimensão da Vulnerabilidade Externa. Política Econômica Em Foco, 1-6.

Farrar, J., \& Mawani, A. (2008). Debt-Equity Limitations in Thin Capitalization Rules: Canadian Evidence. In Canadian Academic Accounting Association. Retrieved from https://ssrn.com/abstract=1080639

Feeny, S., Iamsiraroj, S., \& McGillivray, M. (2014). Growth and Foreign Direct Investment in the Pacific Island countries. Economic Modelling, 37, 332-339. https://doi.org/10.1016/j.econmod.2013.11.018

Flath, D., \& Knoeber, C. R. (1980). Taxes , Failure Costs , and Optimal Industry Capital Structure : An Empirical Test, $X X X V(1), 99-118$.

Forte, D., Barros, L. A., \& Nakamura, W. T. (2013). Determinants of the Capital Structure of Small and Medium Sized Brazilian Enterprises. Brazilian Administration Review, 10(3), $347-369$.

Futema, M. S., Fernando, L., Basso, C., \& Kayo, E. K. (2009). Estrutura de capital, dividendos e juros sobre o capital próprio : testes no Brasil. Revista Contabilidade E Finanças, 20(49), $44-62$.

Garrido, M. M., Kelley, A. S., Paris, J., Roza, K., Meier, D. E., Morrison, R. S., \& Aldridge, M. D. (2014). Methods for Constructing and Assessing Propensity Scores. Health Research and Educational Trust, 49(5), 1701-1720. https://doi.org/10.1111/14756773.12182

Gatzer, S., Hoang, D., \& Ruckes, M. (2014). Internal capital markets and diversified firms: Theory and practice (Working Paper Series in Economics).

Gertner, R. H., Scharfstein, D. S., \& Stein, J. C. (1994). Internal Versus External Capital Markets. The Quarterly Journal of Economics, 109(4), 1211-1230. https://doi.org/10.2307/2118361

Gopalan, R., Nanda, V., \& Seru, A. (2007). Affiliated firms and financial support: Evidence from Indian business groups. Journal of Financial Economics, 86(3), 759-795. https://doi.org/10.1016/j.jfineco.2006.09.008 
Gordon, R. H., \& MacKie-Mason, J. K. (1990). Effects of the Tax Reform Act of 1986 on Corporate Financial Policy and Organizational Form (No. 3222). Do Taxes Matter? The Impact of the Tax Reform Act of 1986. Retrieved from http://ideas.repec.org/p/nbr/nberwo/3222.html

Göritzer, A. (2012). Thin Capitalization Rule vs Interest Barrier (Universität Wien Working Papers. No. Working Paper nn. 2012-3). Vienna.

Graham, J. R. (2013). Do Taxes Affect Corporate Decisions? A Review. In Handbook of the Economics of Finance (Vol. 2, pp. 123-210). Elsevier B.V. https://doi.org/10.1016/B9780-44-453594-8.00003-3

Grubert, H. (2003). Intangible Income, Intercompany Transactions, Income Shifting, and the Choice of Location. National Tax Journal, 56(1), 221-242. Retrieved from http://search.ebscohost.com/login.aspx?direct=true $\& d b=$ buh $\& A N=9632024 \&$ site $=$ ehostlive

Grubert, H., \& Mutti, J. (1991). Taxes, Tariffs and Tranfers Pricing in Multinational Corporate Decisoin Making. The Review of Economics and Statistics, 73(2), 285-293.

Hammer, C., \& Kvarberg, M. (2015). Do Thin-Capitalization Rules Affect Capital Structure Decisions? Evidence from Norwegian Multinationals.

Handouyahia, A., Haddad, T., \& Eaton, F. (2013). Kernel Matching versus Inverse Probability Weighting: A Comparative Study. International Journal of Science, Engineering and Technology, 7(8), 1218-1233.

Harris, M., \& Raviv, A. (1991). The Theory of Capital Structure. The Journal of Finance, 46(1), 297-355. https://doi.org/10.1111/j.1540-6261.1991.tb03753.x

Haufler, A., \& Runkel, M. (2008). Multinationals' Capital Structures, Thin Capitalization Rules, and Corporate Tax Competition. CESIFO Venice Summer Institute.

Hauptman, L., \& Tič, S. (2014). Capital Structure and Thin-capitalization Rule: Case study of parent companies in Slovenia. Our Economy, Journal of Contemporary Issues in Economics and Business, 60(1-2), 37-46. https://doi.org/10.7549/ourecon.2014.1-2.04

Heckman, J. J., Ichimura, H., \& Todd, P. (1998). Matching As An Economic Evaluation Estimator. Review of Economic Studies, 65(2), 261-294. https://doi.org/10.1111/1467937X.00044 
Hirano, K., Imbiens, G. W., \& Geert, R. (2003). Efficient Estimation of Average Treatment Effects Using the Estimated Propensity Score. Econometrica, 71(4), 1161-1189. https://doi.org/10.1111/1468-0262.00442

Holland, P. W. (1986). Statistics and Casual Inference. Journal of the American Statistical Association. https://doi.org/10.1080/01621459.1986.10478354

Holland, P. W., \& Rubin, D. B. (1980). Causal Inference in Prospective and Retrospective Studies. Princeton.

Jan, C.-L., \& Ou, J. (2012). Negative book value firms and their valuation. Accounting Horizons, 26, 91-110.

Jensen, M. C. (1986). Agency Costs of Free Cash Flow, Corporate Finance, and Takeovers. The American Economic Review, 76(2), 323-329. https://doi.org/10.2139/ssrn.99580

Jones, M. C., Cline, M., \& Ryan, S. (2006). Exploring knowledge sharing in ERP implementation: an organizational culture framework. Decision Support Systems, 41(2), 411-434. https://doi.org/10.1016/j.dss.2004.06.017

Khandker, S. R., Koolwal, G. B., \& Samad, H. a. (2010). Handbook on Impact Evaluation: Quantitative Methods and Practices. Learning. https://doi.org/10.1596/978-0-8213-80284

Kraus, A., \& Litzenberger, R. H. (1973). A state-preference model of optimal financial leverage. Journal of Finance, 28(4), 911-922.

Lamont, O. (1997). Cash Flow and Investment: Evidence from Internal Capital Markets. The Journal of Finance, 52(1), 83-109.

Lessambo, F. (2009). Taxation of International Business Transaction. Bloomington: iUniverse.

Leuven, E., \& Sianesi, B. (2003). psmatch2: Stata module to perform full Mahalanobis and propensity score matching, common support graphing, and covariate imbalance testing. Stata Journal.

Li, B., Lajbcygier, P., Guo, S., \& Xiaoying, C. (2007). Default risk, return and negative book equity stock.

Li, X., \& Liu, X. (2005). Foreign Direct Investment and economic growth: An increasingly endogenous relationship. World Development, 33(3), 393-407. https://doi.org/10.1016/j.worlddev.2004.11.001 
Linden, A. (2015). Conducting interrupted time series analysis for single and multiple group comparisons. Stata Journal, 15(2), 480-500. https://doi.org/10.1093/ije/dyt092

Linden, A., \& Adams, J. L. (2011). Applying a propensity score-based weighting model to interrupted time series data: Improving causal inference in programme evaluation. Journal of Evaluation in Clinical Practice, 17(6), 1231-1238. https://doi.org/10.1111/j.13652753.2010.01504.x

Massbaum, A., \& Sureth, C. (2009). Thin Capitalization Rules and Entrepreneurial Capital Structure Decisions. Business Research, 2(2), 147-169.

Meyer, B. D. (1995). Natural and Quasi-Experiments in Economics. Journal of Business and Economics Statistics, 13(2), 151-161.

Miller, M. H. (1977). Debt and Taxes. The Journal of Finance, 32(2).

Mintz, J., \& Smart, M. (2004). Income shifting, investment, and tax competition: Theory and evidence from provincial taxation in Canada. Journal of Public Economics, 88(6), 1149 1168. https://doi.org/10.1016/S0047-2727(03)00060-4

Modigliani, F., \& Miller, M. H. (1958). The Cost of Capital, Corporation Finance and the Theory of Investment. The American Economic Review, 48(3), 261-297.

Modigliani, F., \& Miller, M. H. (1963). Corporate income taxes and the cost of capital: a correction. The American Economic Review, 53(3), 433-443.

Moraes, R. L. De. (2014). O Propósito Negocial Como Elemento Essencial Para O Planejamento Tributário Na Era Da Sustentabilidade. AREL FAAr, 2(2), 41-68.

Myers, S. C. (1977). Determinants of corporate borrowing. Journal of Financial Economics, 5(2), 147-175. https://doi.org/10.1016/0304-405X(77)90015-0

Myers, S. C. (1984). The Capital Structure Puzzle. The Journal of Finance, 39(3), 575. https://doi.org/10.2307/2327916

Myers, S. C., \& Majluf, N. S. (1984). Corporate financing and investment decisions when firms have information that investors do not have. Journal of Financial Economics, 13(2), 187221. https://doi.org/10.1016/0304-405X(84)90023-0

Nichols, A. (2007). Causal inference with observational data. The Stata Journal, 7(4), 507-541.

Nichols, A. (2008). Erratum and discussion of propensity-score reweighting. Stata Journal, 8(4), 532-539. https://doi.org/The Stata Journal 
Noe, T. H. (1999). Creditor Rights and Multinational Capital Structure.

OECD. (2012). Thin Capitalization Legislation. Zhurnal Eksperimental'noi i Teoreticheskoi Fiziki.

Overesch, M. (2009). The Effects of Multinationals' Profit Shifting Activities on Real Investments. National Tax Journal, LXIl(1).

Overesch, M., \& Wamser, G. (2010a). Corporate tax planning and thin-capitalization rules: evidence from a quasi-experiment. Applied Economics, 42(5), 563-573. https://doi.org/10.1080/00036840701704477

Overesch, M., \& Wamser, G. (2010b). The effects of company taxation in EU accession countries on German FDI. Economics of Transition, 18(3), 429-457. https://doi.org/10.1111/j.1468-0351.2009.00385.x

Pedrosa Junior, M. (2014). Planejamento Tributário Internacional com Subcapitalização : O conceito de renda e as regras brasileiras de Subcapitalização. In Congresso Internacional de Direito Tributário (pp. 1-20). Associação Brasileira de Direito Tributário.

Pfaffermayr, M., Stöckl, M., \& Winner, H. (2013). Capital Structure, Corporate Taxation and Firm Age. Fiscal Studies, 34(1), 109-135.

Pilati, R., \& Laros, J. A. (2007). Modelos de equações estruturais em psicologia: conceitos e aplicações. Psicologia: Teoria E Pesquisa, 23(2), 205-216. https://doi.org/10.1590/S0102-37722007000200011

Pohlmann, M. C., \& Iudícibus, S. De. (2010). Relação entre a tributação do lucro e a estrutura de capital das grandes empresas no Brasil. Revista Contabilidade E Finanças, 21(53), 125.

Prezas, A. P. (2009). Internal capital markets, empire building, and capital structure. Journal of Economics and Business, 61(3), 173-188. https://doi.org/10.1016/j.jeconbus.2008.09.001

Rajan, R. G., \& Zingales, L. (1995). What Do We Know About Capital Structure - Some Evidence From International Data. The Journal of Finance, 50(5), 1421-1460. https://doi.org/10.2307/2329322

Ramb, F., \& Weichenrieder, A. J. (2005). Taxes and the financial structure of German inward FDI. Review of World Economics, 141(4), 670-692. https://doi.org/10.1007/s10290-0050051-7 
Romer, P. (1993). Idea gaps and object gaps in economic development. Journal of Monetary Economics, 32(3), 543-573. https://doi.org/10.1016/0304-3932(93)90029-F

Rosenbaum, P. R., \& Rubin, D. B. (1983). The central role of the propensity score in observational studies for causal effects. Biometrika, 70(1), 41-55. https://doi.org/10.1093/biomet/70.1.41

Rubin, D. B. (1974). Estimating causal effects of treatments in randomized and nonrandomized studies. Journal of Educational Psychology, 66(5), 688-701.

Schindler, D., \& Schjelderup, G. (2012). Debt shifting and ownership structure. European Economic Review, 56(4), 635-647. https://doi.org/10.1016/j.euroecorev.2012.02.015

Schneller, M. I. (1980). Taxes and the Optimal Capital Structure of the Firm. The Journal of Finance, $X X X V(1), 119-128$.

Schreiber, U., Overesch, M., Büettner, T., \& Wamser, G. (2006). The Impact of ThinCapitalization Rules on Multinationals? Financing and Investment Decisions (ZEW Discussion Papers No. 06-68).

Scott, J. H. (1977). Bankruptcy, Secured Debt and Optimal Capital Structure. The Journal of Finance, 32(2), 1013. https://doi.org/10.2307/2329297

Seida, J. A., \& Wempe, W. F. (2004). Effective Tax Rate Changes and Earnings Stripping Following Corporate Inversion. National Tax Journal, 57(4), 805-828.

Shadish, W.R., Cook, T.D., \& Campbell, D. T. (2002). Experimental and Quasi-Experimental Designs. In Experimental and Quasi-Experimental Designs for Generalized Causal Inference. (pp. 171-206). https://doi.org/10.1093/obo/9780195389678-0053

Shleifer, A., \& Wolfenzon, D. (2002). Investor protection and equity markets. Journal of Financial Economics, 66(1), 3-27. https://doi.org/10.1016/S0304-405X(02)00149-6

Stein, J. C. (1997). Internal Capital Markets and the Competition for Corporate Resources. The Journal of Finance, 52(1), 111-133.

Stuart, E. A. (2010). Matching methods for causal inference: A review and a look forward. Statistical Science, 25(1), 1-21. https://doi.org/10.1214/09-STS313.Matching

Stuart, E. A., Duckworth, K., Simmons, J., \& Barry, C. L. (2014). Using propensity scores in difference-in-differences models to estimate the effects of a policy change. Health Serv Outcomes Res Methodol, 14(4), 166-182. https://doi.org/10.1007/s10742-014-0123- 


\section{z.Using}

Taggart, R. A. (1980). Taxes and Corporate Capital Structure in an Incomplete Market. The Journal of Finance, $X X X V(3), 645-660$.

Titman, S., \& Wessels, R. (1988). The determinants of capital structure choice. The Journal of Finance, XLIII(1), 1-19. https://doi.org/10.1108/ARLA-01-2014-0007

Veiga, A. Z., Imbrosio, D. D. A., \& Ferreira, L. F. (2007). Remuneração aos acionistas e os reflexos tributários no resultado da empresa: um estudo de caso em uma instituição financeira. Revista Catarinense Da Ciência Contábil, 17-32. https://doi.org/101693022377662

Vicentini, M. F. (2014). Subcapitalização no direito tributário brasileiro. Universidade de São Paulo.

Wamser, G. (2014). The Impact of Thin-Capitalization Rules on External Debt Usage - A Propensity Score Matching Approach. Oxford Bulletin of Economics and Statistics, 76(5), 764-781. https://doi.org/10.1111/obes. 12040

Webber, S. (2010a). Thin Capitalization and Interest Deduction Regulations (No. Discussion Paper No. 8.2010). CORIT Academic.

Webber, S. (2010b). Thin capitalization and interest deduction rules: a worldwide survey. Tax Notes International, 60(9), 683-708.

Wooldridge, J. M. (2011). Ferramentas Matemáticas Básicas. Introdução À Econometria: Uma Abordagem Moderna, 1-20.

Zhang, Y., Hom, H., \& Kong, H. (2014). The Efficiency of Internal Capital Markets and the Quality of Internal Accounting Information, (548713). 


\section{Glossário}

B3 - antiga BM\&FBOVESPA. Bolsa de valores brasileira.

BCB - Banco Central do Brasil

CPC - Comitê de Pronunciamentos Contábeis

CVM - Comissão de Valores Mobiliários

CSLL - Contribuição Social Sobre o Lucro Líquido

DD - Estimados de diferenças-em-diferenças

DDL - Distribuição Disfarçada de Lucros

EIC - Empréstimo Intercompanhia

IBD - Investimento Brasileiro Direto

IED - Investimento Estrangeiro Direto

Dívida intercompanhia - empréstimos obtidos com partes relacionadas

IR - Imposto de Renda

IRPJ - Imposto de Renda Pessoa Jurídica

JSCP - Juros Sobre o Capital Próprio

MM - Modigliani e Miller, 1958

MM' - Modigliani e Miller, 1963.

PSM - Propensity Score Matching

RIR - Regulamento do Imposto de Renda

Subcapitalização - processo por meio do qual uma entidade é financiada por quantidades significativamente maiores de dívidas do que de capital. Em geral, as dívidas têm origem intercompanhia.

TJLP - Taxa de Juros de Longo Prazo 
Anexo A - Nota de auditoria independente.

6. Conforme descrito na Nota 5 às demonstrações financeiras, a Companhia mantém relações e transações em montantes significativos com sua controladora e companhias associadas. Conseqüentemente, os resultados de suas operações podem ser diferentes daqueles que seriam obtidos de transações efetuadas apenas com partes não relacionadas.

$$
\text { São Paulo, } 30 \text { de abril de } 2009
$$

PRICEWATEROUSECOPERS TO

Auditores Independentes Valdir Renato Coscodai

CRC 2SP000160/O-5

Contador CRC 1SP165875/O-6 


\section{Anexo B - Lista das empresas usadas no estudo.}

\begin{tabular}{|c|c|c|c|}
\hline Empresa & Atividade & Empresa & Atividade \\
\hline 524 Participações S. A. & Holding & Iochpe Maxion S. A. & Indústria e comércio \\
\hline AES Elpa S. A. & Participação & Itautec & Participação \\
\hline Siderúrgica J.L. Aliperti S. A. & Fabricação de peças & Indústrias J. B. Duarte S. A. & Indústria e comércio \\
\hline ALL - America Latina Logística Malha Sul S. A. & Prestação de serviços & JBS S.A. & Indústria \\
\hline Alunorte Alumina do Norte do Brasil S/A & Indústria & João Fortes Engenharia S. A. & Incor., adm., construção \\
\hline Ampla Energia e Serviços S. A. & Distribuição de energia & JOSAPAR - Joaquim Oliveira S. A. & Indústria \\
\hline Bandeirante Energia S. A. & Transmissão de energia & La Fonte Tel & Participação \\
\hline Bardella S. A. & Fornec. Bens de capital & Louis Dreyfus Commodities Brasil S. A. & Comércio, serv. e ind. \\
\hline BASF AS & Indústria & Leitesol Indústria e Comércio S. A. & Indústria e comércio \\
\hline Bonaire Participações S. A. & Participação & Litel Participações S. A. & Participação \\
\hline BRF S. A. & Holding & Construtora Lix da Cunha S. A. & Incor., adm., construção \\
\hline Companhia Energética de Brasília & Holding & M. Dias Branco & Indústria e comércio \\
\hline Cedro Têxtil & Indústria & Cia Melhoramentos de São Paulo & Indústria \\
\hline Companhia Estadual de Distribuição de Energia & Distribuição de energia & Menezes Côrtes S. A. & Estac. e locação de lojas \\
\hline Companhia Estadual de Distribuição de Energia & Geração e dist. de energia & Metagráfica Iguaçu S. A. & Indústria \\
\hline Centrais Elétricas de Santa Catarina & Holding & Metalfrio Solutions S. A. & Indústria e comércio \\
\hline Centrais Elétricas do Pará & Distribuição de energia & Metanor S. A. - Metanol do Nordeste & Indústria e comércio \\
\hline Celulose Irani S. A. & Indústria & Metisa Metalúrgica Timboense S. A. & Indústria \\
\hline Cemig Telecomunicações S. A. & Infra de rede e/ou serviços & Minasmáquinas S. A. & Comércio \\
\hline Central Geradora Termelétrica Fortaleza S. A. & Produção de energia & Moura Dubeux Engenharia S. A. & Incor., adm., construção \\
\hline Companhia Hidrelétrica do São Francisco & Geração e dist. de energia & Mundial S. A. & Indústria \\
\hline Clariant S. A. & Indústria & Nadir Figueiredo Indústria e Comércio S. A. & Indústria \\
\hline Companhia Energética Ceará - COELCE & Distribuição de energia & Newtel Participações S. A. & Participação \\
\hline Concessionária Rio Teresópolis & Concessionária rodovia & Novartis Biociências S. A. & Indústria e comércio \\
\hline Companhia de Tecidos Norte de Minas & Holding & Conservas Oderich S. A. & Indústria \\
\hline Digitel S. A. & Infra de telecom e/ou serviços & Panatlântica S. A. & Indústria e comércio \\
\hline Dinamica Energia S. A. & Participação & Petróleo Lub do Nordeste S. A. & Indústria \\
\hline Dormer Tools AS & Indústria & Pomifrutas S. A. & Indústria e comércio \\
\hline DSM Produtos Nutricionais S. A. & Indústria & Portobello S. A. & Indústria e comércio \\
\hline EDP Energias do Brasil S. A. & Comércio & Portuense Ferragens S. A. & Comércio \\
\hline Elekeiroz & Indústria e comércio & $\begin{array}{l}\text { Profarma Distribuidora de Produtos Farmacêuticos S. } \\
\text { A. }\end{array}$ & Atacado e varejo \\
\hline Elektro Redes S. A. & Distribuição de energia & Produtos Roche Químicos e Farmacêuticos S. A. & Indústria e comércio \\
\hline Eletrobrás Participações S. A. & Participação & Cia Tecidos Santanense & Indústria \\
\hline
\end{tabular}


Elevadores Atlas Schindler S. A.

Empresa Metropolitana de Águas e Energia S. A.

Empresa Nacional de Comércio Redito e Participações

S.A.

Energisa Mato Grosso Dist. de Energia S. A

Energisa Sergipe Dist. de Energia S. A.

Empresa Energética de Mato Grosso do Sul

Ericsson Telecomunicações S. A.

Eternit

Excelsior Alimentos S. A.

Eztec

Fibam Companhia Industrial

Fibria

Fras-Le S. A.

Gerdau

Metalúrgica Gerdau S. A.

Grazziotin

Grendene

GTD Participações S. A.

Holcim (Brasil) S. A

Iharabras S. A. Indústrias Químicas

Cia Industrial Cataguases

Invepar

Investco S. A.
Comércio, serv, e ind

Produção de energia

Holding

Distribuição de energia

Distribuição de energia

Distribuição de energia

Comércio, serv. e ind.

Indústria e comércio

Indústria

Incor., adm., construção

Indústria

Indústria

Indústria

Indústria

Holding

Atacado e varejo

Indústria

Holding

Comércio, serv. e ind.

Comércio, serv. e ind.

Indústria

Participação

Produção de energia
Santher Fábrica de Papel Santa Therezinha S. A.

Santos Brasil Logística S. A.

Schulz S. A.

SLC Agrícola S. A.

Spal Indústria Brasileira de Bebidas S. A.

Construtora Sultepa S. A.

Swedish Match da Amazônia S. A.

Takata-Petri S. A.

Tekno S. A. Indústria e Comércio

Terminais Portuários Ponta do Félix S. A.

Tim Celular S. A.

Totvs S. A.

SAG do Brasil S. A.

Uptick Participações S. A.

Via Varejo S. A.

Vulcabras S. A.

Weg S. A.

Wembley S. A.

Whirlpool do Brasil Ltda

Whirlpool S. A.

WLM Indústria e Comércio S. A.

Zain Participações S. A.
Indústria

Serviços de logística portuária

Indústria

Indústria e comércio

Indústria e comércio

Incor., adm., construção

Indústria e comércio

Indústria e comércio

Indústria

Serviços de logística portuária

Oper. de serv. telef.

móvel/tv/internet

Consultoria

Prestação de serviços

Holding

Atacado e varejo

Comércio

Participação

Holding

Indústria e comércio

Indústria e comércio

Holding

Participação

Fonte: Demonstrações financeiras divulgadas em jornais de ampla circulação. 
Apêndice I - Estatísticas Comparativas: Empresas com Patrimônio Líquido Menor do que Zero

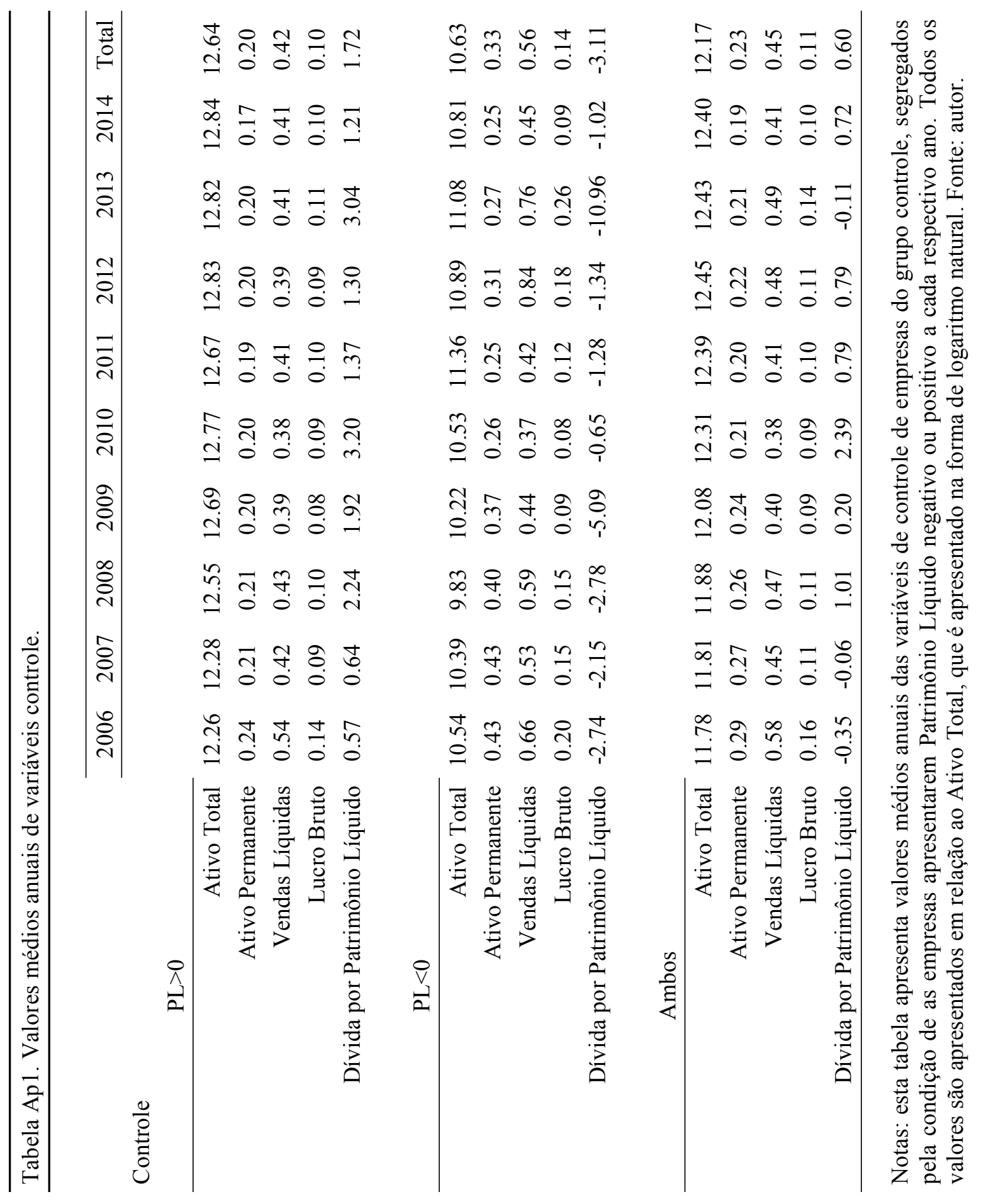




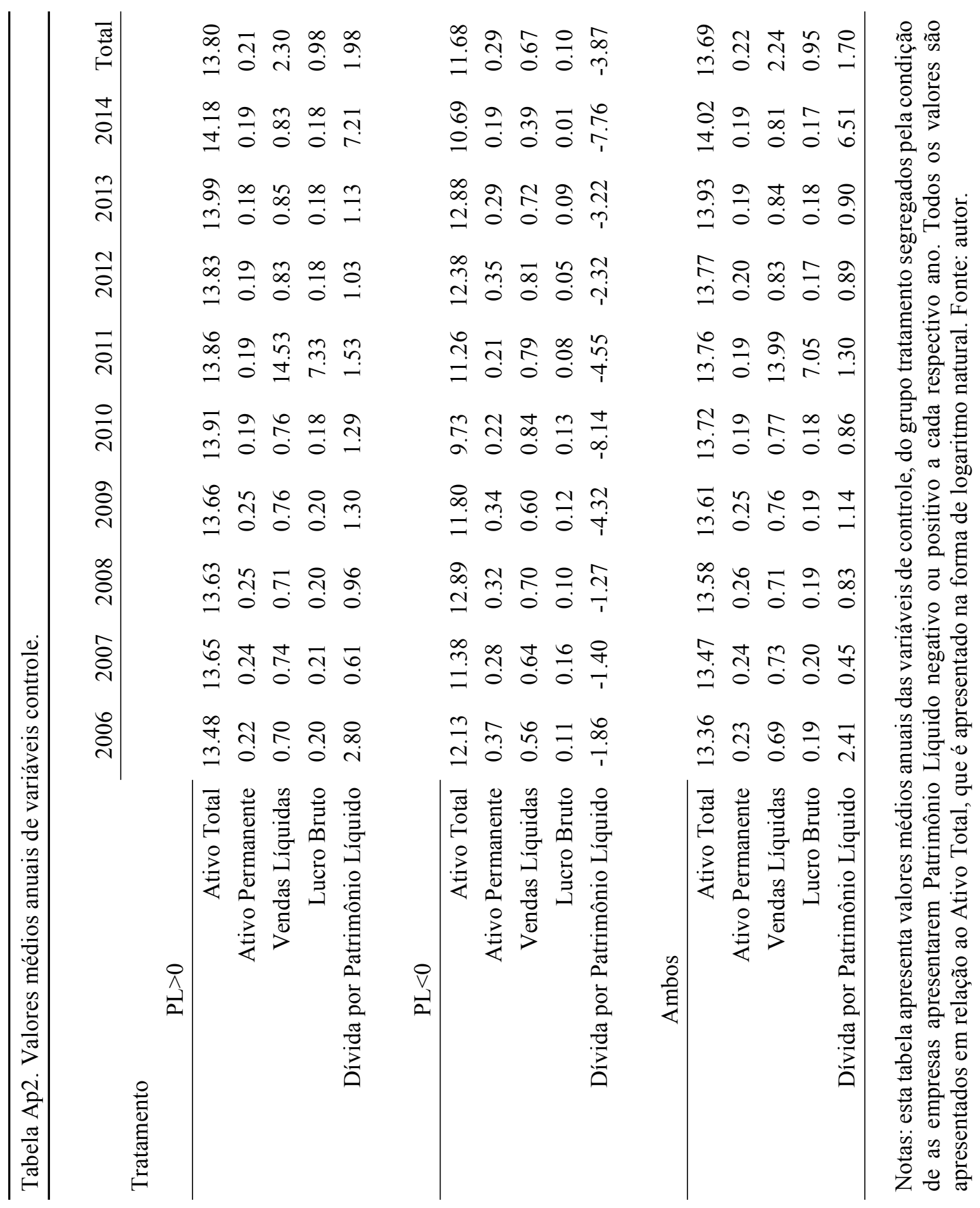


Apêndice II - Valores médios e medianos das variáveis explicativas, antes e após a lei.

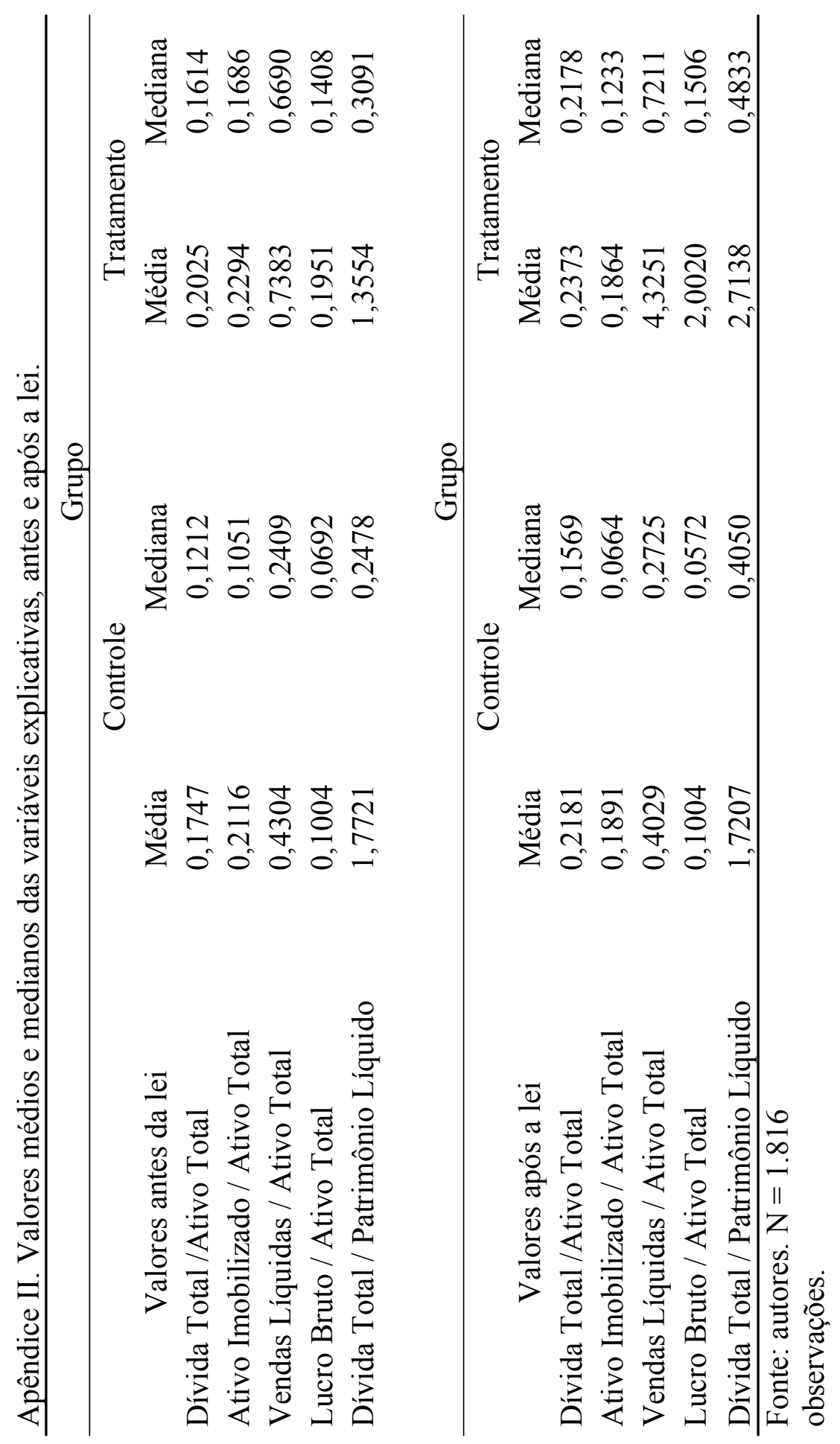


Apêndice III - Coeficientes e erros-padrão da diferença entre os grupos por variável e por período.

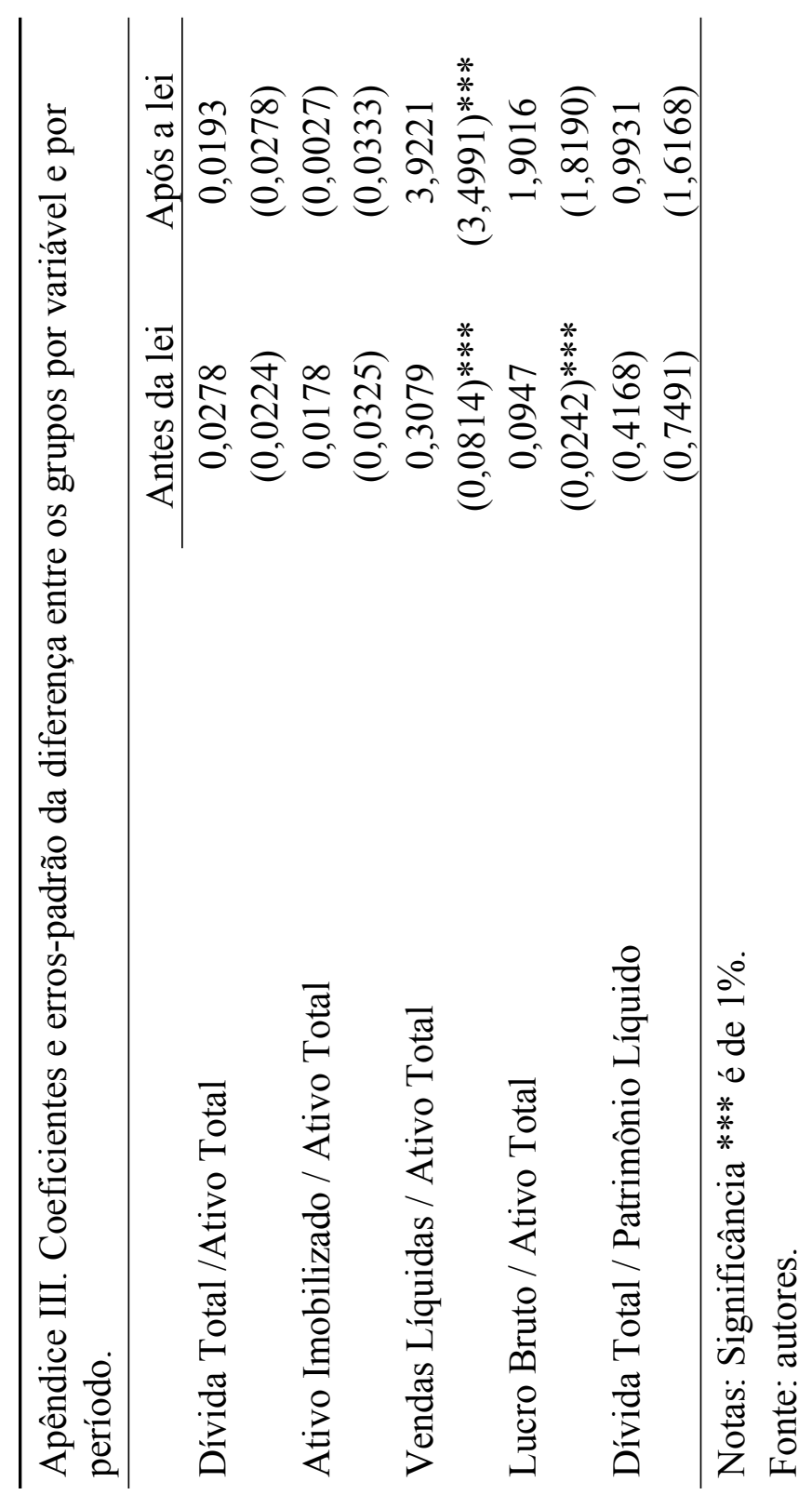


Apêndice IV - Gráfico com valores medianos da variável dependente por ano e grupo.

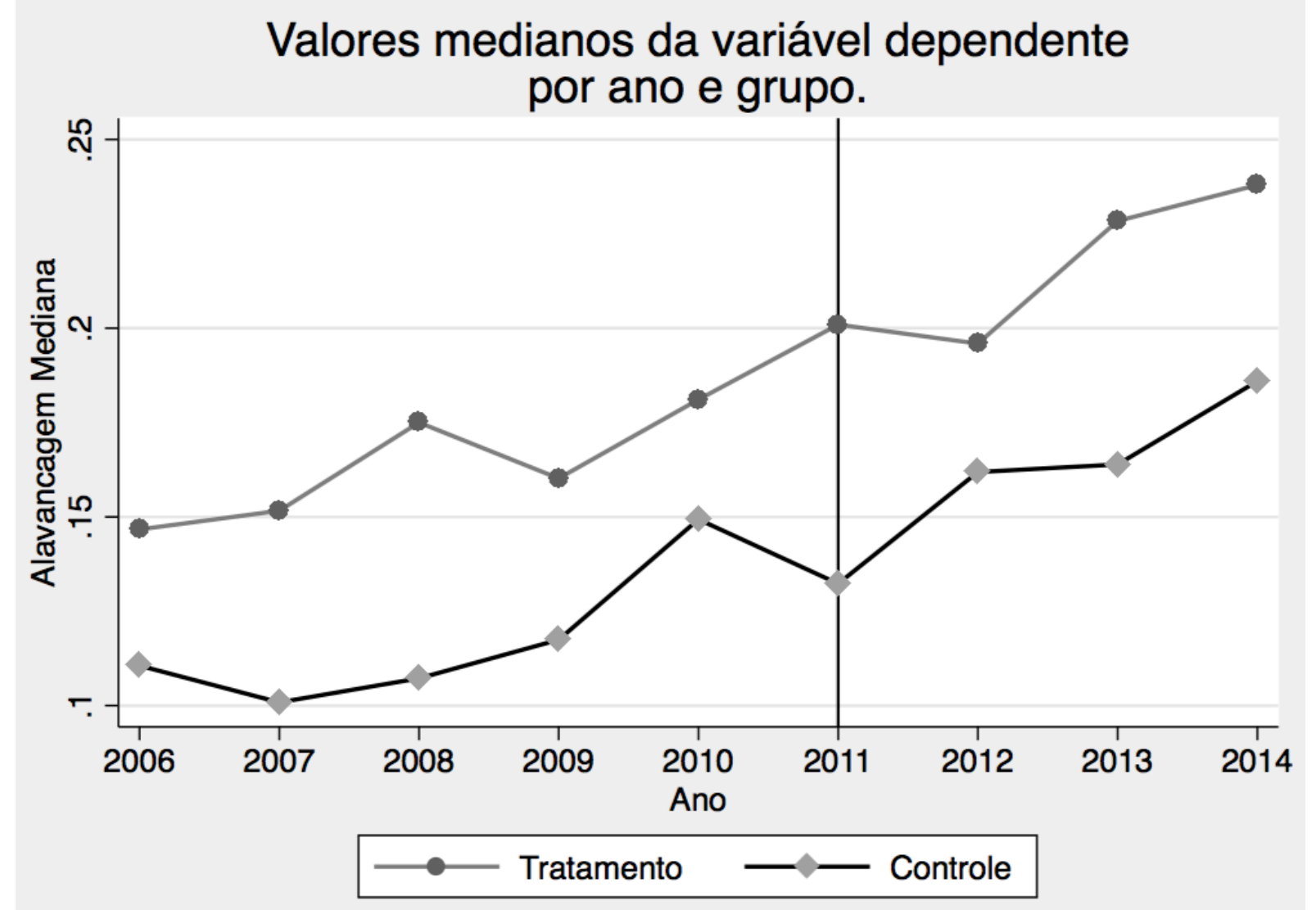

